\title{
Renata Akiyama
}

Análise comparativa da intervenção fonoaudiológica na surdez: com a família ou com os pais?

Dissertação apresentada à Faculdade de Medicina da Universidade de São Paulo para obtenção do título de Mestre em Ciências

Área de Concentração: Fisiopatologia Experimental

Orientadora: Profa. Dra. Ida Lichtig

São Paulo 
Aos meus pais, Julio e Julia, e ao meu irmão Ricardo, pelo apoio constante, pelo incentivo e pelo verdadeiro significado de FAMíLIA

À minha avó Yoshiko, de 93 anos, que me mostra a cada dia o quanto é bom viver Ao meu namorado Daniel, pelo seu amor, sua paciência, compreensão e companheirismo Dedico este trabalho. 
Agradeço

a Deus, por ter me dado a chance de viver, poder estudar e de realizar este trabalho.

À Profa. Dra. Ida Lichtig, orientadora exemplar que me permitiu sonhar e me ajudou a concretizar este sonho. Pessoa maravilhosa que tenho a honra de poder chamar de amiga.

À Fga. Dra. Maria Inês Vieira Couto, pela sua amizade e por ter me ajudado a encontrar a pergunta que me levou a realizar este estudo.

Às Fgas. Dras. Fabíola Mecca e Mariana Gomes, pela amizade, pela presença constante, pelas trocas de informações e pela disponibilidade.

Às Profas. Dras. Renata Mota Mamede Carvallo, Leila Salomão de La Plata Cury Tardivo e Heloísa Szymanski, pelas contribuições valiosas e pelo empenho em me mostrar o caminho a seguir no Exame de Qualificação.

À Profa. Dra. Maria Silvia Cárnio, pelo incentivo constante e pela seriedade com que realiza seu trabalho.

Ao amigo André Luiz Oda, pois talvez sem o seu incentivo inicial, esta pesquisa não existisse.

Aos pais e familiares das crianças surdas atendidas no Laboratório de Investigação Fonoaudiológica em Audiologia Educacional da FMUSP, meus companheiros de trabalho e busca por uma qualidade de vida melhor, por terem aceitado participar deste estudo.

Ao apoio financeiro concedido pela CAPES e ao auxílio pesquisa concedido pela FAPESP, condição essencial para a realização deste estudo.

E a todos que de alguma forma contribuíram para que este estudo pudesse ser concretizado. 
“Daqui a cinqüenta anos não vai importar que tipo de carro você dirigiu, em que tipo de casa você morou, o quanto você tinha na sua conta bancária, ou como suas roupas se pareciam. Mas o mundo será um pouco melhor porque você foi importante na vida de uma criança".

Anônimo

(tradução livre da Renata Akiyama) 


\section{SUMÁRIO}

Lista de tabelas VII

Lista de figuras VII

Lista de gráficos VIII

Resumo IX

Summary $\quad X$

1.Introdução............................................................. 01

1.1. Objetivo............................................................ 06

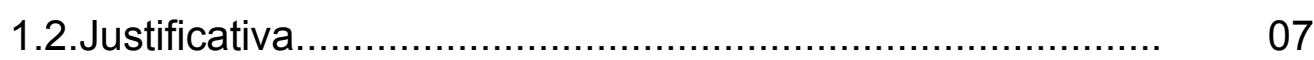

2.Revisão da Literatura............................................. 08

2.1.Família como grupo social........................................... 09

2.2.Aquisição da Língua de Sinais....................................... 10

2.3.Atendimento no Laboratório de Investigação Fonoaudiológica em Audiologia Educacional.................................... 13

2.4.Famílias: modelos de atendimento.............................. 16

3.Metodologia........................................................... 21

3.1.Local................................................................. 22

3.2.Participantes........................................................ 22

3.3.Tipo de pesquisa....................................................... 24

3.4. Recursos materiais................................................... 25

3.5.Elaboração do roteiro de entrevista............................... 25

3.6.Procedimento.......................................................... 28

3.7.Análise dos dados................................................ 30

3.7.1.Análise quantitativa..................................... 31

3.7.2.Análise qualitativa.......................................... 32

4.Apresentação dos dados.............................................. 34

5.Resultados..................................................................... 132

5.1.Resultados referentes a análise quantitativa e qualitativa...... 133

5.1.1.Análise intrafamiliar.......................................... 133 
5.1.2. Análise entre as famílias do grupo direto e grupo indireto.

5.2 Análise comparativa entre os discursos do grupo direto e grupo indireto................................................. 170

6.Discussão

7.Considerações finais e conclusão.......................................... 183

8. Anexo

9.Referências bibliográficas................................................. 187 


\section{LISTA DE TABELAS}

Tabela 3.1.Características dos participantes do grupo direto........ 23

Tabela 3.2.Características dos participantes do grupo indireto..... 24

Tabela 5.1.Concordância intrafamiliar da questão $9 \ldots \ldots \ldots \ldots \ldots \ldots . . . . .133$

Tabela 5.2.Concordância intrafamiliar da questão $10 \ldots \ldots \ldots \ldots \ldots \ldots . . \ldots 133$

Tabela 5.3.Concordância intrafamiliar da questão $11 \ldots \ldots \ldots \ldots \ldots \ldots . . . .134$

Tabela 5.4.Concordância intrafamiliar da questão $12 \ldots \ldots \ldots \ldots \ldots \ldots . . \ldots 134$

Tabela 5.5.Concordância intrafamiliar da questão 13................ 134

Tabela 5.6.Concordância intrafamiliar da questão $14 \ldots \ldots \ldots \ldots \ldots \ldots . . \ldots 135$

Tabela 5.7.Concordância intrafamiliar da questão $15 \ldots \ldots \ldots \ldots \ldots \ldots \ldots . . . . . .135$

Tabela 5.8.Concordância intrafamiliar da questão 16.................. 135

Tabela 5.9.Concordância intrafamiliar da questão $17 \ldots \ldots \ldots \ldots \ldots \ldots .136$

Tabela 5.10.Concordância intrafamiliar da questão $18 \ldots \ldots \ldots \ldots \ldots \ldots 136$

\section{LISTA DE FIGURAS}

Figura 3.1.Fluxograma dos passos do estudo 33 


\section{LISTA DE GRÁFICOS}

Gráfico 5.1Gráfico de concordância intrafamiliar das respostas dadas. 136

Gráfico 5.2.Porcentagem das respostas dadas a questão 9 pelo grupo direto. 138

Gráfico 5.3.Porcentagem das respostas dadas a questão 9 pelo grupo indireto........139

Gráfico 5.4.Porcentagem das respostas dadas a questão 10 pelo grupo direto..........141

Gráfico 5.5.Porcentagem das respostas dadas a questão 10 pelo grupo indireto......142

Gráfico 5.6.Porcentagem das respostas dadas a questão 11 pelo grupo direto.........143

Gráfico 5.7.Porcentagem das respostas dadas a questão 11 pelo grupo indireto......144

Gráfico 5.8.Porcentagem das respostas dadas a questão 12 pelo grupo direto..........146

Gráfico 5.9.Porcentagem das respostas dadas a questão 12 pelo grupo indireto......147

Gráfico 5.10.Porcentagem das respostas dadas a questão 13 pelo grupo direto.......149

Gráfico 5.11.Porcentagem das respostas dadas a questão 13 pelo grupo indireto....150

Gráfico 5.12.Porcentagem das respostas dadas a questão 14 pelo grupo direto........152

Gráfico 5.13.Porcentagem das respostas dadas a questão 14 pelo grupo indireto....153

Gráfico 5.14.Porcentagem das respostas dadas a questão 15 pelo grupo direto.......155

Gráfico 5.15.Porcentagem das respostas dadas a questão 15 pelo grupo indireto....157

Gráfico 5.16.Porcentagem das respostas dadas a questão 16 pelo grupo direto.......158

Gráfico 5.17.Porcentagem das respostas dadas a questão 16 pelo grupo indireto....160

Gráfico 5.18.Porcentagem das respostas dadas a questão 17 pelo grupo direto........161

Gráfico 5.19.Porcentagem das respostas dadas a questão 17 pelo grupo indireto....162 


\section{Resumo}

Akiyama, R. (2006) Análise Comparativa da Intervenção Fonoaudiológica na Surdez: Com a Familia ou com os Pais? [Dissertação] São Paulo: Faculdade de Medicina, Universidade de São Paulo.

A confirmação da surdez de uma criança é muito traumatizante para os pais ouvintes e causa grande impacto no sistema familiar, rompendo-se as expectativas e alterando o relacionamento afetivo, social e a comunicação da família com essa criança. A criança surda, devido ao déficit auditivo, terá dificuldades em ouvir os sons da fala e do meio ambiente impossibilitando-a de uma aquisição espontânea e efetiva da língua oral, mas sua comunicação poderá ser efetiva através da língua de sinais. Por se tratar de famílias ouvintes com crianças surdas nas quais há uma barreira na comunicação e conseqüentemente uma diminuição na interlocução entre os familiares e nas oportunidades sociais e de escolarização dessas crianças, o Programa do Laboratório de Investigação Fonoaudiológica em Audiologia Educacional (LIFAE) do Curso de Fonoaudiologia da Faculdade de Medicina da Universidade de São Paulo oferece as seguintes atividades: terapia fonoaudiológica individual, oficinas de língua de sinais e de língua oral para as crianças surdas, oficinas de língua de sinais para os familiares ouvintes, grupo de suporte aos pais e/ou familiares ouvintes. Este estudo tem como objetivo verificar se a participação de um familiar ouvinte no Programa gera mudanças no comportamento comunicativo das famílias atendidas. Para isso foram entrevistadas 10 famílias sendo que seus membros foram divididos em dois grupos: participantes diretos e participantes indiretos do Programa. Os dados foram tratados quantitativamente através da análise percentual e qualitativamente, através da transcrição e textualização das entrevistas e da elaboração do discurso do Sujeito Coletivo. Os resultados indicaram que os participantes diretos do Programa demonstraram ter um envolvimento maior e uma melhor percepção da vida da criança surda. As mudanças relatadas nos depoimentos mostraram alterações na dinâmica familiar, ou seja, a comunicação e a interação familiar se modificaram, gerando uma melhora no relacionamento entre os seus membros e na aceitação da surdez, indicando que o Programa é eficaz na intervenção fonoaudiológica a crianças surdas e seus familiares ouvintes.

Descritores: surdez, família, fonoaudiologia, linguagem de sinais 


\section{Summary}

Akiyama, R.(2006) A comparative analysis of the speech and hearing intervention program for deaf children: with their family or with their parents? [Dissertação] São Paulo: Faculdade de Medicina, Universidade de São Paulo.

The confirmation of a child's deafness is very traumatic for hearing parents and it causes a great impact on the family system, breaking the expectation and altering the affective, social and communication relationship between the deaf child and his family. The deaf child due to the hearing impairment will have difficulties to hear speech and environmental sounds depriving him of a spontaneous and effective oral language acquisition. However his communication might be effective by using sign language. There is a communication barrier which reduces family's interactions, social and educational opportunities in hearing families with deaf children. Based on these facts the Educational Audiology Service (EAS) of University of São Paulo offers an intervention program which comprises: speech therapy, sign and oral language workshops for deaf children, sign language workshops for hearing parents and a parental support group. The aim of this study is to verify whether the participation of a hearing member in the EAS Program generates communication changes in the hearing families who attend the Program. Ten families were interviewed and their members were divided in two groups: direct and indirect participants in the Program. The data was treated quantitatively by percentage analysis and qualitatively through transcription, textualization and the elaboration of "Discurso do Sujeito Coletivo". The data showed that direct participants had a better relationship and perception on deaf child's life. The reported changes indicate alterations in the families' dynamics, i.e, familiar communication and interaction were changed leading to an improvement in members relationship and acceptance of deafness, showing that the Program is efficient as a speech and hearing intervention for deaf children and their hearing families.

Descriptors: deafness, family, speech, language and hearing sciences, sign language 
1. Introdução 
O nascimento de uma criança é um momento de felicidade na maior parte das famílias, não só pelo fato da inclusão de um novo membro, mas também pela segurança de uma continuidade familiar (Lane et al, 1996).

Entende-se por família, um grupo de pessoas que vive em uma estrutura hierarquizada, convivendo com uma proposta de ligação afetiva (homem, mulher e filhos biológicos, mulher, afilhada e filhos adotivos ou qualquer outra combinação) duradoura, podendo ou não ser definitiva, que inclui relações de cuidados entre os adultos e deles para com as crianças e idosos que aparecerem neste contexto (Gomes, 1988).

Cada pessoa, além da herança genética é herdeira do simbólico da relação pai-mãe-filho que está no imaginário dos pais antes mesmo do nascimento. Cada criança, segundo Formigoni (2003), nasce com uma missão imaginária que será moldada, confrontada e reformulada de acordo com os acontecimentos entre os pais e essa criança. A expectativa de qualquer família é que seu filho tenha uma vida melhor do que a sua e a crença de que ele irá se beneficiar com as suas experiências contribui para o fortalecimento da unidade familiar (Lane et al, 1996).

Essa expectativa e imaginário é o que Szymanski (2001) denomina de família pensada, que leva em consideração a idealização pessoal, o que se espera socialmente e o que é transmitido pela mídia ou instituições, que difere da família vivida onde os membros criam formas de viver em família diferentes 
do modelo, agindo naturalmente, podendo ou não estar em acordo com a família pensada.

Porém, quando uma criança surda faz parte de uma família ouvinte, o que ocorre em 92\% a 97\% dos casos (Balieiro \& Ficker, 1997; Lichtig et al, 2004a), ou seja, quando um filho é diferente daquele idealizado, implica em conflitos pessoais e interpessoais (Holzheim et al, 1997) gerando ações diferentes das prescritas socialmente e são em geral muito dolorosas (Lane et al, 1996).

A suspeita de que há alguma coisa diferente com a criança, é levantada inicialmente pela família e geralmente ocorre por volta dos doze aos dezoito meses de idade quando as crianças não apresentam as primeiras palavras, porém segundo Nakamura et al (2000) em 1986, na cidade de São Paulo, a idade média diagnóstica variava de oito a quarenta e cinco meses de idade.

Essa lentidão no diagnóstico pode estar relacionada com o baixo nível sócio econômico e cultural dos pais, o que dificulta o acesso a um profissional especializado. Em muitas ocasiões profissionais de saúde têm orientado às famílias que esperem um tempo a fim de verificar se a criança, espontaneamente, supera suas dificuldades (Nakamura et al., 2000).

O momento em que se confirma o diagnóstico da surdez é muito traumatizante para os pais ouvintes e é normalmente caracterizado por um estado de choque, causando grande impacto no sistema familiar. Há rupturas 
nas expectativas, alterações no relacionamento afetivo, social e de linguagem da família com a criança (Holzheim, et al., 1997). Os anseios mudam e muitas vezes estes pais se sentem culpados por terem gerado uma criança com ‘defeito' (Lane et al, 1996) ou por terem sido responsáveis pela seqüela de alguma doença contraída pela criança. Outros sentimentos que emergem são em geral, a raiva, a culpa, a depressão e a negação da surdez.

Vivenciar todos esses momentos leva os pais ouvintes a uma reavaliação dos valores e a uma reestruturação da sua vida pessoal e familiar a fim de se adaptarem ao novo filho e à surdez (Holzheim et al, 1997). Os pais podem viver uma fase de adaptação até que sintam a necessidade de lidar com os sentimentos mais sinceros e íntimos. Encarar esses sentimentos é tarefa difícil que exige força e elaboração de luto, honestidade, inteligência e sensibilidade para lidar de uma maneira mais natural com a surdez, mas depois disso, a recompensa será bem maior (Bergman, 2001).

É preciso re - gestar essa criança, deixá-la nascer e humanizá-la, não considerá-la apenas como uma orelha que não escuta e precisa ser consertada (Formigoni, 2003). É necessário que a família tenha um tempo para "re conhecer" sua criança como uma criança surda (Mahshie, 1995) e somente os pais têm a possibilidade de fazer dessa criança um outro ser humano, de darIhe um nome e uma filiação (Formigoni, 2003). 
Nessas famílias, de pais ouvintes e crianças surdas, há uma barreira na comunicação em razão da baixa de audição da criança gerando assim uma restrição nas oportunidades de interlocução (Balieiro \& Ficker, 1997), dificuldades sociais e de escolarização (Roslyng - Jensen, 1997).

A ausência do som, no vínculo mãe e filho, impossibilita o bebê surdo de receber o componente melódico e afetivo da voz da mãe. A criança surda registrará, então, os afetos e carinhos das pessoas que a rodeiam, a partir das suas expressões, toques e carícias (Bergman, 2001) e a comunicação poderá ser efetiva através de outra modalidade de língua, a viso - espacial, para a aprendizagem e reconhecimento de mundo (Quadros, 1997; Kozlowski, 1998).

Com o reconhecimento de que a Língua de Sinais é a língua natural do surdo, este passou a ser visto como alguém que tem uma forma própria de se comunicar, alguém com uma língua diferente e não desviante (Cárnio, 1998) e uma cultura particular, o que assegura a aquisição e o desenvolvimento da linguagem, resultando em uma auto - estima positiva.

Através da Língua de Sinais a criança surda poderá desenvolver a comunicação, resgatar a afetividade com a mãe, construir significados e se situar no mundo (Bergman, 2001).

Em razão de todos os aspectos levantados e por ser o profissional fonoaudiólogo, na realidade brasileira, o primeiro profissional a ser procurado 
assim que a família recebe o diagnóstico da surdez, é de suma importância que um atendimento fonoaudiológico seja oferecido, o mais cedo possível, a essas crianças e a seus familiares.

\subsection{Objetivo}

Este estudo tem por objetivo verificar se a participação de um familiar ouvinte no Programa de Intervenção Fonoaudiológica desenvolvido no Laboratório de Investigação Fonoaudiológica em Audiologia Educacional (LIFAE) do Curso de Fonoaudiologia da USP gera mudanças no comportamento comunicativo das famílias atendidas.

\section{Objetivos específicos}

Os objetivos específicos deste estudo são:

* Verificação do comportamento comunicativo dos participantes do Grupo de Pais, a partir do roteiro elaborado. Este será, a partir de agora, identificado com o Grupo Direto. Os participantes deste grupo são aqueles que comparecem às atividades do Programa e participam sistematicamente das reuniões do Grupo de Pais, recebendo diretamente as informações e orientações, sejam eles pais, mães, avós ou tias das crianças atendidas no LIFAE.

* Verificação do comportamento comunicativo dos familiares que convivem com a criança surda, porém não participam sistematicamente do 
Grupo de Pais, utilizando o mesmo roteiro. Este Grupo será denominado Grupo Indireto. Os participantes deste grupo são aqueles que não comparecem sistematicamente às atividades do Programa, a não ser quando convidados.

* Verificação da concordância das respostas entre os membros da mesma família.

* Correlação entre as respostas dadas pelos dois grupos.

\subsection{Justificativa}

Este trabalho justifica-se pois na revisão da literatura não foi encontrado nenhum estudo que levantasse as opiniões de familiares que não participam diretamente de uma intervenção fonoaudiológica com famílias de crianças surdas.

Por se tratar de um Programa inovador, a saber, uma abordagem bilíngüe com participação interdisciplinar, fonoaudiólogos, alunos de graduação em fonoaudiologia, psicólogos, pedagoga e instrutora surda, é importante detectar o alcance do que é realizado no ambiente clínico para os outros membros da família, pois a criança surda convive com todos os familiares, os que se responsabilizaram por comparecer ao Programa e também por aqueles que não podem comparecer à Clínica. 
2. Revisão da literatura 


\subsection{Família como grupo social}

O ser humano é social e gregário por natureza e desde o nascimento participa de diferentes grupos em uma dialética constante pela busca de identidade individual e a necessidade de identidade grupal. Este processo inicia-se pela família, que apesar de não ser o único canal pelo qual se trata a questão da inserção social, tende a ser o primeiro grupo responsável por essa tarefa de socialização (Vitale, 1995).

A família é a responsável pela transformação do homem em um ser social típico, ou seja, quando nasce ele é apenas um organismo, um ser biológico e é a família que vai prepará-lo para a vida organizada da sociedade em que vive (Gomes, 1994; Mello, 2002), promovendo a formação básica de sua identidade

e personalidade (Gomes, 1992). A socialização inicia-se em casa onde a criança convive com os pais, avós, irmãos e vai se ampliando e renovando durante toda a vida, com a constituição de grupos associativos, profissionais e novas famílias (Zimerman, 1997).

A descoberta de que os primeiros anos de vida de uma criança são cruciais para o seu desenvolvimento emocional posterior, focalizou a família como sendo produtora potencial de pessoas saudáveis e emocionalmente estáveis ou como núcleo produtor de inseguranças, desequilíbrios e de desvios de comportamento (Szymanski, 1995), pois o desenvolvimento psico - social e emocional da criança está intimamente relacionado às vivências familiares. 
Quanto mais produtivo e seguro for o ambiente familiar, mais estável, equilibrada e feliz será a criança (Lima et al, 1999).

O ambiente familiar é propicio para oferecer inúmeras atividades que desenvolvem as habilidades cognitivas e sociais, oferecendo oportunidades a todos os envolvidos, sejam eles crianças ou adultos. Pois é a transmissão da herança cultural e familiar que possibilitará a inserção no mundo social, para que se possa atuar nele. Essas práticas educativas envolvem conhecimentos e saberes, mesmo não sendo sistematizados (Szymanski, 2000).

\subsection{Aquisição da Língua de Sinais}

Devido ao déficit sensorial a criança, com perda auditiva severa ou profunda, tem dificuldades em ouvir os sons da fala e do meio e isso a impede de tomar consciência dos sons produzidos por ela mesma e pelas outras pessoas, impossibilitando-a de uma aquisição espontânea e efetiva da língua oral, dentro do contexto de suas relações (Bergman, 2001). Decorre que desde a fase de lactente, o balbucio não é tão rico em entonações como na criança ouvinte (Nakamura et al., 2000). Existem limitações biológicas reais para que a maioria das crianças surdas não adquira a língua oral pelos processos interacionais normais (Mahshie, 1995). Dessa forma, a privação ao acesso da palavra empobrece a simbolização e deteriora a construção de significados. Como não escuta, a criança não associará os sons produzidos por ela mesma 
como comunicação, desconhecendo desde cedo o valor lingüístico do som (Bergman, 2001).

A aquisição da Língua Oral pela criança ouvinte acontece espontaneamente em uma situação contextualizada e motivadora (Cárnio et al., 2000). Desde bebê, ela vai diferenciando e qualificando suas experiências, nomeando a realidade externa e interna (Bergman, 2001) e à medida que o adulto valoriza, incentiva e reforça as imitações, ele modela o repertório fonético do bebê (Aimard, 1998).

De forma análoga, crianças surdas, filhas de pais surdos, recebem um 'input' lingüístico adequado e a aquisição da Língua de Sinais ocorre de modo semelhante à aquisição da Língua Oral pelas crianças ouvintes (Quadros, 1997), pois pais surdos comunicam-se naturalmente com seus filhos surdos desde o nascimento (Lane, et al., 1996). Deste modo, a Língua de Sinais possibilita que o surdo desenvolva linguagem e comunicação (Sánchez, 1993), dando-lhe acesso real ao desenvolvimento cognitivo, afetivo, social e emocional. Além disso o letramento pode se iniciar antes da criança surda freqüentar a escola, como acontece com as crianças ouvintes (Sánchez, 1993, Mahshie, 1995, Fernandes, 2000).

Com isso o surdo pode, então, desenvolver a sua identidade e garantir sua socialização (Moura et al., 1997). Suas potencialidades podem ser 
totalmente desenvolvidas desde que seus direitos lingüísticos sejam respeitados (Kozlowski, 1998).

A Língua de Sinais possibilita aos surdos sua inserção no funcionamento lingüístico discursivo da língua e assim podem ser constituídos como autores de seu dizer e não apenas como repetidores de padrões aprendidos (Pereira, 2000). Criar um ambiente de confiança e de linguagem acessível para a criança surda é um movimento efetivo dos pais ouvintes, da tristeza para o reconhecimento de que está tudo bem com seu filho surdo (Mahshie, 1995).

Segundo um estudo relatado por Bergman (2001) após o primeiro acesso à língua de sinais, as crianças surdas melhoraram até em sua fisionomia, tornaram-se mais felizes, seus olhos passaram a brilhar, despertaram para a vida e para o mundo, por poderem entender e sentirem-se entendidas.

Em países como a Suécia e a Dinamarca onde o sistema educacional instituído é para todos, segundo Mahshie (1995), o objetivo para a maioria das crianças surdas é que a língua não adquirida naturalmente vai ser aprendida como $2^{\mathrm{a}}$ língua quando a criança estiver desenvolvida, pronta cognitivamente e interessada (Mahshie, 1995) e portanto a primeira língua a ser adquirida será a Língua de Sinais de modalidade viso-espacial, a qual poderá ser adquirida ou aprendida naturalmente, ou seja sem limitações e barreiras sensoriais. Porém em países que não existe tal política governamental, a decisão sobre qual deve 
ser a primeira língua da criança surda recai sobre os pais, que normalmente têm que fazer a escolha entre a oralidade e uma educação bilíngüe.

\subsection{Atendimento no Laboratório de Investigação Fonoaudiológica} em Audiologia Educacional (LIFAE)

As crianças surdas atendidas no LIFAE do Curso de Fonoaudiologia da Faculdade de Medicina da Universidade de São Paulo estão inseridas em famílias ouvintes e na sua maioria não tem fluência na Língua de Sinais. Por ser a Língua de Sinais fundamental para o desenvolvimento cognitivo e emocional da criança surda, em 1996 o LIFAE, que faz parte da área de saúde, iniciou pesquisas voltadas ao bilingüismo para a educação do surdo. Desde então, o LIFAE tem preconizado o aprendizado das duas línguas, a Língua Brasileira de Sinais - LIBRAS e o Português em sua modalidade oral, sendo que a sua modalidade escrita deverá ser contemplada no âmbito da Educação, ou seja, com a freqüência da criança à escola.

O LIFAE está estruturado da seguinte forma:

- Oficinas em LIBRAS, mediada por um adulto surdo às crianças surdas, visando o aprendizado de LIBRAS com o desenvolvimento da linguagem e cognição das crianças surdas, além de garantir o contato de crianças surdas com surdos adultos que é absolutamente essencial para que se desenvolva um senso saudável de identidade como pessoa surda (Mason, 1991). 
* Oficinas em LIBRAS, ministrada por um adulto surdo aos pais e/ou responsáveis ouvintes, visando o contato inicial com a LIBRAS.

* Grupo de Suporte aos Pais e/ou familiares ouvintes coordenado por fonoaudiólogas e assessorado por uma psicóloga.

* Terapia fonoaudiológica individual, cujo objetivo é propiciar o aprendizado da Língua Oral como $2^{\mathrm{a}}$ língua da criança surda, com orientações individuais aos familiares.

* Oficinas em Língua Oral e em grupo visando a socialização e o desenvolvimento da oralidade da criança surda.

A intervenção fonoaudiológica na surdez inclui vários procedimentos para o desenvolvimento das habilidades comunicativas, auditivas e lingüísticas e a participação da família nesse processo é fundamental para garantir o sucesso do seu desenvolvimento (Lichtig et al, 2003; Cárnio \& Couto, 2004). Não é possível, segundo Holzheim et al. (1997), atender adequadamente uma criança surda se não for incluído em seu planejamento um trabalho centrado na orientação familiar.

Em um estudo realizado por Tardivo et al. (1999) com crianças surdas, observou-se que essas crianças mesmo tendo dificuldades na comunicação oral, possuem um mundo mental rico que pode se manifestar. Através de desenhos pôde-se perceber que, apesar de certa imaturidade, há diferentes graus de estruturação e organização da personalidade e que são capazes de mostrar desejos e necessidades de contato, além de expressar suas fantasias, 
portanto os ajustes maiores devem ser da família e não da criança surda (Mahshie, 1995).

Muitos dos serviços para as pessoas portadoras de necessidades especiais estão orientados apenas para as necessidades do próprio paciente. Assim a responsabilidade do profissional é apenas informar aos pais sobre o progresso de seu filho, porém o que se vê hoje é que o envolvimento familiar e o cuidado com a criança são cruciais (Balasundaram, 1995).

Nenhum pai ouvinte ou nenhuma família ouvinte nasceu pronto para ser pai ou família de crianças ouvintes ou surdas. Os pais aprendem a ser pais quando passam pela experiência, e é na experiência de serem pais de crianças surdas que eles encontrarão respostas às suas angústias (Bergman, 2001).

Os pais têm o direito de experimentar a descrença, o choque, a culpa, a rejeição e o ódio pela criança e por si mesmos, bem como a vergonha, o ressentimento, a negação, o sentimento de incompetência e a responsabilidade são emoções que exigem uma atitude compreensiva para que possam ser elaboradas (Buscaglia, 1993, Luterman, 1999). Após a vivência e conscientização desse período, as informações poderão ser melhor aceitas e absorvidas e o sucesso será ainda maior dependendo da boa relação entre pais e profissionais. 


\subsection{Famílias: modelos de atendimento}

Segundo o estudo de Dunst, et.al., 2002, existem quatro tipos de modelos de atendimentos com famílias: os centrados nos profissionais, os associados às famílias, os focados nas famílias e os centrados nas famílias.

1 - O modelo centrado nos profissionais vê os profissionais como "experts" na maioria das questões envolvendo a criança e a família. Os profissionais dão pouco ou nenhum crédito às opiniões ou pontos de vista da família. As decisões sobre as intervenções são feitas pelos profissionais e a família é apenas informada sobre o que os profissionais acham ser o mais apropriado.

2 - O modelo associado à família vê as famílias como minimamente capazes. As famílias funcionam como agentes para realizar o que foi prescrito pelos profissionais.

3 - O modelo focado na família vê a família como capaz de tomar suas decisões, porém as opiniões são geralmente limitadas ao que os profissionais acham ser os melhores recursos, suportes e serviços. Uma vez feita a escolha, os profissionais assumem a responsabilidade de prover a família com a assistência e os conselhos sobre como a intervenção deve ser implementada e conduzida.

4 - O modelo centrado na família vê os profissionais e a família como parceiros. Os profissionais vêem a família como capaz de fazer suas escolhas, de tomar decisões e de agir de acordo com elas. 
O modelo que dá base às reuniões com o Grupo de Suporte aos Pais e/ou familiares ouvintes do LIFAE, é o modelo de atendimento centrado na família. As reuniões são intermediadas por duas fonoaudiólogas e uma psicóloga e seu principal objetivo é o estabelecimento de uma comunicação eficaz entre os familiares ouvintes e seus filhos surdos, incentivando o aprendizado da Língua Brasileira de Sinais e melhorando as habilidades de comunicação em geral (Lichtig et al., 2004 b).

O trabalho multidisciplinar com o Grupo de Suporte aos Pais e/ou Familiares ouvintes do LIFAE é um espaço para os participantes, um tempo para eles mesmos, onde cada um tem a oportunidade de opinar, questionar e chegar a conclusões, visando seu empoderamento a partir da aquisição de maiores conhecimentos que vão de encontro às necessidades de seus filhos (Skogmo, 1995).

O Grupo de Pais do LIFAE só tem sentido de ser por se tratar de famílias ouvintes com crianças surdas, pois como dito antes, a barreira na comunicação implica na diminuição de interlocução entre os familiares e nas oportunidades sociais e de escolarização das crianças surdas. O mesmo não ocorreria se os pais fossem surdos, pois pais surdos expõem seus filhos surdos a um ambiente que naturalmente depende de pistas visuais. Suas casas já funcionam como ambientes que precisam da visão como a principal fonte de aprendizado e desenvolvimento. Pais surdos estão aptos a se comunicar com seus filhos surdos imediatamente (Lane, et al., 1996). 
O trabalho em grupo, com familiares ouvintes, proporciona mudanças emocionais favoráveis, diminui a ansiedade e aumenta a auto-estima, refletindo de maneira positiva e direta em seus filhos surdos (Funk \& Machado, 1995). Os resultados do estudo de O'Brien (2002) mostram que é importante criar oportunidades para os pais se reunirem, para compartilhar histórias e experiências e para dar e receber suporte um do outro.

O grupo de pais do LIFAE está relacionado com a comunicação aonde, muitas vezes, o emocional vem a tona, porém esses aspectos não são trabalhados terapeuticamente. Caso se faça necessário essas questões são encaminhadas a um atendimento psicológico individual.

Os temas e assuntos discutidos nas reuniões do Grupo de Pais estão baseados nos módulos utilizados durante a pesquisa conveniada com a Universidade de Londres e City University (Woll et al., 1995) e descritas por Mecca et al. (2004), sendo eles: partilhando expectativas, linguagem, troca de turno, toque, contato de olho, interação familiar, leitura e escrita. Porém com o passar do tempo outros temas são incorporados e na maior parte das vezes eles surgem a partir das dificuldades e conquistas relatadas pelos próprios participantes. Segundo O'Brien (2002) os pais devem ter a oportunidade e a responsabilidade para decidir quais temas, assuntos e sentimentos são importantes de serem identificados e de serem explorados. Davis \& Rushton (1991) apontam que para uma intervenção ser bem sucedida é de suma 
importância que o profissional saiba ouvir e ajudar os pais a adaptarem suas necessidades bem como as incapacidades de seus filhos.

Em algumas situações, um assunto específico sobre uma das crianças aparece e nesse momento, o responsável é encorajado a pensar em soluções para o seu problema, enquanto que os outros que já vivenciaram situação semelhante são incentivados a relatar suas experiências. Um grupo assim cria uma relação próxima e confidente o que torna possível a discussão de vários assuntos relacionados com a interferência da comunicação no dia a dia destes familiares (Lichtig et al., 2004 a). Segundo Holzheim et al (1997), se o familiar tiver a oportunidade de expressar seus medos e suas aflições abertamente, maior será a chance dele alcançar um tipo de conforto duradouro que surge nele próprio.

Os integrantes de um grupo trazem consigo o seu mundo interno, conforme as histórias e as relações pessoais, profissionais e comunitárias vividas por cada um, que determinará a forma de se relacionar com o mundo externo.

Ao formar um grupo, cada pessoa estabelece novas relações que passam a integrar seu mundo interno, agindo e esperando reações, assim torna-se fundamental a comunicação e o diálogo em torno dos seus desejos e anseios (Guimarães, 1995). Amizades são criadas em um clima de 
compromisso, simpatia e humor, eles dão forças e esperanças uns aos outros (Holzheim et al., 1997).

Além disso, o trabalho em grupo é uma boa forma de lidar com as resistências das famílias, principalmente no que diz respeito à aceitação da surdez e de uma nova modalidade de língua, a Língua de Sinais, que não faz parte da rotina de vida da família ouvinte (Lichtig et al., 2004 a). Segundo Kellam (2001) o grupo é utilizado para normatizar comportamentos e conceitos, o que gera segurança, uma vez que o encontro entre familiares que compartilham da mesma problemática, cria um espaço que permite um rico intercâmbio a partir da solidariedade e da ajuda mútua (Ravazzola et al, 1997). Normalmente as pessoas se beneficiam ao perceber que outros passam por dificuldades semelhantes às suas, possibilitando uma melhor compreensão frente aos problemas que surgem aprendendo também diferentes estratégias facilitadoras (Souza \& Wieselberg., 1997).

É importante dar aos pais ouvintes, confiança na sua vontade e habilidade de se fazer os ajustes precisos e reconhecer seu importante papel. Para isso é necessário provê-los com uma orientação positiva (Mahshie, 1995). Não se pode dar uma informação parcial, tudo precisa ser feito de maneira direta e honesta, com informações reais (Holzheim, et al., 1997), assim como deve se dar suporte e o treino necessário para que façam escolhas conscientes. Essas pessoas merecem confiança e ajuda para que possam exercer seu papel tradicional, o de serem pais (Mahshie, 1995). 
3. Metodologia

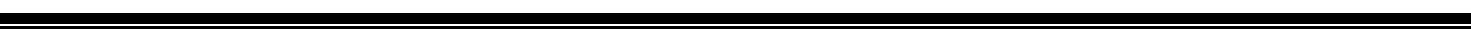




\subsection{Local}

Este estudo foi desenvolvido no Laboratório de Investigação Fonoaudiológica em Audiologia Educacional (LIFAE), situado no Centro de Docência e Pesquisa em Fonoaudiologia do Curso de Fonoaudiologia do Departamento de Fisioterapia, Fonoaudiologia e Terapia Ocupacional da FMUSP.

\subsection{Participantes}

Para esta pesquisa foram estudados os depoimentos de 22 membros de 10 famílias atendidas no LIFAE, distribuídas em dois grupos:

* Grupo Direto - $(n=11)$ participantes diretos do Grupo de Pais do Laboratório de Investigação Fonoaudiológica em Audiologia Educacional (LIFAE) do Curso de Fonoaudiologia da FMUSP.

* Grupo Indireto - $(n=10)$ participantes indiretos do Grupo de Pais do Laboratório de Investigação Fonoaudiológica em Audiologia Educacional (LIFAE) do Curso de Fonoaudiologia da FMUSP. 
Tabela 3.1 Características dos participantes do grupo direto ${ }^{1}$

\begin{tabular}{|c|c|c|c|c|c|c|}
\hline Participantes & $\begin{array}{l}\text { Idade } \\
\text { em anos }\end{array}$ & sexo & Parentesco & Escolaridade & $\begin{array}{l}\text { Pacientes / } \\
\text { idade }\end{array}$ & Grupo familiar \\
\hline Amanda & 22 & $F$ & mãe & $2^{\circ}$ grau completo & Ana / 6 anos & Mãe e padrasto \\
\hline Bruna & 62 & $\mathrm{~F}$ & Avó & $1^{\circ}$ grau incompleto & $\begin{array}{lll}\text { Bento } / 8 & 8 \\
\text { anos } & \end{array}$ & Mãe, tia e avó \\
\hline Célia & 31 & $F$ & mãe & $1^{\circ}$ grau incompleto & $\begin{array}{lll}\text { Carla } & / & 11 \\
\text { anos } & & \\
& & \end{array}$ & $\begin{array}{l}\text { Mãe, irmão e } \\
\text { padrasto }\end{array}$ \\
\hline Diego & 64 & $M$ & Avô & $1^{\circ} \mathrm{grau}$ incompleto & $\begin{array}{lll}\text { Daniela / } 6 \\
\text { anos }\end{array}$ & Mãe, avó e avô \\
\hline Eliana & 25 & $F$ & mãe & $2^{\circ}$ grau completo & $\begin{array}{l}\text { Eduardo / } 8 \\
\text { anos }\end{array}$ & Mãe e pai \\
\hline Fernanda & 40 & $F$ & mãe & Superior incompleto & $\begin{array}{ll}\text { Fábio } / 5 \\
\text { anos }\end{array}$ & Mãe e pai \\
\hline Graça & 31 & $\mathrm{~F}$ & mãe & $2^{\circ}$ grau incompleto & $\begin{array}{l}\text { Gabriela / } 8 \\
\text { anos }\end{array}$ & $\begin{array}{l}\text { Mãe, pai e } \\
\text { irmão }\end{array}$ \\
\hline Horácio & 45 & $\mathrm{M}$ & Pai & $1^{\circ}$ grau incompleto & $\begin{array}{l}\text { Helena / } 13 \\
\text { anos }\end{array}$ & $\begin{array}{l}\text { Mãe, pai, } 2 \\
\text { irmãos e } 1 \text { irmã }\end{array}$ \\
\hline Inês & 27 & $F$ & mãe & $1^{\circ}$ grau incompleto & lara / 3 anos & $\begin{array}{l}\text { Mãe, pai e } \\
\text { irmão }\end{array}$ \\
\hline Julia & 39 & $\mathrm{~F}$ & mãe & $2^{\circ}$ grau completo & $\begin{array}{lll}\text { Jorge } / 6 \\
\text { anos }\end{array}$ & $\begin{array}{l}\text { Mãe, pai, } 1 \\
\text { irmão e } 1 \text { irmã }\end{array}$ \\
\hline José. & 51 & $M$ & Pai & $2^{\circ}$ grau completo & $\begin{array}{lll}\text { Jorge } / 6 & \\
\text { anos } & \end{array}$ & $\begin{array}{l}\text { Mãe, pai, } 1 \\
\text { irmão e } 1 \text { irmã }\end{array}$ \\
\hline
\end{tabular}

mães $(n=7)$. O grupo conta, ainda, com a participação de dois pais e dois avós.

\footnotetext{
${ }^{1}$ Nomes fictícios, a fim de preservar o anonimato, foram dados aos participantes desta pesquisa, seguindo a ordem alfabética. Os membros da família 1 têm nomes que começam com A, da família 2 com B, e assim por diante.
} 
Tabela 3.2 Características dos participantes do grupo indireto

\begin{tabular}{|c|c|c|c|c|c|c|}
\hline Participantes & $\begin{array}{l}\text { Idade em } \\
\text { anos }\end{array}$ & sexo & Parentesco & Escolaridade & $\begin{array}{l}\text { Pacientes / } \\
\text { idade }\end{array}$ & Grupo familiar \\
\hline Antonio & 22 & $M$ & Padrasto & $2^{\circ}$ grau incompleto & Ana / 6 anos & Mãe e padrasto \\
\hline Bianca & 27 & $F$ & Mãe & Superior completo & Bento / 8 anos & Mãe, tia e avó \\
\hline Celso & 42 & $\mathrm{M}$ & Padrasto & $1^{\circ}$ grau incompleto & Carla / 11 anos & $\begin{array}{l}\text { Mãe, irmão e } \\
\text { padrasto }\end{array}$ \\
\hline Dirce & 52 & $\mathrm{~F}$ & Avó & Superior completo & $\begin{array}{lll}\text { Daniela } / 6 & \\
\text { anos } & \end{array}$ & Mãe, avó e avô \\
\hline Denise & 23 & $F$ & Mãe & $1^{\circ}$ grau completo & $\begin{array}{lll}\text { Daniela } / 6 & \\
\text { anos } & \end{array}$ & Mãe, avó e avô \\
\hline Elcio & 39 & $\mathrm{M}$ & Pai & $2^{\circ}$ grau completo & $\begin{array}{ll}\text { Eduardo } / 8 \\
\text { anos }\end{array}$ & Mãe e pai \\
\hline Flávio & 49 & $\mathrm{M}$ & Pai & Superior incompleto & Fábio / 5 anos & Mãe e pai \\
\hline Gerson & 32 & $\mathrm{M}$ & Pai & $2^{\circ}$ grau completo & $\begin{array}{lll}\text { Gabriela / } 8 \\
\text { anos }\end{array}$ & $\begin{array}{l}\text { Mãe, pai e } \\
\text { irmão }\end{array}$ \\
\hline Helga & 43 & $F$ & Mãe & $1^{\circ}$ grau incompleto & $\begin{array}{l}\text { Helena / } 13 \\
\text { anos }\end{array}$ & $\begin{array}{l}\text { Mãe, pai, } 2 \\
\text { irmãos e } 1 \text { irmã }\end{array}$ \\
\hline Igor & 35 & $\mathrm{M}$ & Pai & $1^{\circ}$ grau incompleto & lara / 3 anos & $\begin{array}{l}\text { Mãe, pai e } \\
\text { irmão }\end{array}$ \\
\hline
\end{tabular}

Este grupo, como pode ser observado nesta tabela, é um grupo mais heterogêneo, formado por 4 pais, 2 padrastos, 3 mães e 1 avó.

\subsection{Tipo de pesquisa}

A pesquisa realizada é o que se chama de pesquisa ação, que tem como característica principal articular, ao mesmo tempo, o exercício da pesquisa à ação sobre a realidade. Pesquisador e pesquisado são agentes 
complementares, implicados em uma determinada situação de modo a identificar problemas e buscar soluções. A pesquisa ação tem o propósito de interpretar e explicar aspectos da realidade para então, poder intervir sobre ela (Lima, 2005).

\subsection{Recursos materiais}

* Filmadora Panasonic NV VZ 175 BR

* Fitas Sony VHS-C para as filmagens

* Tripé para a filmadora a fim de garantir a qualidade das filmagens.

* Vídeo Cassete e Televisão para observação das filmagens.

* Gravador de fitas K7 Fitas K7 para as gravações.

* Notebook Toshiba A45 1501 para a transcrição, tabulação e análise dos resultados.

* Cds para gravar as informações digitalizadas.

* Máquina fotográfica digital Sony Cybershot P73

\subsection{Elaboração do roteiro de entrevista}

* Fitas k-7 com 90 horas aproximadamente de gravações das reuniões do Grupo de Pais dos anos de 2000, 2001 e 2002

* Roteiro de entrevista para verificar o comportamento comunicativo de pais e familiares de crianças surdas, elaborado com os tópicos: dificuldade de comunicação, estratégias de comunicação, negação e aceitação da surdez, envolvimento e relacionamento familiar e ajuda profissional, categorizados a 
partir das gravações das reuniões do grupo de pais dos anos de 2000, 2001 e 2002

Para a elaboração do roteiro de entrevista, foram transcritas cerca de 90 horas, de gravações das sessões do Grupo de Pais dos anos de 2000, 2001 e 2002. Posteriormente realizou-se um levantamento dos temas recorrentes e sua categorização. Após a tabulação e análise destes, verificou-se que os temas que surgiram eram na sua maioria referentes à: dificuldade de comunicação, estratégias de comunicação, negação e aceitação da surdez, envolvimento e relacionamento familiar e ajuda profissional. Essa categorização foi realizada de acordo com a análise qualitativa proposta por Ritchie \& Spencer (1994), utilizada e adaptada por Carvallo, et al. (2004).

A partir da categorização dos temas, foi elaborado um roteiro de entrevista para verificar o comportamento comunicativo entre pais, familiares ouvintes e a criança surda.

Este roteiro foi aplicado nos dois grupos, Grupo Direto e Indireto.

$\underline{\text { Roteiro de entrevista sobre o comportamento comunicativo das famílias }}$ ouvintes com seus filhos surdos

1. Qual o seu nome e a data de nascimento?

2. Qual o nome do seu filho e a data de nascimento dele?

3. Que tipo de escola seu filho freqüenta? 
4. Quem primeiro percebeu que seu filho não escutava? E como foi essa descoberta?

5. Quando a surdez de seu filho foi efetivamente diagnosticada?

6. Quando seu filho recebeu o primeiro Aparelho de Amplificação Sonora Individual? Foi através de compra ou doação?

7. Quando foi a primeira vez em que seu filho iniciou tratamento fonoaudiológico?

8. Quais eram suas expectativas ao procurar atendimento no Laboratório de Investigação Fonoaudiológica em Audiologia Educacional?

9. Seu filho usa os AASI em casa? Quanto tempo por dia ele usa o AASI? Qual a relação que ele tem com o aparelho? E você?

10. A comunicação / interação entre vocês se altera quando ele está com os aparelhos?

11. como se estabelece a comunicação entre você e seu filho? Como se dá a interação entre vocês? Em que língua?

12. Existe alguma forma (estratégia) para que essa comunicação se efetive (estabeleça)?

13. Como as outras pessoas da casa se comunicam com seu filho?

14. Como foi a aceitação ou não da Língua de Sinais? Como é a Língua de Sinais para você?

15. Como você avalia as reuniões do grupo de pais?

16. Você conversa com as outras pessoas da casa sobre o que foi discutido no grupo? 
17. Mudou alguma coisa na sua família depois que iniciou tratamento no laboratório?

18. Hoje, quais são as suas expectativas?

19. Você daria alguma contribuição? Tem mais alguma coisa que gostaria de colocar?

As questões de números 1 a 8 fazem parte do que Szymanski (2002) denomina de período de aquecimento, a fim de criar um clima mais informal para a realização da entrevista. Este período auxilia o processo criando um clima de descontração e muitas vezes constitui uma introdução sobre o que vai ser tratado. Além disso, essas questões também caracterizam os sujeitos participantes da pesquisa.

\subsection{Procedimento}

Ao final do primeiro semestre de 2004 , durante uma das reuniões do Grupo de Pais, conversou-se com os participantes sobre esta pesquisa para a qual foram convidados a fazer parte. Foi solicitada e explicada a necessidade do comparecimento de todos, pois os resultados seriam importantes para a qualidade e continuidade das reuniões do Grupo geral.

Foi então feito um agendamento global de acordo com a disponibilidade da família, garantindo a presença dos dois ou mais membros. 
No horário marcado, a família comparecia ao CDP e um dos membros subia a sala onde seria feita a entrevista, enquanto que o outro membro aguardava na sala de espera.

Para que não houvesse contaminação nas respostas do roteiro de entrevista, logo após a primeira entrevista, o segundo entrevistado era chamado da sala de espera onde havia permanecido durante a aplicação da primeira entrevista. A chamada do segundo participante era sempre imediata para que não houvesse troca de informações.

A aplicação do roteiro se dava em uma sala silenciosa, previamente arrumada com duas cadeiras com mesas (uma para o entrevistado e outra para o entrevistador) de forma que ambas eram captadas pelas filmadoras acopladas a dois tripés para garantir a estabilidade das filmagens. Além disso, um gravador era estrategicamente posicionado sobre a mesa do entrevistado para garantir a qualidade da gravação.

Todas as entrevistas foram gravadas e filmadas após a assinatura do Termo de Consentimento Livre e Esclarecido aprovado pela Comissão de Ética para a Análise de Projetos de Pesquisa (CAPPesq) do Hospital das Clínicas da Faculdade de Medicina da Universidade de São Paulo, número 114/03 (Anexo 1). Cada entrevista durava em média 30 minutos. 
É importante ressaltar que para garantir um maior rigor científico, todas as entrevistas foram realizadas sempre pela mesma pesquisadora, que já era conhecida dos participantes. Este fato garantiu confiança e tranqüilidade na hora de expressarem determinados assuntos por parte dos participantes.

Foram realizadas entrevistas com 21 (vinte e um) pais e/ou responsáveis ouvintes das crianças surdas atendidas no LIFAE, sendo que destes, 11 (onze) são participantes diretos e 10 (dez) são participantes indiretos do Grupo de Pais.

Todas as entrevistas foram filmadas e gravadas e posteriormente transcritas completamente uma vez que, durante as entrevistas, vários participantes utilizaram sinais e gestos para elucidar como a interação e a comunicação ocorrem entre eles e seus filhos surdos.

\subsection{Análise dos dados}

Os dados dessa pesquisa foram analisados quantitativa e qualitativamente. Para Souza \& Gomes (2003) quantidades e qualidades compõem um campo de figura - fundo e são partes móveis de um mesmo todo, fazem parte da mesma cena, podendo assumir diferentes configurações que permitirão diferentes visões dependendo do ponto de vista. A análise quantitativa por si só deixaria de fornecer ricas informações que podem ser realçadas através de análise qualitativa. 
Segundo Ribeiro (2000), a pesquisa qualitativa oferece a oportunidade de novas interpretações, onde pesquisador e pesquisado gozam de paridade. Abre-se caminho para as emoções e interações sem romper com os dados quantitativos. A pesquisa qualitativa evidencia emoções, descortinando novos rumos, apontando para o mais próximo possível da realidade.

Os dados coletados nas entrevistas foram tratados qualitativamente, correspondendo a duas fases das três fases propostas por Meihy (1998). A transcrição e a textualização. Para a transcrição fez-se uma passagem fiel do que foi dito para a grafia, ou seja do oral para o escrito, mantendo o modo de expressão genuína com as hesitações, erros de concordância, mudanças de pensamento no decorrer da fala, risos, choros e pausas.

Após a fase de transcrição passou-se para a segunda fase, a textualização. Foi feita uma reorganização do discurso, suprimindo a fala do entrevistador, incorporando-a na fala do depoente e obedecendo a estrutura que um texto escrito requer para que a leitura seja agradável e compreensível.

\subsubsection{Análise quantitativa}

Para a análise das questões de número 9 em diante foram elaboradas duas tabelas diferentes: $A$ - análise intrafamiliar e B - análise entre as famílias. 
Foi então calculada a porcentagem de ocorrência das variáveis contidas nas duas tabelas.

\subsubsection{Análise qualitativa}

Para a análise qualitativa dos dados foram organizados Discursos dos Sujeitos Coletivos seguindo a técnica proposta por Lefevre \& Lefevre (2005) do Discurso do Sujeito Coletivo. Segundo os autores a elaboração do Discurso do Sujeito Coletivo é uma forma de reconstruir as representações existentes no campo pesquisado a partir do discurso de sujeitos, coletados principalmente a partir de entrevistas.

Com as entrevistas coletadas, o passo seguinte foi analisar questão a questão de todos os entrevistados, assinalando as "expressões chave" de cada depoimento. As expressões chave revelam a essência de cada fala. Feito isso, as idéias centrais foram identificadas a partir das expressões chave. Segundo os autores, é importante ressaltar que a idéia central é uma descrição do sentido de um depoimento e não uma interpretação do que foi dito. Os discursos podem ter o que os autores chamam de ancoragem, que é uma manifestação de uma dada teoria mas que nem sempre está presente nos depoimentos.

O passo seguinte foi agrupar as idéias centrais de sentido equivalente, iguais ou complementares, para então sequenciar essas idéias de forma clara, 
coerente e coesiva, utilizando conectivos e eliminando particularidades, como sexo, idade, etc. Os discursos são apresentados em itálicos pois são depoimentos coletivos.

O esquema abaixo ilustra as etapas que compõem esta pesquisa.

Figura 3.1. Fluxograma das etapas desta pesquisa

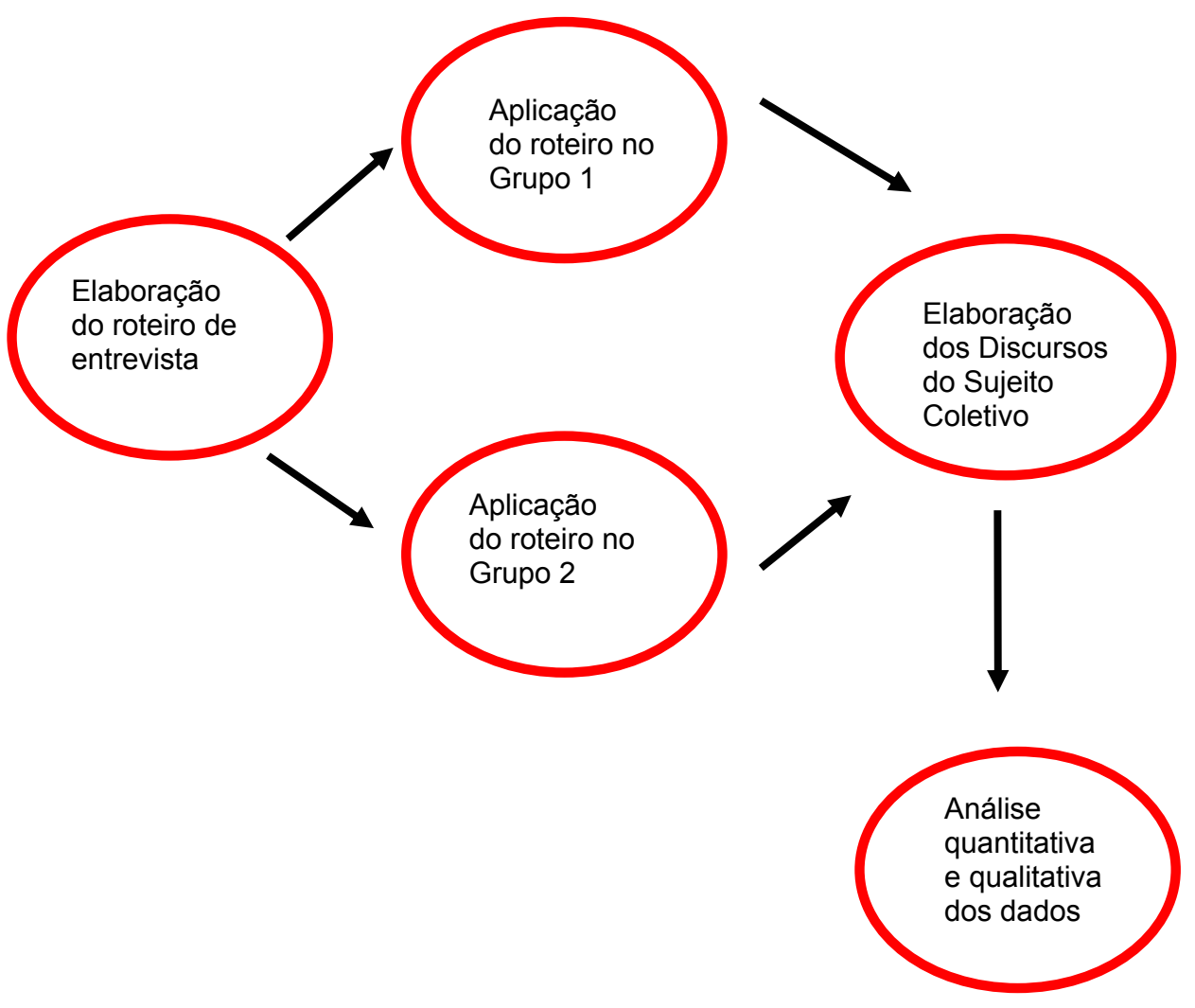


4. Apresentação dos dados 
A seguir serão apresentadas, por famílias, as textualizações das entrevistas realizadas. A primeira refere-se ao participante do Grupo Direto e as demais, aos participantes do Grupo Indireto da mesma família. Na família 10, as duas textualizações são de participantes do Grupo Direto, pois ambos comparecem sistematicamente às reuniões do Grupo de Pais.

Conforme a explicação da tabela 3.1, foram dados nomes aos membros de cada família, seguindo a ordem alfabética: Família 1, nomes com A, família 2, nomes com B e assim por diante. Nos casos em que há Dona ou Sr. (Seu) na frente dos nomes, referem-se aos avós das crianças atendidas no LIFAE.

\section{Família 1 (F1)}

A) Amanda - mãe da Ana

Meu nome é Amanda e nasci em vinte e sei do seis de oitenta e dois. Minha filha se chama Ana e ela nasceu em doze do nove de noventa e oito. A Ana estuda em uma escola própria para pessoas com surdez, da Fundação Rotariana.

A primeira pessoa que percebeu que a Ana não escutava foi a Dona Alice, a avó dela, mãe do pai dela. Primeiro ela ficou preocupada porque a Ana não andava, ela achou que ela tinha problemas nas pernas. Depois quando a gente a chamava para andar, ela não olhava, mas a gente não achava que era alguma coisa no ouvido. Aí, ela trouxe a Ana aqui na USP, na neurologia e 
falaram que era surdez. Quando ela contou para gente que era surdez, eu Ave Maria, chorei de mais. Eu não queria que a minha filha fosse surda. Eu chorei muito!

A Ana tinha um ano e seis meses, porque foi em abril que viemos aqui fazer o BERA. E a surdez foi diagnosticada quando ela tinha um ano e sete meses. A neurologia encaminhou para cá para termos certeza. Quando viemos para cá em abril, ela estava com inflamação de ouvido, e nos falaram que poderia ser surdez ou não, em razão da inflamação, mas que um pouco ela tinha, só não dava para descobrir qual o grau.

Nós voltamos em maio, no finalzinho de maio para fazer outro BERA. Ela já não estava mais com inflamação porque eu já tinha cuidado, e então foi detectado que ela era surda mesmo.

Quando a Ana tinha dois anos ela recebeu o seu primeiro aparelho. A gente comprou um aparelho daqueles que empurram para gente comprar, sem fazer teste. E como estávamos desesperados com a surdez da Ana, fomos na São Camilo e colocamos qualquer aparelho nela. A gente nem sabia se o aparelho era bom ou não. Tanto que ela não teve resultado nenhum, ela até arrancou e jogou na Raposo (Rodovia Raposo Tavares). As duas famílias ajudaram para comprar, dividimos entre todo mundo da família, a família dele e a minha família. 
Logo que ela recebeu o aparelho, a gente foi para Derdic, mas lá ela ficou por pouco tempo, e depois vocês já chamaram. Ela tinha dois anos e pouco. Não sei exatamente.

Em casa, a Ana usa o aparelho bem pouco. Teve uma época em que eu ainda estava forçando, e ela estava usando sempre, mas ela dizia que incomodava, que ela não queria, então em casa ela só usa quando quer, mas ela não pede nunca, pelo contrário, ela faz assim (com a mão, diz que não quer) que ela não quer, porque ela não gosta, acho que por causa do barulho. Às vezes quando põe o aparelho, ela fica escutando, aí ela faz assim (sinal de dor) que está incomodando. Agora, na casa do pai dela, usa desde a hora em que ela chega, até a hora em que ela vai embora. A avó dela põe o aparelho e na hora em que ela vai embora para minha casa ela tira. A avó não tira, mas ela tira sozinha. Na casa do pai dela e quando eles vão viajar, todos os dias ela fica com o aparelho. Então acho que ela é folgada comigo. (risos)

Por mim ela só tirava o aparelho para dormir e tomar banho. Mas tem outra coisa, eu estou muito cansada, não sei o que está acontecendo comigo, mas antigamente eu estava estimulando mais, agora estou um pouco cansada, mas eu gosto que ela use, por mim ela usava direto, na escola ela usa direto.

Eu me comunico com a Ana da mesma forma, esteja ela com ou sem aparelho, às vezes eu até esqueço de falar. 
Quando eu vim procurar atendimento aqui na USP eu não tinha expectativa, acho que, nenhuma. Porque eu era totalmente contra a surdez, eu queria que ela falasse. Não queria nem que ela falasse em sinais, podia amarrar a mão dela, não deixar ela falar em sinais, a minha cabeça era essa. Eu não gostava não. Achava estranho eu passar na rua e os outros falando que a minha filha falava em sinais, eu não gostava, detestava.

Eu a trouxe aqui para aprender a falar, com a boca só. Tanto que eu quase forçava no começo :- fale, fale. Ficava tão nervosa: - eu quero que você fale! Depois com o tempo eu fui mudando.

Hoje a nossa comunicação é perfeita. Só em sinais, mas é perfeita. O que eu não sei em sinais, eu procuro um jeito para fazer ela entender, é lógico que eu não sei tudo, porque tem só dois anos que eu estou firme e forte nos sinais, mas eu entendo tudo o que ela quer. Quando eu não entendo, eu faço umas mímicas, (risos) pego um negócio, faço de um jeito, e mímica. Quando eu não consigo falar com ela, que ela não está entendendo, eu faço umas mímicas para ela conseguir me entender ou eu pergunto para os professores surdos. Então a minha comunicação com ela é muito boa. Aliás eu sou a única pessoa, porque o resto, só fala o necessário tanto o pai, quanto o meu marido, quanto minha mãe, todo mundo. Agora parece que depois que eu comecei a tomar conta da Ana eles se desleixaram um pouco, deixaram um pouco para lá essa história de aprender a se comunicar com a Ana. Eles perguntam muito: como é que fala tal coisa? Eles sabem algumas coisas, não tudo, nem passa 
perto do que eu sei. O meu marido pergunta, ele fala com ela às vezes: - ai caramba, né, ela não escuta! Mas ele tenta. Os outros às vezes falam para eu falar: - fale, fale para ela tal coisa, fale que não pode. É assim que eles se comunicam. Ninguém se interessa muito em saber sinais, essa é a realidade. 0 Antonio só está aprendendo porque tem uma enteada surda, porque também não ia se interessar, mas mesmo assim não é um interesse totalmente interesse, é que ele tem que se comunicar com ela, então ele tem que aprender isso. Não é uma coisa que ele goste como eu gosto, até porque minha filha é surda.

No início eu tinha que arrumar um jeito de falar com a Ana, a minha motivação para aceitar a Língua de Sinais foi essa, eu via o J e a J (pais de outra criança surda) e ficava admirada. O D (criança surda) falava tudo, ele conseguia falar para mãe dele que ele queria prestar atenção no que a mãe dele estava falando. E eu pensava que se eu não me interessasse em falar com a minha filha, porque falar ela não vai falar pois ela já ia fazer quatro anos e não sabia falar nada. Às vezes eu queria falar para ela que a amava e não sabia como. Às vezes eu queria dar um chamego nela, uma bronca, e ela só estava achando que eu era um monstro. Então no começo foi porque era preciso. Agora não, depois com o tempo eu fui gostando, fui conversando com outras pessoas surdas. Agora eu adoro, gosto pra caramba.

Quanto às reuniões do grupo de pais, acho que se não fossem elas eu estaria um monstro até hoje com a minha filha. Acho que seria legal se a 
família inteira participasse, mas o problema é o tempo que ninguém tem, mas se todas as pessoas da minha família viessem aqui na reunião e vissem como que é a vida do surdo, se vissem como é a comunidade, como uma pessoa surda é, acho que não iria ter tanto preconceito da família, pois todo mundo iria aceitar, iria aprender a Língua de Sinais e iria começar a gostar dessa comunidade, da Língua de Sinais, de tudo. Eu acho importante, se não fossem as reuniões, eu não iria ser quem eu sou.

Às vezes eu quero falar com os outros em casa e eles me cortam, então não, não converso com eles sobre o que acontece aqui. Só às vezes com a minha mãe que é quem mais pergunta e a minha sogra, mas isso era no começo, agora ninguém mais pergunta. Só às vezes quando a gente coloca um assunto do tipo do implante coclear, que chama atenção deles, aí eles ficam entretidos, mas fora isso, eles até cortam o assunto.

Desde que iniciamos tratamento aqui, a Ana parou de ser nervosa. Ela era muito nervosa, ela até batia em mim, agora não. Agora ela melhorou bastante, não é mais agressiva. Às vezes ela vem (fez mímica de querer bater), eu olho feio para ela e ela já entende. A agressividade mudou bastante, a comunicação, a meiguice da Ana comigo. Isso mudou bastante. $O$ comportamento dela, agora ela é uma criança educada. Hoje se ela entra em um lugar e eu falo que não tenho dinheiro, ela aceita bem, a educação da Ana mudou bastante. Desde que eu comecei a vir, não no começo que era a minha 
mãe, a Ana mudou radicalmente, deu uma guinada de trezentos e sessenta graus, mudou bastante.

Hoje eu só quero que a Ana fale, não por mim, porque por mim está ótimo, mas pela sociedade. A sociedade é preconceituosa, e se a Ana não falar, pelo menos não conseguir perguntar onde é tal coisa, entender o que os outros falam, como a professora surda de Língua de Sinais que é uma pessoa que fala, que lê lábios e consegue se comunicar com qualquer um, tanto surdo como ouvinte. E é o que eu queria que a Ana fosse, uma pessoa como a professora surda, para ela conseguir viver, arrumar emprego, trabalhar e ser uma pessoa normal, só com um probleminha, é isso que eu queria.

B) Antonio - padrasto da Ana

Meu nome é Antonio e nasci em vinte nove do doze de mil novecentos e oitenta e dois. O nome da minha enteada é Ana. e a data de nascimento eu não me recordo, mas ela tem seis anos. A Ana estuda na escola especial pra surdos do Rio Branco.

Eu creio que a primeira pessoa que percebeu que a Ana não escutava foi a avó dela, mas eu não sei como foi essa descoberta e nem quando a surdez dela foi diagnosticada porque quando eu conheci a Amanda, a Ana já tinha cinco anos. Quanto ao primeiro aparelho, eu também não sei quando ela recebeu, mas ela começou tratamento fonoaudiológico há cinco anos. 
A Ana usa aparelho só para ir para escola, em casa às vezes ela usa. Ela não consegue ficar com ele, ela tira. Você coloca e ela tira, você coloca e ela tira, e aí corre o risco dela perder, como o aparelho é muito caro, ela pode perder ou quebrar como ela já fez com os outros aparelhos, então ela usa mais na escola.

A gente tenta gesticular mais com a boca para ver se ela percebe que você fala com a boca, porque tem vezes que ela fica até te imitando. Você está falando e ela fica lá mexendo a boca igual a você, às vezes ela fala que não está entendendo, mas já querendo falar com a boca e é sempre do mesmo jeito mesmo ela estando com ou sem o aparelho.

Eu gosto quando ela usa o aparelho porque tem os médicos que dizem que, através do aparelho ela pode voltar até a escutar alguma coisa. Então sem o aparelho não tem como ela fazer o tratamento.

Eu não sei fazer sinais, mas quando é alguma coisa que eu quero falar para ela eu pergunto para Amanda e a Amanda me mostra em gestos como é que se faz e eu falo para ela, e o que ela fala para mim, eu pergunto para Amanda Eu já estou entendo algumas coisas, já estou aprendendo a falar algumas coisas, através de um livro que nós temos lá em casa e no convívio também você vai aprendendo, é assim que nos comunicamos. Quando a Ana está falando comigo, a Amanda sempre fica atenta, ela fala comigo e eu olho para Amanda, então ela já gesticula, fala o que a Ana está querendo falar. 
Mesmo convivendo com ela há pouco tempo, a minha expectativa é que estimule, tanto ela como a mãe também, e que ela continue vindo e progredindo igual elas estão. A Amanda tem mais o jeito especial como mãe, ela entende mais, conversa mais com a filha dela, então já é diferente. Algumas coisas ela fala e eu não entendo, mas a Amanda entende tudo, então ela tem um jeito mais carinhoso de falar com a Ana.

Quanto à Língua de Sinais, eu aceito, aceito porque é o único jeito que ela tem de se expressar. Por enquanto ela não aprendeu a escrever, porque a partir do memento que ela aprender a escrever, vai ser um jeito a mais. Se ela fizer o gesto e a pessoa não entender, ela pode escrever então a gente também a estimula bastante a fazer as letras.

A Amanda que vem nas reuniões do grupo de pais, mas eu acho muito bom porque um pai fala com outro reunido aqui. Um sabe o problema do outro, vai contando um o problema do outro e aqui eles tentam solucionar, perguntam porque que a criança está assim, porque sempre tem algum motivo, a criança vai reagir sempre por algum motivo, então aqui vocês discutindo é muito bom, para o psicológico porque um pai se abre pro outro, não fica aquele negócio porque um filho é surdo, porque o filho não consegue fazer isso, não consegue fazer aquilo. Então aqui eles vêem que não é só o seu filho que tem esse problema, outras crianças também tem e muitos pais convivem com isso muito bem, se sobressaem sobre isso sem nenhum problema e eu acho isso bom. 
Eu saio cedo de casa e a Amanda também já passa aqui e vai direto para o serviço então a gente só se vê a noite, mas ela é uma menina muito inteligente, a Ana a cada dia aprende uma coisa nova. Ela chega em casa alegre contando o que aconteceu, então você acaba sabendo que ela caiu na escola, que ela brigou, que ela brincou disso e aprendeu aquilo, ela é uma criança bem comunicativa.

Hoje eu espero que, do que depender de mim, é dar todo apoio, toda força, todo apoio que ela precisa para ela continuar desenvolvendo. Eu já vi, conheci criança surda que com muita vontade que tem de falar, acaba falando as palavras e a minha intenção é ajudar. Como eu gosto, aprendi a gostar muito dela e ela gosta muito de mim também, tanto é que ela é muito carinhosa, então a minha expectativa é crescer com ela. Ela crescendo no tamanho e na inteligência e eu também crescendo, aprendendo com ela.

\section{Família 2 (F2)}

A) Dona Bruna - avó do Bento

Meu nome é Bruna e eu nasci em catorze de fevereiro de como é, dois mil, eu vou fazer sessenta e quatro, dois mil e, a cabeça que não dá, é de quarenta e dois.

O nome do meu neto é Bento e ele nasceu no dia vinte e dois de fevereiro. É o ano... dois, ai não, minha cabeça... E ele freqüenta a escola mesmo para eles, para os surdos, eu esqueço como é que é.... Especial sim, 
desculpa, ele já estudou um ano na escola particular, normal, mas porque não tinha ainda o lugar para ele, a vaga. Depois entrou com três anos nessa escola, já tem seis anos que ele estuda lá.

Fui eu quem primeiro percebeu que o Bento não escutava. Ele ficava deitadinho e às vezes ele dava aquele choro e sacudia a cabecinha. Ficava com a cabecinha sacudindo. A gente colocava aquele brinquedinho de música e ele não ligava. Em vez de chorar ele fechava os olhinhos e eu falava pra minha filha que esse menino tinha um problema, que a gente devia ir para o médico.

A gente o levou em uma médica, uma japonesa e ela disse que ele não tinha nada, que a mãe é muito, como é que se diz, preocupada demais, mas que ele não tinha nada, que ele era um menino são. Eu disse para ela que me desculpasse, que eu tenho dez filho, eu os criei e acho que estou entendendo mais (risadas), aí ela disse para mudarmos para outro médico. Aí mudamos para outro médico, de sessenta anos. Ele mandou a Bianca se sentar e fez todas as perguntas sobre a gravidez dela, de como foi o começo da gravidez dela e ela falou. E fomos fazer os exames. Depois ele disse para fazermos os exames e deu certo. Nessa época ele tinha seis meses e um mês e pouco depois ele deu a informação toda, a gente fez os exames todos e ele falou que sim. 
O primeiro aparelho, ele ganhou quando estava com três anos e meio. E foi a gente que comprou. A gente tentou e comprou. A Bianca fez uma rifa, ela comprou um som, fez uma rifa e arrumou um pouco de dinheiro, a outra parte ela colocou do dela. Quando passou o ano que ela recebeu o décimo terceiro, ela já completou no aparelho.

Ele começou tratamento fonoaudiológico na Santa Casa. Parece que foi na Paulista, no Hospital São Paulo primeiro. Depois acho que mudou para Santa Casa e ele tinha uns dois anos.

O Bento não quer usar aparelho em casa. A gente reclama com ele e ele diz que não gosta. Às vezes a gente coloca, ele vai para escola, outras vezes não. Não quer. Eu gosto do aparelho, mando ele colocar, digo que é bom, mas ele não aceita, não quer aceitar.

Logo no começo quando ele fez o teste dos três aparelhos, esse que ele usa hoje eu achei bom, porque, não sei se foi só naquela hora, mas eu estava na cozinha e eu chamei o Bento, ele fez que sim e apontou o dedo. Nunca aconteceu isso. Agora de lá pra cá, não... não sei o que foi naquele dia.

A gente quis vir aqui para USP porque todo mundo falava que tinha que ser, que era bom. E a gente tinha que vir encaminhada pra cá. E foi um lugar bom que a gente encontrou. Eu achava que ele iria falar e escutar, mas é o contrário. Eu achava isso, mas nada para Deus é impossível. Quem sabe... 
Dentro de casa eu chamo e às vezes ele olha para os meus lábios e outras vezes eu chamo, falo e ele entende. Às vezes ele faz pergunta das coisas e quando eu sei responder, eu respondo, ele fala que sim, que está bom. Muitas coisas ele pergunta para mim. O meu jeito é antigo. A mãe e a tia já são de outro. É do contrário. A mãe e a tia são um jeito, eu sou outro. Eu quero fazer como eu fiz com elas, mas é diferente porque às vezes eu quero botar ele numa coisa certa para dormir cedo, para acordar no horário certo e elas não botam. O caso é esse. Elas são mais, com o é que se diz, relaxadas, não ligam. Para elas está tudo bom, mas a avó é mais apressada, eu sou mais apressada das coisas.

Quanto a conversar com ele, as meninas falam do jeito de mim mesma. As meninas se comunicam com ele do mesmo jeito, falam, perguntam, respondem, elas respondem bem. Elas não vêm tanto aqui para aprender os sinais, elas até que respondem bem, porque a Bianca tem um livro, ela estuda sempre no livro, ela entende bem.

Eu aceitei bem a Língua de Sinais. Se eu pudesse, porque a pessoa quando está mais de idade a cabeça não é muito boa e eu nunca estudei. Para eu aprender é difícil. Umas coisas eu aprendo fácil, outras são difíceis para $\operatorname{mim}$.

Quanto às reuniões do grupo de pais, eu avalio que a gente, como é que é, que a gente se desenvolve mais. A gente aprende mais as coisas. 
Procura se entender mais com as pessoas porque ali no meio da reunião tem muita gente e a gente se entende bem com as outras. Eu gostei de todo mundo, de vocês também, que explicam as coisas para gente, eu acho que está bom.

Em casa eu converso, converso, converso, foi passado isso assim. Às vezes nem dá tempo porque quando a Bianca chega, eu estou deitada, e quando ela levanta de manhã, eu é que acordo às seis horas para ela levantar porque ela sai seis e meia, sete horas. Às vezes nem dá tempo de conversar.... Nos finais de semana eu saio e elas às vezes descansam até às dez horas. Muitas coisas não dão tempo, por causa disso.

Desde que começamos o tratamento algumas coisas mudaram. A Bianca chorava pra caramba. No começo, mudou, claro que mudou sim. Mudou que ela se conformou. Ela foi a lugares onde viu coisas piores que o filho dela. (Choro)

Hoje eu nem sei te dizer quais são as minhas expectativas. Eu espero que ele seja um bom menino. Ele fala que vai estudar, vai trabalhar com computador, fazer curso de computador e vai trabalhar para ter muito dinheiro. Ele fala isso, que vai casar com uma menina. Uma menina, para ele casar quando estiver homem e tiver muito dinheiro. E ainda fala que quer ter dois filhos. Eu acho interessante e quando perguntei o porque, ele disse que todo homem tem filho. Acho interessante isso que ele fala. 
Essa noite eu achei engraçado porque ele pegou um perfume e quebrou. Eu perguntei para que ele pegou esse perfume. E ele pediu desculpas, disse que vai pedir dinheiro para a mamãe e vai comprar outro e vai me dar, e que era para eu não chorar.

Para mim ele está bem. Às vezes é teimosinho, mas isso é do problema dele. Porque quase todos eles são nervosos...

B) Bianca - mãe do Bento

Meu nome é Bianca., tenho vinte sete anos e nasci no dia vinte oito do quatro de setenta e sete. Meu filho se chama Bento, nasceu no dia vinte e dois de fevereiro de noventa e seis e estuda em uma escola especial para deficiente auditivo.

Fui eu quem primeiro percebeu que o Bento não escutava. Havia barulhos na minha casa com os quais ele não se incomodava quando estava dormindo. A reação dele não era igual a dos meus outros sobrinhos, pois eu tinha sobrinhos também. Não era a mesma reação e eu comecei a achar estranho e falar que tinha alguma coisa errada com o Bento e todo mundo falava que não. Quando comecei a desconfiar, ele tinha dez a onze meses. E a surdez foi efetivamente diagnosticada com um ano e dois, três meses, mais ou menos. Levou alguns meses. Quando eu fui atrás de alguns médicos para saber, eles pediram alguns exames e foi quando fiz o BERA e detectou que ele realmente não ouvia. 
Quando o Bento tinha uns três anos, eu comprei seus primeiros aparelhos, e ele foi algumas vezes na Santa Casa, mas acho que o início da terapia fonoaudiológica foi definitivamente aqui.

O Bento não quer usar o aparelho, nem em casa e nem em nenhum lugar, nem na escola e nem pra vir pra cá. Ele se incomoda com o aparelho, ele falou que não gosta de usar. Por mim ele tem que usar. Já falei, deixei isso claro em casa, porque como eu trabalho o dia inteiro, eu falo que eu não estou aqui para colocar na hora, mas que desde a hora que ele acorda até a hora que ele for dormir, ele tem que ficar com o aparelho. Mas ele não usa, mas por mim ele usaria normalmente, não tem porque não usar.

Eu percebo que as reações dele são diferentes quando ele está com o aparelho, acho que ele fica mais rápido, qualquer barulho de movimentação, mas a comunicação não muda muita coisa. Eu falo do mesmo jeito com ele, por sinais ou olhando para ele e falando, que ele já entende um pouco.

Quando viemos aqui para USP, a minha expectativa era de que ele se desenvolvesse bem, como ele é hoje. Está certo! Eu pensei que ele fosse ler mais os lábios, que ele fosse emitir algum outro som, porque às vezes ele fala, não, vovó, ele fala essas palavras certas, ele consegue, outras não, não sei se é por preguiça, porque ele acha que não precisa, mas eu pensei que ele fosse falar algumas outras coisas. Ele já desenvolveu bem. O Bento não está precisando assim, lógico que ele pode evoluir mais, mas eu não sinto falta de 
alguma coisa que ele tenha que, na fala, por exemplo. A gente se comunica bem, seja falando, ele me entende, ou seja por sinais que ele já ensina para gente. Por exemplo, até hoje eu não consegui fazer um curso de Língua de Sinais, o que eu sei é o que ele me ensina. Por isso a nossa comunicação às vezes é um pouco complicada porque eu não sei tudo de Língua de Sinais, mas aí eu falo para ele que eu não sei. Às vezes ele fica irritado quando ele percebe que eu não sei. Aí eu peço para ele explicar para mim o que ele quer, daí ele vai e faz eu entender.

A comunicação se dá pelo dia a dia. A gente não freqüentava aula de sinais então foi natural, a forma da gente se comunicar. Eu falo mais com ele, eu não falo tanto por sinais, eu falo quando eu estou brava, ele sabe que estou brava, eu falo que não, ele já entende. Assim, por sinais também, o que eu não sei de sinais, eu falo para ele. Eu falo que eu tenho que aprender e aí ele fala. Mas a gente não estabeleceu, não existe uma regra. Eu acho que o que for mais fácil para ele e para mim e a gente se entender, então é isso, ele já percebe isso.

As outras pessoas da casa se comunicam da mesma forma, ou por sinais ou olhando para ele, falando e ele entendendo, ele lendo os lábios. É da mesma forma comigo, com a minha mãe e com a minha irmã que são quem moram com ele. 
Em relação à Língua de Sinais, eu aceitei bem, eu só não conheço muito bem. Eu sei que vou ter que fazer um curso, ou conviver mais com eles, não só com o Bento, mas os colegas dele e outras pessoas deficientes auditivas, mas a aceitação foi bem. Não teve problema de maneira alguma. É um pouco complicado, porque eu vejo ele falando com os coleguinhas, totalmente diferente da forma como a gente fala, mas a aceitação foi bem.

As reuniões do grupo de pais são muito boas porque são experiências que a gente realmente passou, quase todas parecidas. Às vezes a gente não acredita no começo, depois é aquilo, a gente aceita e vai se integrando no dia a dia da criança. E eu peço que a minha mãe me fale tudo o que aconteceu, até mesmo porque eu não posso estar aqui presente sempre. E eu peço, a mesma coisa para a minha irmã, quando eu não posso ir para as reuniões de pais na escola do Bento, quando ela chega, ela me fala.

Em casa o que mudou desde o início do tratamento foi a dinâmica, o relacionamento entre a gente. A gente procura conversar sobre isso, porque todo mundo trabalha, e tem o Bento que precisa de atenção. É a minha mãe que leva ou a minha irmã, então a gente procura conversar sobre isso. É um pouco complicado. Eu gostaria de fazer tudo pelo Bento, trazer, levar na outra escola, mas eu não posso, eu tenho a minha vida também, o meu trabalho, as coisas, mas gente procura conversar, a gente procura falar a respeito disso. 
O que eu espero, do Bento? Do tratamento, hoje? Que o Bento leia mais os lábios. Ele é muito agitado, às vezes desatencioso e então que leia os lábios, que solte mais sons porque ele se limita a falar e quando ele fala, ele fala bem, então é isso que eu não entendo. Ele fala vó muito bem, ele fala água, ele fala não perfeitamente e é isso eu fico esperando das outras palavras. O Bento é muito inteligente, não falta nada, assim.

\section{Família $3($ F3)}

\section{A) Célia - mãe da Carla}

Meu nome é Célia e a minha data de nascimento é vinte e cinco do dois de setenta e três. Minha filha se chama Carla e ela nasceu no dia vinte e oito do um de noventa e três, e freqüenta uma escola especial.

A primeira pessoa que percebeu que a Carla não escutava foi a minha irmã e ela ia completar uns dois anos, acho que ela tinha um ano e oito meses, quando a gente descobriu.

Aparentemente eu não estava querendo acreditar que ela era surda, mas a minha irmã, que ficava mais tempo com a Carla, pois nessa época eu era mãe solteira e trabalhava, começou a perceber. A Carla tinha muitas infecções de ouvido e a minha irmã disse que achava que a Carla não escutava. Eu falei com a médica e ela passou um exame, o BERA, para eu fazer. 
Então o exame foi feito e falaram para mim que ela não ouvia, ela tinha dois anos nessa época.

A Carla recebeu o primeiro aparelho quando tinha nove anos. Depois do exame eu fui à Prefeitura e para vários locais. Cheguei a ir até Bauru e depois me deram o endereço de Santo André. Me inscrevi pelo telefone, dando o meu nome e o nome da Carla. Passou um ano e eu consegui, por doação, o aparelho dela.

E ela ficou desde os dois anos quando foi dado diagnóstico até os nove anos sem usar aparelho.

Em casa ela usa pouco o aparelho e mesmo sabendo cuidar dele sozinha, ela não gosta dele pois sente dor de cabeça, desconforto. Por isso ela só usa quando vem aqui para a fono, e aí ela consegue ficar de manhã até o horário que ela chega da escola por volta das sete e meia. Quando ela não vem para a fono, às vezes fica sem o aparelho, e eu mesma acabo esquecendo de fazer com que ela coloque o aparelho, aí ela acaba ficando sem. E a gente não sente diferença alguma quando ela está com ou sem o aparelho.

A Carla começou tratamento fonoaudiológico quando ela tinha uns sete anos e durante um ano ficou no posto do Peri Peri, e quando terminou e não tinha mais fono e nem nada, ela foi chamada aqui. 
Eu achava que o tratamento ia ser bom, mas não achava que iria demorar tanto. Mesmo assim, a Carla progrediu bastante. Na verdade é uma coisa devagar e não vai ser totalmente como eu imaginava que seria. Eu imaginava que a Carla iria falar normal assim como a gente. Acho que é como todas as mães imaginam, que a Carla iria falar como a gente, que ela iria entender tudo. Lógico que ela entende, mas eu achava que seria uma coisa assim mais esperançosa. Mas está ótimo assim. Ela está progredindo bastante e agora eu estou entendendo como vai ser, ela vai falar, ela vai entender, vai saber tudo, mas a fala dela não vai ser tão legível como da gente. Agora eu estou entendendo melhor como vai ser.

Em casa geralmente a gente conversa como a gente está conversando, ou então quando ela não entende, ela pede para fazer algum sinal. Eu faço sinais ao mesmo tempo em que falo e às vezes eu falo com ela normalmente. Acho que é difícil assim, a gente acaba esquecendo que ela é surda e acaba falando como se tivesse falando com meu filho, meu marido.

Quando a gente não entende, ela fala devagar, ou ela tenta explicar melhor o que ela quer falar e aí a gente acaba se entendendo.

Quanto à Língua de Sinais eu aceitei numa boa. Fiquei feliz quando ela conseguiu essa escola porque eu achava que se não tinha como ela escutar, me entender, então tinha que ser dessa forma mesmo, porque não é difícil para eles entenderem. Então, assim que eu consegui essa escola, não via a hora 
dela ser chamada. A escola dela, a fono, tudo. Eu não via a hora, porque eu sabia que ali iria ser uma maneira dela poder me entender e entender melhor as pessoas. E é o que está acontecendo, ela está entendendo bastante!

As reuniões do grupo de pais, eu acho que é legal, porque a gente tira bastante dúvidas entre os pais. A gente passa quase as mesmas dificuldades, então quando a gente tem alguma dúvida, a gente sempre tira aqui na reunião dos pais e eu acho legal.

Desde que começamos aqui, as coisas em casa mudaram porque agora a gente se entende melhor, isso porque a gente conversa bastante aqui, e às vezes tem alguma coisa está errada em casa e a gente conversa. A gente acaba entendendo, acaba resolvendo o problema. E em casa, com o Celso, às vezes a gente conversa quando tem tempo, porque às vezes é muito corrido. Eu chego em casa e tenho que arrumar a Carla para ir para escola, e a noite ele vai trabalhar, mas sempre que tem uma oportunidade ele fala, eu também falo para ele como é que foi. Quando tem alguma coisa interessante, eu já chego falando para ele, mas a gente se comunica.

O Celso fala assim normal com a Carla. Acho que é até por isso que a Carla fala até bastante porque o Celso fala bastante com ela. Agora ele sabe um pouquinho de sinais porque ele passou um tempo vindo nas aulas, mas ele fala, conversa normal com ela e ela o entende. E quanto ao Carlos, o meu filho, 
ele usa bastante sinais com ela e conversa normal. Ele fala assim (mexe a boca sem emitir som) conversando com ela sem soltar a voz e fazendo sinais.

Hoje eu espero, agora que eu já sei como vai ser a vida dela, estou fazendo de tudo, para ela crescer, depender dela, ter um trabalho legal, estudar, ter a vida dela sem depender de mim mais tarde, como qualquer um de nós, eu espero isso dela.

B) Celso - padrasto da Carla

Meu nome é Celso e nasci no dia vinte e quatro do quatro de sessenta e dois. Minha filha se chama Carla e ela nasceu em vinte e oito, ai a data eu não sei.

A Carla estuda em uma escola para surdos. Acho que é especial. É uma escola que só surdos estudam.

Quando eu conheci a Carla ela já tinha três anos, mas a Célia falou que a Carla teve começo de meningite e se eu falar como e quando a surdez foi diagnosticada eu vou estar mentindo.

Na época em que a Carla recebeu o primeiro aparelho eu já estava com a Célia, faz uns três anos. A Célia foi morar comigo na minha mãe e ela começou a correr atrás para ver o aparelho, mas eu não me lembro a data, não sei se a Célia lembra também. A Carla tinha uns sete anos. 
De vez em quando, a Carla usa o aparelho em casa. Ela não usa muito, porque a gente tem medo de que quebre, pois ela brinca muito com o Carlos. Ela usa mais quando vai para escola. Ela sai às onze horas e fica até às cinco horas, e quando chega em casa a noite, ela tira. Ela gosta do aparelho, não reclama dele não, ela só não gosta muito de usar em casa. E a gente conversa da mesma forma quando ela está com e sem o aparelho.

A Carla começou tratamento fonoaudiológico aqui na USP. Ela foi morar comigo e começamos a correr atrás até ela entrar aqui. Acho que demorou uns dois anos até ser chamada. Nós ficamos muito contentes porque era outra coisa para ela, porque ela só ficava em casa. Quando ela conseguiu aqui, nós dois ficamos muito contentes, minha mãe também ficou muito contente, porque assim ela vai desenvolvendo, na escola, aqui, ela vai se desenvolvendo.

Eu falei para Célia que ela ter conseguido terapia de fono aqui foi a melhor coisa. Agora ela desenvolveu muito mais, está bem melhor do que se ela não tivesse conseguido aqui e se não estivesse estudando. Acho que ela iria ficar lá em casa parada, tipo uma criança (fez cara de uma pessoa olhando para o nada), então nós gostamos muito.

A gente se comunica por gestos, por exemplo, ela está vendo televisão, e quando ela não entende ela pergunta o que é, e então eu e a Célia falamos. E quando ela quer alguma coisa, ela se comunica. Eu não sei muitos 
sinais, mas o que eu sei já dá para nos entendermos muito. Ela usa mais sinais, ela pega, ela mostra quando quer alguma coisa, ela fala com a mão (faz sinais) e dá para entender. Eu estava vindo aqui nas segundas feiras para ter aula de sinais, e então quando eu a levo pra escola, a gente vai dentro do ônibus conversando, ela mostra alguma coisa dentro do ônibus, na rua, e a gente vai se entendendo melhor. $\mathrm{E}$ isso com o tempo melhora.

Quanto à Língua de Sinais, se eu pudesse vinha toda segunda feira, pois aprendi um monte de coisas, é outro mundo, outra coisa, eu gosto! Acho que ela é importante, principalmente para se comunicar, quando eu a levo para escola, eu vejo um monte de crianças falando e o pessoal dentro do ônibus fica só olhando, porque vê o aparelho. E eles perguntam para mim o que eles estão falando. Nossa, é muito bom isso!

Em relação às reuniões do grupo de pais, eu gosto muito, porque a gente aprende, a gente vê um monte de gente, cada um fala do seu problema. O filho de um, o filho de outro. Falam dos problemas que têm em casa. Como que é o relacionamento entre eles e eu gosto! $E$ a gente conversa sobre os assuntos em casa, quando se tem tempo, a gente conversa.

Foi muito bom ela ter entrado aqui, acho que se ela não viesse na fono e na escola, ela seria uma menina doente, que ficaria num canto, não iria se desenvolver. Na escola ela está bem, pois a professora só fala que ela está 
bem. Na fono ela também está bem. Então foi a melhor coisa que aconteceu para ela.

Hoje eu quero que ela se desenvolva mais, que cresça mais e que não tenha discriminação quando ela estiver maior. Que ela arrume serviço também, porque hoje em dia, um de cadeira de rodas, outro surdo, outro não sei... é muita discriminação para esse pessoal e não pode ser assim. Ela anda, é uma menina com saúde! Ela sabe escrever bem, faz tudo certinho, na escola vai muito bem, então, eu quero o melhor pra ela e eu já falei para Célia que pai é aquele que cria, não aquele que põe no mundo.

A pessoa que mais se comunica com a Carla é a Célia porque convive mais com ela. As tias, eu não sei, nem como foi quando a Carla tinha três anos, a Cíntia, a Cilene, mas acho que não se comunicam como eu e a Célia que já estamos convivendo há bastante tempo. Mas elas não têm paciência, tem que ter paciência com criança. Com o Carlos não tem jeito. Ali tudo o que ela fala ele entende, e o que ele fala para ela, ela entende.

De resto, acho que está tudo bem, as reuniões, as aulas de sinais. 0 ruim seria se não tivesse nada, se chegasse aqui e nada.

\section{Família 4 (F4)}

A) Sr. Diego - avô da Daniela 
Meu nome é Diego e nasci no dia três do cinco de mil novecentos e quarenta. Minha neta se chama Daniela, nasceu no dia dois do sete de noventa e oito e freqüenta uma escola especial.

A primeira pessoa que percebeu que a Daniela não escutava foi meu genro. Ele quis levá-la ao médico para saber o que acontecia porque minha esposa andava preocupada e a minha filha, a esposa do meu genro, falou para levarmos ao médico. Resolvemos pagar uma consulta no Edmundo Vasconcelos e lá o médico falou para levarmos a Daniela numa fonoaudióloga e no otorrino porque podíamos ligar um avião perto dela que ela não iria escutar. E realmente. Ele nos deu o nome da Derdic para que pudéssemos fazer uma inscrição e passar por lá. Infelizmente eu só passei por lá porque quando a Derdic me chamou, a gente já estava em outra escola, em um trabalho muito bom então a gente deu continuidade, agradeci a Derdic, e preferi não freqüentar lá.

Quando a gente desconfiou que ela era surda, a Daniela tinha um ano e meio, dois anos. A gente já tinha uma idéia porque ela não falava e nem ouvia. A gente era um pouco leigo no assunto e não tomou iniciativa, mas depois foi dando tudo certo, graças a Deus.

O diagnóstico veio através do exame que foi feito, BERA, através do convênio dela. A Daniela tinha dois anos e meio e logo em seguida recebeu 
seu primeiro aparelho, que compramos. Compramos o aparelho e paguei em seis vezes um valor muito alto, $\mathrm{R} \$ 3.690,00$

A primeira vez que a Daniela foi a um tratamento fonoaudiológico ela tinha uns dois anos. Era um tratamento pago, $\mathrm{R} \$ 60,00$ a consulta, mole não.

Em casa, dificilmente a Daniela usa o aparelho dela. Ela não tem uma boa aceitação do aparelho e eu acho que ela não gosta. Ela usa, mas não gosta. Eu ainda não vi grande melhora nela com o aparelho. Eu até gosto que ela use o aparelho porque é uma coisa científica e a gente tem que aceitar. Eu gosto que ela use o aparelho, mesmo que eu não veja muita diferença na minha comunicação com ela quando ela está com ou sem aparelho.

Quando viemos para cá, sabe que a expectativa de pais é que ela viesse fazer um tratamento e viesse a ouvir, falar o mais rápido possível. E na verdade não é bem assim. Ela pode até vir a falar amanhã ou depois, mas não vai ser nunca como a gente. Mas no geral as expectativas depois que a gente ficou sabendo a realidade da coisa são boas.

A minha comunicação com a Daniela é mais por sinais porque eu entendo bem e ela também entende as respostas que eu dou para ela. Às vezes quando eu não entendo, peço para ela me mostrar o que ela está falando, se é um objeto, se é um lugar, então eu peço que ela me mostre, para eu poder chegar e entender bem o que ela quer. Com as outras pessoas da 
casa normalmente a comunicação não é muito boa e quando eles têm alguma dúvida, eles vêm perguntar pra mim. Há uma certa dificuldade, principalmente da minha esposa, que devido o trabalho dela não tem tido tempo de freqüentar uma escola, mas ela vai freqüentar agora em 2005 ela vai fazer um curso na FENEIS para poder ter uma maneira mais fácil de comunicação com ela. Já a Denise é diferente. A Denise grita muito, o que me deixa bastante nervoso. Não adianta você gritar, se você grita, está gritando para você mesmo, então eu acredito que ela também vá estudar esse ano.

Eu tive uma aceitação boa da Língua de Sinais, acho que é uma nova língua para mim, agora para ela não, é a primeira língua, então a gente tem que aceitar, quer queira ou não.

As reuniões do grupo de pais para mim são muito boas porque você sempre tem informação de como as outras pessoas receberam o problema e as soluções que cada um dá para os seus problemas. Em casa às vezes converso com a Dona Dirce. Com a Denise não, é muito difícil, a gente não tem um bom diálogo, a gente não tem diálogo. Mas para Dona Dirce passo bastante coisas... Quanto aos sinais é um pouco mais difícil porque a gente tem bastante livros em casa de sinais e ninguém tem a preocupação em pegar para poder ver. Quer dizer, a minha esposa não tem tempo e a Denise não se interessa. Não adianta a gente chegar aqui pra mentir. Tem que dizer a realidade. E não é com mentira que eu vou te convencer. Acho que ela que tem que se convencer que precisa estudar. 
Desde que nossa família começou tratamento, a nossa família mudou muito. O relacionamento meu com a Daniela, o entendimento, aquela preocupação que a gente tinha de que seria uma doença, já não existe mais. Eu acho que teve uma melhora muito grande.

Hoje a minha expectativa é de que amanhã ou depois, a Daniela vai se desenvolver cada dia mais, como ela já vem se desenvolvendo. Está bem mais calma, e que ela siga um caminho. A gente tem um compromisso com ela de no próximo ano ajudar muito na questão escolar, porque ela tem que desenvolver, principalmente na escrita e na leitura, para que possa dar uma seqüência na série da escola, para que não fique muito amarrada na escola. Existem crianças que ficam dois, três anos no prezinho, no primeiro e a gente não tem vontade que isso aconteça com ela. A gente quer que ela se desenvolva. A gente vai fazer o máximo, ajudar para que ela se desenvolva.

B) Dona Dirce - avó da Daniela

Meu nome é Dirce e nasci no dia trinta do quatro de cinqüenta e dois. A minha neta se chama Daniela, nasceu no dia dois de julho de noventa e oito. A Daniela estuda no Rotary. É uma escola boa aparentemente, ela vai com o avô, pelo o que ele passa pra gente. Eu já conversei com a coordenadora e achei ótimo, é uma escola especial para crianças surdas.

Foi a minha filha mais velha quem primeiro desconfiou de que a Daniela era surda, quando ela tinha um ano e cinco, seis meses. Ela 
freqüentava a fono, só que até então a fono falava para gente que ela estava com a fala retardada ainda e que era para gente ter paciência. Mas a gente em casa, com exercícios como bater palma para ver se ela ouvia, chamar, percebia que ela não reagia.

Nós, então, pedimos uma audiometria. Nós que pedimos, não a fono e foi aí que descobrimos. A Daniela deveria estar com mais ou menos dois anos. A Daniela já freqüentava fono desde que ela tinha mais ou menos um ano e quatro meses porque ela não falava. Nós percebemos e levamos, mas a surdez só foi descoberta, eu acho que, muito tarde. Quando ela tinha quase dois anos.

Quando a Daniela tinha por volta dos dois anos, logo que tivemos a notícia, já começamos a nos preparar e compramos o aparelho. Ela, até usa o aparelho em casa, mas ela não gosta e não é sempre que ela usa não. Ela usa muito pouco e ela não gosta. Eu acho que quando ela está com o aparelho, ela fica muito inquieta. Ela não aceita, acho que ela tem que ficar a vontade. Acho que o importante é a gente se comunicar com ela porque o aparelho pouco ajuda e eu acho que sem o aparelho, ela se comunica mais.

As nossas expectativas ao procurar atendimento aqui eram de um socorro mesmo, porque a gente esperava uma criança normal e de repente vem uma criança surda. A gente não tinha noção de nada, era nula e graças a Deus tudo o que a gente esperava está alcançando. As aulas de sinais, que 
mesmo eu não podendo acompanhar, meu marido está, e ele passa para gente muita coisa que aprende aqui. Acho que ela está sendo muito bem tratada. Acho que está muito bom.

Quando vou conversar com a Daniela, muitas vezes ela me ensina algumas coisas porque mesmo eu não freqüentando as aulas de sinais, eu procuro em alguns cursos que eu faço pela Prefeitura, mas é por falta de tempo, então tem que ser assim mesmo, na hora d'eu me comunicar com ela, muitas vezes eu faço sinais errados e ela me ensina, fala que está errado, então eu acho que eu me comunico muito bem com ela. Eu procuro até fazer sinais. Muitas vezes eu falo e ela entende, mas mais de observação mesmo. Ela observa muito a gente. Ela lê os lábios da gente, porque até então a gente, eu mesma não sei língua de sinais.

As outras pessoas de casa se comunicam da mesma forma. A minha filha, Dulce, entende mais e até se comunica mais com ela. O Diego mesma coisa, ele entende mais, o pior acho que é comigo mesmo, pela falta de tempo, eu não estou sabendo mesmo a Língua de Sinais, é pouquíssima coisa. A Denise agora, já entende mais, ela já se comunica mais, com sinais.

A minha aceitação pelos sinais foi normal. Acho que é a primeira língua para ela se comunicar, então a gente tem que aceitar. Tem que fazer mesmo até para ajudá-la. 
Do pouco que eu freqüentei as reuniões do grupo de pais, achei dez. Achei o pessoal muito comunicativo, procurando ajudar o outro, acho que até apoiando, porque muitas vezes, como quando eu comecei aqui com o Diego, eu vinha nas primeiras vezes, eu ficava meio assim porque a gente não aceita e acho que tivemos muito apoio dos pais, acho muito bacana.

O Diego conversa muito, tanto comigo quanto com a Denise sobre as coisas do grupo, apesar da Denise não aceitar. Ela acha que a Daniela vai falar, mas ele comenta sim, fala das palestras, dos encontros que tem, ele passa também um pouco dos sinais para gente, passa sim.

Desde que começamos aqui mudou bastante coisa na minha família, acho que até a aceitação da Daniela como ela é, mudou. Mudou muito sim. A gente não aceitava e agora, através dos sinais, a gente está se comunicando com ela. Eu acho que isso aí já quebrou aquele muro que tinha, da gente não aceitar a Daniela surda, agora a gente se comunica com ela.

Hoje as expectativas são da gente estar aprendendo mais para poder ajudá-la e quebrar esse muro que ainda não está totalmente quebrado. Ainda tem alguma coisinha para gente descobrir do outro lado, para gente poder ajudá-la, eu acho que é isso aí.

Eu queria é agradecer vocês por serem as pessoas, sabe, atenciosas, todas, você principalmente, apoiando, orientando a gente, acho que é isso. 
C) Denise - mãe da Daniela

Meu nome é Denise e a data de meu nascimento é vinte e um do doze de oitenta e um. Minha filha se chama Daniela, sua data de nascimento é dois do sete de noventa e oito e ela estuda no Rotary, que é escola especial de crianças surdas.

A minha irmã foi a primeira pessoa que descobriu que a Daniela era surda. A Daniela não balbuciava nada. E a minha irmã sempre falou que ela era surda e a gente não aceitava, até que a minha mãe falou para levá-la em uma fono. A Daniela passou por fono e a fono também não descobria. $E$ foi passando de fono em fono, até que teve uma que pediu uma audiometria de tronco cerebral e então se detectou que ela era surda.

Eu não sei exatamente, mas acho que a Daniela tinha um ano e cinco meses, quando a gente começou a desconfiar e uns dois anos quando tivemos a confirmação. A primeira vez em que ela foi a fono ela tinha mais ou menos um ano e cinco meses.

O aparelho, nós compramos, mas eu não tenho a data certa. Ela está com seis anos, acho que ela deveria ter uns quatro anos, eu acredito que é isso.

Em casa é muito difícil dela usar o aparelho. Mesmo assim, a gente tenta colocar, ela fala que não, que ela só coloca na escola, em casa é muito 
difícil mesmo. Eu acho que ela não gosta do aparelho. Ela fala que incomoda, que dói.

Eu vou falar a verdade, é como eu falo para minha mãe, ela coloca o aparelho, mas parece que ela não escuta. A gente conversa com ela, chama, fala alto, ela nem "tchan" pra gente. Então acho complicado falar. Não sei se é porque ela ainda não entende porque que ela está com aquilo, mas eu procuro deixar sempre com ela, mas é muito difícil mesmo. E mesmo quando ela está sem o aparelho, a minha comunicação com ela é a mesma.

Quando entramos aqui na USP a expectativa era de que ela falasse rápido, mas tudo tem que ser aos poucos. Minha expectativa era que ela fosse falar bem rápido.

Hoje para a nossa comunicação, eu falo. Eu não gosto, eu não aceito, essa é a verdade, não aceito a Daniela desse jeito. É muito difícil eu falar em Língua de Sinais com ela, muito difícil mesmo. Eu falo mais e ela entende tudo o que eu falo, como eu entendo as coisas que ela fala. Às vezes eu me comunico com Língua de Sinais, mas é muito difícil, é mais falando. Eu não sei te dizer bem a forma, mas eu sei tudo o que ela faz, tudo o que ela quer falar, passar para gente, a gente sabe e ela sabe a mesma coisa da gente. Quando a gente quer alguma coisa dela, ela já sabe. Acho que foi criado isso desde quando a gente descobriu. 
Meu pai se comunica mais com Língua de Sinais. A minha mãe, mais ou menos, porque ela não sabe muito. O que ela sabe é o que é passado para ela, mas quem comunica mais com ela em Língua de Sinais é meu pai, o resto é tudo assim, a gente passa algumas coisas para ela em Língua de Sinais, mas é mais falando.

Voltando um pouco, não é bem a Língua de Sinais que eu não aceito, é mais por ela ser surda. Eu não consigo aceitar, eu não consigo. Eu vejo que pode até ser egoísmo da minha parte, eu sei, mas é tão difícil aceitar que sua filha é surda, é muito difícil. Eu não consigo, não consigo, ainda não aceito.

Quanto às reuniões do grupo, eu não costumo freqüentar, mas pelo que eu já freqüentei, acho que é bom. Acho que as pessoas falam tudo o que elas pensam, o que está certo, o que está errado, dão opinião. Pelo que eu já freqüentei há bastante tempo, eu achava bom, mas pelo que meu pai fala é muito bom, com certeza.

Eu não converso com o meu pai, eu não falo com ele, mas assim quando é alguma coisa para passar, ele passa. Quando vai acontecer uma coisa, ele fala, tudo ele passa. A gente não tem uma convivência de conversar, como a gente está conversando, mas tudo o que tem, que acontece, tudo o que tem que ser passado, ele passa. 
Desde que começamos a fazer o tratamento aqui mudou muito, mudou tudo, porque foi onde ela começou. Tudo mudou, de ruim para ótimo porque a Daniela desenvolveu muito. A Língua de Sinais, ela aprendeu foi realmente aqui e a nossa expectativa é aqui em vocês, assim como vocês têm da gente.

Hoje, o que eu espero, é egoísmo, mas eu espero que a minha filha fale. Que ela aprenda a falar rápido, ou então que domine bastante a língua de sinais, espero isso.

\section{Família 5 (F5)}

A) Eliana - mãe do Eduardo

Meu nome é Eliana e nasci no dia nove do dez de setenta e nove. Meu filho se chama Eduardo, nasceu no dia onze do cinco do noventa e seis e estuda em Escola regular de sala especial.

Eu e meu marido fomos os primeiros a perceber que o Eduardo não escutava. Ele tinha mais ou menos um ano, mas a gente ficou esperando. Percebemos mas não queríamos aceitar. Nós ficamos esperando, esperando até pedirmos para médica. Aí fomos e vimos que tinha mesmo e ele já ia fazer três anos.

Assim que ele fez o exame, nós estávamos naquela ansiedade e já compramos o aparelho, conseguimos comprar e ele já colocou com três aninhos. O Eduardo gosta do aparelho porque ele diz que ouve e sem, ele diz 
que não tem nada. Ele usa o dia todo e só tira pra dormir. Desde que eu comprei, eu o incentivei a colocar, mostrava para ele que era bom, eu sempre incentivo ele.

Quando ele está de aparelho, ele presta mais atenção no som que está saindo da boca, sem aparelho ele só olha para as mãos. Com aparelho ele já presta mais atenção na boca mesmo.

O Eduardo começou tratamento fonoaudiológico aqui na USP, quando ele tinha três aninhos. E quando começou, eu tinha todas as expectativas. Eu tinha a preocupação, porque eu pensei que só o Eduardo era surdo, mas depois que eu vim para cá, achei todas porque já achei o grupo de pais que me deu esse apoio todo. Era mais isso mesmo, essa preocupação.

Eu esperava que ele fosse se ajeitar na sociedade, ter a parte social, aprender a diferença de que ele não está no mundo do ouvinte, a distinguir, separar e foi o que ele aprendeu mesmo.

A nossa interação se dá mais por sinais, apesar de que eu não consigo só fazer os sinais. Eu vou falando e fazendo os sinais, mas a gente se entende muito bem. Não existe nenhuma estratégia criada. Se deixar, o Eduardo não para de falar. Toda hora ele chama e agora com esse aparelho novo, ele está mais ansioso, tudo o que ele escuta ele quer saber e quer ver. Eu nunca tive problema para me comunicar com ele 
Com o meu marido, você vai ver. Olha, lá em casa como somos só nós três, o Elcio tem um pouco de dificuldade porque ele não aprende, não tem muito tempo também, mas é de acordo comigo mesma. Ele pergunta como é que faz isso, como é que tem que falar aquilo, aí eu vou ajudando, porque ele sozinho é meio difícil. O Eduardo vai apontando porque é difícil.

A Língua de Sinais, como eu vi que era o jeito eu não tive problema nenhum, até gostei. Não tive nenhum problema até hoje.

Quanto às reuniões do grupo de pais, no meu ponto de vista é bom porque quando a gente está há muito tempo, a gente começa achar que já é besteira, mas no começo, para quem está começando, é aquele incentivo, é tudo o que a gente precisa na hora. Depois vai passando o tempo e a gente está vendo que já viu isso mais de mil vezes, mas para quem está entrando, aquilo lá já é um ponto de esperança. Eu vejo desse jeito.

A maioria das vezes, quando o Elcio já não dorme e ainda escuta, eu conto as coisas que aconteceram.

Em casa mudou tudo depois que começamos o tratamento porque antes nós éramos nervosos. O Eduardo pedia as coisas e ninguém entendia. Mandava apontar e ele já vinha para cima, queria bater, mudou tudo. Agora ele, apesar de ainda ser bem bagunçado, mudou tudo, porque ele está bem mais calmo, sabe sinais, está aprendendo a soltar alguns sons, mudou tudo. 
Hoje as minhas expectativas, é que eu acho que o Eduardo ainda tem chances de evoluir bastante, a começar até a falar, porque ele já faz bastantes sonzinhos. O meu ponto de vista é que ele evolua bastante para facilitar a vida.

B) Elcio - pai do Eduardo

Meu nome é Elcio e nasci em vinte e nove do onze de sessenta e cinco. O nome do meu filho é Eduardo, nasceu em onze do cinco de noventa e seis e freqüenta uma classe especial em escola regular.

A descoberta da surdez do Eduardo foi de ambos, tanto eu quanto a Eliana suspeitávamos, mas até fomos induzidos um pouquinho pelo médico pediatra que sempre falava que era normal, normal, normal. Até que resolvemos procurar outro, resolvemos tentar um outro meio, porque desse jeito não estava muito certo. Ele não falava, fazia movimentos, mas não tinha som nenhum e aí começou a batalha. Nós começamos a desconfiar porque ele realmente não reagia aos estímulos, não percebia os sons, nada, e foi então que percebemos que tinha alguma coisa errada, ele tinha um ano mais ou menos.

Quanto ao diagnóstico efetivo, eu estou com um pequeno problema de recordar datas, porque eu tive no ano retrasado um pequeno derrame que me afetou a questão de lembrar datas. Eu estou recuperando, mas é um negócio lento. 
O Eduardo tinha três anos quando recebeu o primeiro aparelho. Para esse a gente fez o seguinte: a gente comprou um aparelho e o outro, os amigos do trabalho se reuniram e a gente conseguiu o valor para adquirir. Agora quanto ao tratamento de fono eu infelizmente não consigo te precisar não.

O Eduardo usa aparelho em casa e ele não tem reclamado nada. Ele quando está com aparelho é como se ele estivesse normal, assim, sem nada. A única coisa é quando ele deita do lado e o aparelho apita. Ele fica apitando, apitando, até a gente chamar e pedir para ele desencostar a cabeça.

Eu prefiro que ele use o aparelho, mesmo. Prefiro que use porque com o aparelho ele tem a possibilidade de ouvir mais sons. Não tem porque a gente querer proibir. Quero mais que ele use mesmo para sair para tudo quanto é lugar.

A minha comunicação com ele, eu não tenho sentido diferença não quando ele está com e sem aparelho. Ele fica olhando para gente e se por exemplo eu falo com ele, se é coisa assim básica, ele praticamente faz as coisas, eu não vejo diferença. A gente conversa um pouco por sinais e fala. A comunicação efetiva-se, eu entendo bem, ele entende bem, não estabelecemos nada. 
A Eliana usa bastantes sinais porque ela sabe bastante e então ela é mais por sinais, mesmo. Falar, é pouca coisa. Ela fala, mas é mais por sinais mesmo. E sempre acontecem momentos assim: você vai falando, acha que a criança é ouvinte e você acaba falando e espera que dê resultado, não tem jeito. Aí tem que ser nos sinais mesmo, não tem jeito.

Quando ele entrou aqui eu tinha a expectativa era de que um dia ele viesse a falar. Essa era a maior expectativa. Quanto aos sinais, na minha opinião, aceito numa boa porque não tem opção. Como se diz, é a língua que tem mesmo para ele se comunicar. Não tenho nada contra, é até legal, agora que está mais estabelecido, tem esse dicionário, tem tudo, está mais certinho, é tranqüilo.

Eu vim poucas vezes às reuniões dos pais, mas eu acho legal porque cada um comenta as experiências, e vai enriquecendo, vai fazendo com que a pessoa consiga saber lidar com os momentos novos que surgem, dúvidas, esse negócio é legal, vai esclarecendo devagar. Eu posso te falar pelo que eu participei e pelo que a Eliana comentou. Ela conversa tudo, fala que sempre está a par do que está acontecendo.

O Eduardo melhorou bastante, primeiro que ele está com mais calma, devagar está desenvolvendo bem e está sendo bem proveitoso mesmo. 
Hoje, o que eu quero mais é que ele cresça, que ele consiga estudar, porque eu vejo que hoje em dia, não tem limitações no campo de trabalho. Tudo é questão de estudar. Tem que ter também o esforço dele. Depois ele vai crescendo e o que a gente puder fazer, a gente vai apoiando devagar, para ele não ter problema nenhum. Tem que dar força, não tem outra saída, não adianta você querer abandonar a criança numa hora dessa. Tem que simplesmente dar força. A Eliana está querendo fazer um curso na FENEIS também, dou todo o apoio. Quer fazer? Melhor. Bom para ela, bom para o Eduardo, bom para gente.

\section{Família 6 (F6)}

A) Fernanda - mãe do Fábio

Meu nome é Fernanda e nasci no dia seis de janeiro de meia quatro. Meu filho se chama Fábio., nasceu em catorze de março de noventa e nove e estuda em uma escola especial pra surdos no Jardim Sipave em Osasco.

Fui eu quem primeiro percebeu que o Fábio não escutava. Eu desconfiei quando ele já tinha uns cinco meses e a princípio ninguém aceitou. Eu, já de início pedi para o médico, o pediatra, mas ele não queria dar o encaminhamento para fazer o exame. Eu insisti, insisti e então com dez meses foi feito realmente o exame e constatou que ele era surdo

A descoberta para mim foi um choque, mesmo eu já desconfiando. $O$ Flávio falava que não, que era coisa da minha cabeça, que estava certo, mas 
eu achava que ele escutava pelo menos um pouco de um ouvido. E percebi que não era normal, para mim foi um choque muito grande, eu chorei muito. Acho que o primeiro baque, a gente sente muito.

Quando o Fábio tinha um ano e três meses ele recebeu por doação o primeiro aparelho, no hospital de Bauru, na USP de Bauru. E Já quase em seguida, eu acho que ele tinha um ano e cinco meses, um ano e seis meses, ele começou terapia fonoaudiológica na PUC, na Derdic.

O Fábio usa aparelho em casa e ele gosta porque às vezes a gente sai correndo de casa, e quando ele chega na casa da minha mãe, ele pede: -Cadê o papapa? Daí a minha mãe já coloca, e às vezes ele mesmo coloca. Então a gente percebe que ele sente falta. Ele usa o dia inteiro. Só tira para tomar banho. Às vezes quando ele está meio doente e ele não quer usar, ele mesmo tira, mas geralmente é o dia inteiro.

Eu gosto que ele use o aparelho, eu acho que para se comunicar fica mais fácil. Às vezes ele está longe e eu chamo, ele atende, e sem aparelho fica difícil, eu tenho que ficar correndo atrás, chamando. Eu prefiro quando ele está com o aparelho. E a comunicação se altera quando ele está com o aparelho, pois geralmente além dos sinais eu falo, mas é porque eu prefiro mais a oralidade. E quando eu chamo, ele atende. Se está no meio de barulho, eu falo um pouco mais alto para ele me escutar e geralmente ele atende. 
Quando eu vim para USP, eu queira que melhorasse a fala dele, porque ele já fala bastantes coisas, mas ele fala coisas erradas e o /r/ e o /s/ ele não fala, então quando ele fala /porta/ ele fala /pota/. Eu vim mais procurando mesmo melhoria.

A gente conversa tanto em Língua Oral quanto em Língua de Sinais. Ao mesmo tempo em que vou fazendo sinais, eu vou falando. Às vezes ele faz só o sinal e o que eu não sei, eu pergunto para ele o que é e ele acaba falando. Fala meio errado, mas dá para entender o que é. Às vezes tem sinal que ele usa, que ele aprende na escola e eu não sei, daí eu fico perdida e ele pega e fala para mim o que é.

A nossa comunicação é natural. Ele conta as coisas e eu vou falando com ele. O que eu percebo muito é que ele gosta que você fique olhando para ele. Se você não olhar, ele não fala, então ele fica chamando, chamando, chamando, até você olhar, enquanto você não olha, ele não fala, seja por sinais, ou via oral mesmo, ele fica chamando até você dar atenção para ele. Acho que é um jeito dele achar que você está prestando atenção realmente e não só escutando por escutar.

Em casa as pessoas se comunicam com ele da mesma forma. É mais oral, minha mãe, ela não sabe muitos sinais, então ela fala muito com ele, e quando ela vê que ele fez algum sinal diferente, ela me pergunta o que é e eu explico. Se eu sei, eu explico. Às vezes ele inventa sinais também, daí eu falo 
que eu não sei o que é (risos). Ele gosta muito de inventar. Ele inventa e eu falo que eu não sei, daí eu pergunto para ele, ele fala o que é e aí eu falo:- oh não é assim, é de outra forma...

Eu aceitei a Língua de Sinais rápido. Comecei a pesquisar e a ver o que era, que é a língua deles mesmo, então para mim foi uma aceitação rápida, aprendi fácil, não sei tudo, mas o que eu não sei eu tento aprender, mas eu gosto, eu gosto dos dois.

Quando eu vim para cá eu não sabia que tinham essas reuniões, eu até comentava com o pessoal do serviço que sempre tem atendimento para os surdos, para os filhos, mas não tem para os pais. E eu gostei muito daqui, eu acho que querendo ou não você acaba assimilando alguma coisa que uma outra pessoa fala, te serve de ajuda, de apoio, você sabe que não está sozinho, tem outras pessoas que passam pela mesma coisa. Tem uns que tem filhos com mais idade e você já pega alguma coisa, e fala que lá na frente vai precisar disso, ou daqui a pouco eu vou usar. Então eu gosto do grupo de pais, eu assimilo bastante coisa, apesar de que eu sou mais de ouvir do que falar.

Na maioria das vezes eu converso com o Flávio sobre as coisas do grupo. Quando acontece alguma coisa e ele chega mais tarde ou acaba surgindo alguma coisa, porque o Fábio também não dá muita trégua, ele fala pelos cotovelos, falo que ele teve a quem puxar, mas (risos) geralmente a gente conversa, o que se passou, o que não passou, como é que tava o grupo. 
Apesar de que ele não me fala muitos sinais porque ele esquece a maioria (risos) e eu falo: -o que você aprendeu hoje? Aí ele fala:- peraí deixa eu pensar... aí ele me fala um sinal, daí ele fala :- não lembro o resto... (risos) então tá, tá bom.

Desde que começamos aqui na USP eu acho que muita coisa mudou, eu acho que melhorou. Eu percebi que o Fábio fala muito mais coisas do que ele falava. É lógico que é um processo longo, não é de agora, já está vindo há muito tempo. E o relacionamento ficou mais calmo, estava muito perturbado, muito agitado. É que houve uma série de mudanças também, nós saímos da casa da minha mãe, então acho que ficou mais calmo e eu acho que o relacionamento melhorou.

Hoje o que eu espero é que ele melhore cada vez mais, eu acho que ele tem um potencial grande, ele gosta de ouvir, pelo menos ele gosta de usar o aparelho, porque a gente percebe. Eu acho que a minha expectativa é só aumentar cada vez mais a fala dele. Quanto ao grupo de pais eu gosto muito, e eu acho que a tendência é cada vez melhorar mais o relacionamento, não só com o Fábio, com o meu marido, mas com os outros, porque só quem tem um filho surdo sabe o que é. A pressão é muito grande, não só dos familiares mas também das outras pessoas, pois você batalha, batalha e às vezes você não consegue as coisas, então o grupo de pais para mim está sendo muito bom, e a expectativa é que continue assim cada vez melhor. 
B) Flávio - pai do Fábio

Meu nome é Flávio e nasci no dia onze de abril de cinquenta e cinco. Meu filho se chama Fábio e nasceu no dia treze de março de noventa e nove. Ele tem cinco anos.

Atualmente ele freqüenta a escola da Prefeitura Municipal de Osasco, uma escola especializada em crianças com surdez, com deficiência auditiva. Uma escola especial porém além de atividades de jardim da infância, ele tem uma vez por semana acompanhamento com uma fono também.

É difícil avaliar quem primeiro percebeu que ele não escutava, porque eu não lembro, mas eu diria que fomos nós dois, foi quase que simultâneo. Primeiro porque fazíamos alguns barulhos e inclusive barulhos da rua e começamos a perceber que ele simplesmente não acordava ou não se assustava com nada, então começamos a desconfiar. Com menos de seis meses nós já estávamos correndo atrás disso, para se fazer um BERA.

A princípio para minha esposa, até hoje quero dizer, ela já superou algumas fases mais negativas, mas para ela foi muito duro. Eu sou uma pessoa meio dura, eu não me abalo com certas coisas. Eu acho que se ele tivesse um outro problema, não sei, a gente nunca pode falar: eu não gostaria de ter um filho paraplégico ou com problemas mentais, mas em um primeiro momento eu logo lembrei desses problemas, então, eu falei: - poxa, tudo bem, é complicado. Eu não pensei no meu futuro, no futuro dele. Porque é evidente 
que a família acaba tendo uma carga extra. Agora minha esposa, ela não ficou magoada comigo ou revoltada com o mundo, mas foi uma mágoa muito pessoal, ela não externou isso, mas a gente foi devagarzinho convivendo e estamos convivendo com isso. E está ótimo, porque ele é uma pessoa muito inteligente e vocês que estão dando esse apoio.

Com o BERA tivemos alguns problemas porque devido a idade, alguns laboratórios falavam que não podiam fazer. Eu acho que com encaminhamento e tudo ele tinha entre seis e oito meses. E ele recebeu o aparelho quando ele tinha um ano e alguns meses. Nós conseguimos o primeiro aparelho por doação da empresa onde minha esposa trabalha. E depois a USP de Bauru também fez uma doação.

Com uns dois anos o Fábio começou terapia fonoaudiológica no Derdic e ele freqüentou lá por dois anos, não, acho que ele começou com três anos.

O Fábio usa o aparelho constantemente. Eu diria $90 \%$ ou $95 \%$ do tempo que ele está ativo, ele usa o aparelho e nós também sempre chamamos a atenção dele para ele colocar e ele mesmo já coloca o aparelho. E ele gosta do aparelho, gosta porque, eu por exemplo gosto muito de ouvir música e eu sempre quero que ele participe. Não só música de criança, porque o surdo na idade dele, que está ainda fazendo algumas descobertas, não sei se ele identifica muito se é música de criança ou não. Eu por exemplo gosto de música barulhenta, então ele está aprendendo a curtir as minhas músicas. Se 
ele não põe o aparelho ele não vai ouvir tudo, então ele tem tomado iniciativa. Às vezes eu vou ligar o som e ele está sem o aparelho, ele vai lá e pega o aparelho. É raro ele estar sem o aparelho. E eu gosto que ele use o aparelho porque apesar de não ser um som perfeito, eu imagino, porque nós como não somos surdos não temos idéia do que ele ouve, mas alguma coisa ele ouve e ele tem uma relação com esse sinal através desse aparelho e eu acho que está sendo bom.

Quando o Fábio está com o aparelho eu procuro falar mais com ele. Evito os sinais, apesar de que aqui foi a oportunidade, aqui na USP, com vocês, de estarmos tendo contato com Libras, o que nós não tivemos no Derdic. Não que eu esteja falando mal do Derdic, mas aqui acho que é um pouco mais completo. Aqui está melhor do que lá. Mesmo a gente aprendendo aqui, às vezes te dá um branco, você não sabe fazer um sinal. Então eu prefiro quando ele está com o aparelho porque ele pode responder, mesmo porque quando ele não responde, eu vou lá e pego no pé dele: - olha, por que você não está ouvindo? O aparelho está ruim? Por que você não ouviu papai falar? E minha mulher age da mesma maneira e é ela quem troca a pilha do aparelho. Ela tem um teste. O Fábio também dá um sinal: - a pilha está ruim. Aí ele chama a atenção da mãe, ele também ajuda a fazer a manutenção. A relação dele é bem grande com o aparelho. Ele sabe quando a pilha está ruim, ele já sabe por lá no testador, mas ele fala para mãe: oh, a pilha está ruim. E a questão de limpeza, aí já não é muito com ele, mas a minha esposa sempre está olhando. 
Eu vim procurar atendimento aqui, primeiro pela questão da distância, o local que eu trabalho e que a minha esposa trabalha, são totalmente opostos e coincidentemente como ele fica mais na casa da minha sogra, que é aqui próximo a USP e fica no meio do caminho. E lá no Derdic era meio complicada, essa parte de locomoção, porque pegávamos um trecho com muito trânsito, e sacrificava boa parte do horário do trabalho. Por outro lado começamos a ouvir algumas pessoas que já conheciam a USP e fomos meio que fazendo uma pesquisa, fomos sondando a coisa, até que um dia, minha esposa encontrou no ônibus, o esposo da Julia, o senhor José, e eles conversaram e ele a incentivou a vir aqui. Ela veio, me trouxe, fizemos algumas entrevistas, sempre fomos bem atendidos e depois que conhecemos o trabalho, eu estou tirando o chapéu, porque acho que aqui, eu e ela temos atividade tanto na segunda quanto na quarta feira, tem reuniões, tem as aulas de Libras, nós não ficamos olhando, ou batendo papo furado no saguão, esperando o Fábio sair da aula dele. Enfim, eu acho que aqui está sendo mais proveitoso para família, para o Fábio , para o pai, para a mãe. E essas reuniões no relacionamento de pais e filhos surdos, que nós não tínhamos lá no Derdic, então achei um pouco melhor.

Eu esperava, eu não estou aqui para falar mal do Derdic, mas eu esperava pelo menos que ele tivesse continuidade daquele trabalho que era feito no Derdic, que também não era um mau trabalho. A linha de tratamento dele lá era fala, fonoaudiologia mesmo, não Libras. Aqui na USP também tem oralidade, então era o caso, mas lá no Derdic você tem duas opções, ou você 
escolhe oralidade ou Libras, então desde o princípio nós escolhemos oralidade para ele porque nós sabíamos que de uma maneira ou de outra, a Libras ia começar a acontecer, inclusive conosco, não tem como evitar, porque mesmo antes dele ir para o Derdic, com dois anos de idade nós já tínhamos começado a instituir alguns sinais em casa, que não eram os sinais universais, mas que você sabe que alguns sinais são bem íntimos, só da família. Então a expectativa era de dar continuidade ao trabalho que já era feito no Derdic, isso absolutamente sem fazer comparação, eu acho que ele está indo bem aqui também. Ele se dá bem com a com a fono que trabalha com ele. A expectativa era essa.

Eu procuro sempre falar com ele, quando eu não consigo, eu tento fazer Libras e às vezes eu faço errado e ele me corrige. Ele fala: -você precisa aprender! é isso. A gente não tem assim longos papos, mas a dependência maior dele, o contato maior dele é com a mãe em casa, mas meu contato com ele também é excelente, principalmente quando ele está só comigo, aí ele não tem no que se agarrar e ele tem que manter um bom relacionamento comigo, mas eu não tenho dificuldades para me comunicar com ele. Não há nenhuma estratégia especial. Às vezes a gente fica meio nervoso com ele assim, não nervoso, sério! Justamente quando ele está com aparelho e você o chama, você precisa falar, ou ele está fazendo alguma coisa errada e ele não dá atenção. Aí eu vou até ele e toco nele. - olha você não está me ouvindo? Poxa você está fazendo uma coisa errada, olha, e eu estou querendo conversar com você, você pode me dar um tempo? Coisas desse tipo, mas não tem 
estratégias muito especiais. Agora quando ele está de mau humor, ele mostra a língua, ele dá sinais de que não quer conversar sobre aquilo ou não quer conversar.

A avó fica com ele uma parte do dia, não toda parte do dia, uma pequena parte e ela sabe muito pouco de Libras, então eu acho que a comunicação com ele é mais na fala mesmo, é meio rotina lá, com a avó. O contato dele fora da USP e fora da escola da Prefeitura é pequeno e justamente aqui na USP está sendo uma oportunidade e com essas reuniões que tem entre os pais, da gente estar se aproximando mais, começar a ir na casa do outro, marcar reuniões mais a miúde, mais freqüentes, eu acho que isso é importante, essa relação, para ele começar a ter contato pós-escola, pós terapia da USP, pós família. O relacionamento dele com outras crianças é bom também, com crianças ouvintes, e eu vejo que às vezes ele fica aflito. Quando vê uma criança, ele nem sabe se é surdo ou não, mas ele logo quer ir fazer contato com essa criança. Ele vê a outra criança como uma criança mais ou menos da idade dele e ele quer manter um relacionamento normal, comum.

Eu tenho algumas dificuldades com a língua de sinais, eu confesso, porque existe um ditado que fala "Sabão em cabeça de burro velho demora mais para espumar", eu não sou uma pessoa velha, tenho capacidade de aprender, mas ainda tenho dificuldade em lembrar alguns sinais, tanto é que o Fábio fala que eu não aprendo, que eu preciso aprender o certo. Eu sou uma pessoa meio desprovida de certas coisas, eu não choro quando alguém morre, 
eu não tenho muita dó das pessoas porque eu não quero que ninguém tenha dó de mim, eu não quero que ninguém tenha dó do meu filho, porque eu não tenho dó dele. Nós o aceitamos dessa maneira e não tinha como não aceitar, ele é meu filho.

Eu sou desprovido de certas coisas, eu sou um cara assim meio duro de coração, não sou uma pessoa muito sentimental com certas coisas. Eu sou uma pessoa super sentimental, eu choro com facilidade, eu me emociono com pequenas coisas, mas eu sou um cara meio duro com coisas que estão aí na vida, igual a morte. As pessoas pintam a morte tão feia, eu já nem ligo, eu não sei o que é chorar quando alguém morreu, meu pai morreu, não estou falando isso para dizer: -esse cara aí é forte. Não é isso, é que eu não vejo a coisa dessa maneira, eu acho que a morte, por exemplo, já que estamos falando disso, eu estou falando, eu acho que é uma outra etapa da vida, porque começou tudo de uma maneira. A concepção, o nascimento e a tua vida e a tua morte, depois de lá ninguém sabe. Eu também não quero me aprofundar nisso mesmo porque não é a minha área. Então aceitar esse tipo de problema eu encaro mais ou menos dessa maneira. Tem pessoas que:- puxa, por que Deus fez isso comigo? Será que eu tenho que carregar essa cruz? Mas por que, cruz? Porque eu acho que não tem nada a ver, eu nunca pensei nesse aspecto, nem eu nem a minha esposa, de dificuldade de ter que aceitar ou não aceitar. É a vida. Nós não temos recalques por causa disso, nem com amigos, nem com ninguém. Todos os nossos amigos o recebem muito bem, tratam ele normalmente, alguns amigos que ele ainda não conhece, a gente pede para 
tratar ele normalmente. Ele não pode se sentir diferenciado, por conta disso ou excluído.

Eu cheguei agora, nesse ano aqui no grupo, mas como eu comentei na última reunião que tivemos. Eu até fiz uma ressalva que uma das mães foi meio infeliz numa colocação. Eu acho que ela não queria falar aquilo, mas acabou falando e ela se envolveu com o que falou e de repente ficou meio complicada. Claro, sai algumas bobagens, exatamente como essa, mas às vezes de bobagens sai coisas que você acaba aproveitando e eu acho que as reuniões são legais porque essa troca de informações, como é que a família está aceitando, os amigos, como é que está sendo, porque não adianta você chegar aqui e só pra te agradar, falar que está tudo ótimo, está tudo bem, eu não tenho essa postura. Se eu estiver descontente, um dia eu vou te chamar e falar que eu acho que isso aqui não está bem.

Eu acho que essas reuniões são, justamente, muito boas porque aqui nós podemos discutir algumas coisas e levar para vocês:- olha, eu acho que não está legal, vamos tentar mudar? O que vocês acham de mudanças, etc. Assim como foi sugerido, eu não sei qual era o tamanho do grupo, para ver se fazia um grupo só, mas a Ida falou que justamente esse grupo foi fragmentado, foi dividido em dois por conta da falta de salas e profissionais no mesmo horário para atender as crianças, mais as crianças, porque eu diria que até para se voltar a um único grupo seria possível. O problema são os profissionais. Aí é complicado, aí é mais despesa pro Estado. Mas é isso e eu 
acho que tem pessoas que ainda reclamam. Eu vou falar para você, a nossa despesa com o Fábio ao nível de educação, é praticamente é zero, e ainda tem pessoa que reclamam, estão fazendo de graça, vocês estão se empenhando, está certo que vocês ganham, ganham do Estado, mas tem pessoa reclama de barriga cheia, é o que eu tenho notado às vezes, mas devagar a gente também vai falando para essas pessoas que não é por aí, que eles têm que ver que o governo não tem só esse problema aqui, tem outros.

Em casa eu converso com a Fernanda sobre as coisas do grupo, com certeza, os principais. Porque sempre sai alguma coisa que não se aproveita, mas as coisas principais a gente sempre conversa a respeito, ela está sempre ciente. Não sei se você percebeu, cada dia vem um, então nós podemos ter uma certa integração também. Existe uma troca de informações entre eu e ela. Mas uma coisa que eu acho que não está acontecendo. Eu estava vindo mais às segundas feiras, então eu tinha aula de Libras lá com a $M$, então muitos sinais eu não estava passando pra ela. Eu confesso que isso realmente é uma falha. Sempre tem falhas. Como ela conhece alguns sinais que eu não conheço, eu acho que isso vai acabar acontecendo, o Fábio vai ensinando para gente. Se eu tenho dificuldade e a minha esposa está perto eu pergunto para ela:- oh, você sabe como é que é este sinal? e vice versa, ela também me pergunta.

Eu acho que a gente também não pode fazer disso, dessa situação, um compromisso maçante de ter que se seguir muito a risca. Eu acho que a 
nossa vida tem que continuar normalmente o curso dela. Nós não temos que ficar aí, vinte e quatro horas preocupados, só, com o Fábio, nós temos a nossa vida e nossa vida é com a família e ele está integrado nessas vinte e quatro horas conosco e evidente que nos horários em que nós estamos com ele, fim de semana, nós procuramos manter o nosso relacionamento familiar comum. Não é porque hoje é final de semana que nós temos que ficar mais com ele, por que? Nós já estamos todos na mesma casa. Eu acho que as atividades, por exemplo, tem hora que ele quer jogar bola, tem hora que ele quer ir com a mãe no parquinho ou às vezes ele quer escrever, ou ele quer algum jogo didático ou quer assistir televisão, ou quer que a mãe acompanhe ele em alguma coisa, ou o pai, então eu procuro pelo menos levar. Não tem essa de que ai não poxa, porque realmente ele procura mais a mãe no final de semana, mas eu procuro, eu me esforço para me integrar. Mesmo quando foi tomar banho, saiu do banho, fazer mamadeira, para diminuir essa carga dela, vamos dizer assim, enfim eu procuro me integrar o máximo possível, porque ele com a mãe é mais integrado do que comigo, mas acho que isso é normal com qualquer criança.

Hoje, minhas expectativas, são de que como ele está com cinco anos e o ano que vem, mais um ano de terapia, desse acompanhamento que está sendo feito e com sete anos eu espero que ele já consiga ir para uma escola para fazer a primeira série, essa é a minha expectativa. Porque a coisa está andando um pouco mais com uma certa velocidade, por ele já estar numa escola da Prefeitura lá em Osasco. Eu diria que com sete anos ele já vai ter a 
oportunidade de fazer o primeiro ano, porque lá é uma escola oficial apesar de ser da Prefeitura, mas Prefeitura é oficial no ensino básico, até a quarta série, porque a Prefeitura não tem da quinta em diante. Mas enfim, a expectativa é que ele consiga com sete anos começar a primeira série, porque ele já sabe escrever, ele já sabe o abecedário, o nome das letras, ele já sabe fazer algumas contas, então mais um ano ainda ele já vai aprender mais algumas coisas. Ele já está um tanto quanto preparado, tanto quanto uma criança normal que vai para o pré, então isso que está acontecendo na vida dele, aqui na USP, e nessa escola da Prefeitura está sendo um pré para ele. Além da terapia de fono, óbviu, a minha expectativa é essa, que ele não perca, tempo de escolaridade como se perdia no passado. No caso da minha sobrinha e outras crianças que hoje eu conheço, algumas adolescentes que com mais de dez anos que ainda estão fazendo o primeiro ano, é essa oportunidade que eu queria para ele. Dele não perder tempo nessa parte.

Eu estou satisfeito com que está acontecendo aqui. Como em outros lugares aqui não tem muita enrolação, também não falando lá da outra escola que ele estava, da outra terapia que ele freqüentava, mas os horários são bem aproveitados. Vocês tiveram um período de greve e eu achei legal que vocês por iniciativa própria continuaram fazendo os atendimentos. Não houve interrupção, eu acho que naquele momento vocês poderiam muito bem falar que estavam sem alguns elementos aqui, que teriam que interromper. Eu achei isso aí super legal. Enfim, tudo o que a gente pede vocês estão correndo atrás atendendo, vão buscar informação para gente. Eu estou satisfeito, não vou 
falar pela minha esposa, mas de repente eu não sei o que ela vai falar e não quero que ela fale nem isso e nem aquilo, eu quero que ela fale o que ela tem que falar, eu tenho que falar por mim.

\section{Família 7 (F7)}

A) Graça - mãe da Gabriela

Meu nome é Graça e a minha data de nascimento é seis do dez de setenta e três. A minha filha se chama Gabriela, nasceu no dia vinte e dois de junho de noventa e seis e estuda em classe especial.

Eu acredito que fui eu quem descobriu que Gabriela não escutava, pois no início Gabriela nasceu bem, mas depois teve outros problemas de saúde. Foi meio complicado. Quando eu desconfiei, ela já estava com mais de um ano. Eu achei que estava demorando muito a soltar algumas palavras e pedi a pediatra. Ela falou que ainda era cedo, mas depois teve uma vez que ela teve que passar no pronto socorro e pegou um médico que teve que pedir alguns exames e ele descobriu que ela tinha surdez. Ele começou a pedir uns exames e pediu um exame para ser feito no $\mathrm{HC}$ e já deu.

Gabriela recebeu o primeiro aparelho por doação lá em Bauru e eu acho que ela tinha dois anos e pouco, e logo em seguida ela começou tratamento fonoaudiológico. A nossa sorte é que quando foi descoberto, ela terminou de fazer o outro tratamento e em seguida já começou tratamento aqui. Por isso eu falo que Gabriela é velha aqui, só que ela era tratada a tarde. 
Gabriela usa o aparelho direto. Ela só tira só na hora do banho e de dormir, mas ela usa. Porque ela ouve alguma coisa e ela usa mesmo pra ir para escola, para ficar em casa, para sair. Ela sabe quando a pilha está acabando, ela usa direto. Ela gosta dele, ela se sente bem com o aparelho. Ela gosta muito de ver televisão, de ouvir os outros falarem, então ela gosta do aparelho. E estando bom para ela, eu gosto sim, eu tenho nada contra não, acho que o bom para ela é bom para mim. O que eu estou notando agora é que ela cada vez gosta mais, porque ela mesma vai e coloca sozinha e vê o volume. Às vezes ela pede para eu olhar se está no dois ou se está no três, e eu acho interessante isso, mas ela gosta de usar.

O aparelho muda muito. Eu falo que Gabriela sem o aparelho não é nada, não é ninguém e com o aparelho ela é tudo. Porque às vezes eu estou na cozinha e ela está na sala ou no quarto e se eu falo alguma coisa com ela, ela ouve, mas às vezes se eu estiver no banheiro e eu pedir para ela pegar uma coisa sem o aparelho, ela não me atende, a não ser que eu grite, ou vá lá mais perto, mas a comunicação muda muito, quando ela está com o aparelho ajuda muito.

Eu fiquei meio em conflito porque ela recebeu o aparelho em Bauru e em Bauru era uma coisa e aqui era outra, era meio diferente. Para mim foi um conflito, vai colocar o aparelho e vai falar, vai conseguir entender, mas foi com o tempo que eu vim a entender que não é bem desse jeito. Com o aparelho ela consegue falar, mas ela não consegue entender muito bem as outras pessoas. 
As outras pessoas conversam com ela e ela não entende. E a graça é que ela conversa e agora algumas pessoa até conseguem entender, mas é meio difícil.

O que eu queria mesmo, antigamente é que ela falasse e entendesse, para ser como uma pessoa normal. A gente fala normal, como a gente mesmo, ouvinte. Para mim tinha que ser assim, depois mudou. Não é assim, é normal, mas não é assim. A gente pensa uma coisa do aparelho, mas é meio complicado. O aparelho ajuda, mas é difícil, tem que ser da maneira que tem que ser. Não é do jeito que a gente quer mesmo. Eu estou feliz agora por ela estar aprendendo sinais e eu acho que é válido isso.

A gente fala muito, mas agora a gente também está aprendendo sinais. A gente tem que aprender mais ainda. O que eu não sei, ela fala para mim, o que eu sei eu vou falando. Eu erro muito, mas ela me ensina. A nossa comunicação às vezes é por sinais. Quando ela está no ônibus ou em casa ela comunica. $E$ às vezes ela fala muito também e eu falo com ela.

Nós não criamos nenhuma estratégia para que a comunicação se estabelecesse, a gente deixou acontecer. Assim, o que é mais fácil para ela entender, se ela não consegue falar alguma coisa, ela faz sinais para mim e aí tenta falar para mim o que é e se eu acho que é mais fácil fazer os sinais para ela, eu faço o sinal, se não é eu falo. As coisas que são mais fáceis, eu falo para ela. As coisas que são mais difíceis, a gente faz sinais. Eu acho que é mais desse jeito. Eu acho que somos mais eu e ela, até o George que na 
segunda feira entrou na aula de sinais. Ele estava tentando fazer os sinais e eu achei interessante. Alguma coisa ele não consegue falar, conversar com ela, então ele está tentando da maneira dele, até aprender o sinal. Acho, que a estratégia é essa, que o que a gente sabe tentar passar ou se não, aprender mais.

As outras pessoas tentam falar porque não sabem muitos sinais. Às vezes ela começa a chamar de burro porque elas não sabem os sinais ou ela não está entendendo, porque muitas coisas que os outro falam, ela não entende.

Conversar com o pai é meio difícil porque ele não sabe nada de sinais, mas o que ele não entende, ela tenta falar para mim, para eu passar pros outro. E a mesma coisa do contrário, às vezes o que eles tentam conversar com ela, tem que chamar atenção, porque ela não está entendo o que você está falando, e eu tento passar o que eles estão falando. Então é meio assim, ela passa por mim para chegar nos outros se não, dos outros passa por mim, para chegar a ela, é meio difícil por causa disso.

Aceitar a Língua de Sinais foi meio difícil no início. Depois, acho que ano passado, que eu caí na real de que tem que aprender. Tem que aprender não, é bom aprender. Eu falei que ultimamente eu estou muito feliz, porque eu estou conseguindo aprender, já quero fazer o curso e é muito bom porque você consegue conversar com as crianças. Na escola de Gabriela eu fico boba com 
a felicidade deles tentando conversar e quando eu sei alguma coisa, eu converso com eles, é muito bom.

Quanto às reuniões de pais, eu acho que é um aprendizado. Eu acho que cada família tem uma história. Eu acho que é mais para ajudar cada um. Eu aprendi muito e eu acho que cada pessoa, com sua história, traz um pouco de força para gente. Eu acho que cheguei meio baleada e consegui estar do jeito que eu estou hoje, acho que eu devo também muito ao grupo. A gente vê muitas histórias e a gente aprende a cada dia, eu acho que é muito bom o grupo.

As coisas que acontecem no grupo eu passo para o meu marido, mas não passo tudo. Se ele pudesse vir um dia ou uma vez no mês eu acho que seria mais aproveitado porque eu tento passar o que aconteceu, a gente falou sobre isso, o que acontece eu tento passar pra ele. Não sei se ele pega, ele é meio azuretado, mas a gente tenta conversar sim, tudo o que se passa. Eu chamo um pouco a atenção dele porque ele é meio despercebido, mas eu tento passar para ele o que acontece, o que a gente conversa aqui, aí tento passar.

Desde que começamos aqui, o que mudou é que eu acho que eles estão começando entender que Gabriela é uma criança surda e que precisa realmente de sinais. Antigamente eles achavam que não, que ela iria falar, que ela não precisaria, e eu acho que eles estão aceitando um pouco mais, está 
caindo um pouco aquele negócio de Gabriela falar, vai falar, porque eles eram desse jeito. Então eles tão aceitando mais.

Hoje, eu não estou fazendo muitas expectativas. Ontem ela veio com uma história com o cobrador do ônibus, falando para ele que ela sabe mexer naquele negócio de dinheiro e que ela ia trabalhar naquilo lá. Eu achei interessante, não sei se é isso que eu quero para ela, mas vai ser uma coisa que ela vai se decidir. Porque eu falei assim, está na escola, está bem, o desenvolvimento dela está bom e para mim acho que ela só tem a melhorar. Agora minha expectativa maior é dela aprender logo a ler e escrever, eu estou esperando um pouco ansiosa, estou com um pouco de medo de demorar muito, mas acho que é devagar mesmo.

B) Gerson - pai da Gabriela

Meu nome é Gerson e a minha data de nascimento é oito do um de mil novecentos e setenta e dois. A minha filha se chama Gabriela, sua data de nascimento é vinte e dois de junho de mil novecentos e noventa e seis.

A Gabriela freqüenta uma escola que tem uma sala para pessoas especiais. Lá eles ensinam através da linguagem e através do método tradicional de ensino. Já fui em algumas reuniões e parece que é uma escola e a professora é uma pessoa que luta muito para o desenvolvimento da criança. 
A descoberta de que a Gabriela não escutava foi com o tempo. A tia e nós também, começamos a perceber, chamando. Tínhamos uma dúvida assim e fez um exame, aí constatou, eu creio que depois de uns seis meses quando a criança começa a sentir. O barulho também, que era muito alto, lá embaixo e ela dormia normalmente. A gente conversava e via que a criança não tinha aquela atenção e surgiu a dúvida, veio para cá, para o hospital, foram feitos os exames e constatou a surdez. Eu não tenho como surdez. Eu falo com dificuldade de audição, não gosto que chamem a criança de surda, não vejo dessa forma, até porque ela fala algumas palavras. E eu tenho certeza, acredito muito em Deus, e do jeito que eu acredito muito nele, eu peço para que um dia ela esteja falando. Não digo cem por cento, igual a nós, mas pelo menos oitenta por cento, noventa, ela vai estar bastante desenvolvida.

A gente começou a desconfiar de que ela não escutava quando ela estava com seis meses. Aí vem aquela fase de quando a criança começa a falar, chamar o papai, a mamãe, que é de dez meses, um ano. Quando a criança deveria começa a falar e a gente vê que a criança não está desenvolvendo, aí cria aquela ansiedade e foi a partir daí. E depois de fazer os exames, aqueles de diagnóstico mais profundo, foi daí que ele veio e falou que a Gabriela não escutava. Ela está com oito anos e isso já faz sete anos, eu creio que ela tinha entre dez meses e um ano.

O primeiro aparelho, Gabriela devia ter uns quatro anos, quando o recebeu. Não tenho a precisão do fato, estou falando que já faz bastante 
tempo, e foi por doação. E eu não me lembro quando foi que Gabriela começou tratamento fonoaudiológico.

Em casa, Gabriela usa o aparelho e até pede para que seja colocado quando ela está ouvindo desenho, alguma coisa assim. Ela pede para colocar, ela mesma já sabe. Com oito anos já sabe colocar e a gente também coloca. $E$ ela gosta do aparelho. Inclusive eu que ficava pensando, mas com o tempo, ela se adaptou e ela mesma coloca o aparelhinho dela e já pede, quando às vezes está ouvindo alguma programação, ela já pede para colocar.

Quanto a mim, todos os pais não, quer dizer, vou te falar por mim. Não quer ver o filho assim, mas claro que se é uma melhoria para ela, eu fico feliz. Fico feliz por ela estar a cada dia desenvolvendo mais, a cada dia ela fala uma palavra a mais, a cada dia procura mais. Ela gosta muito mesmo é de escrever, me chama para fazer simulação de escolinha. Passa atividade e ela fica falando, ensina o "A" e o "É" e ela fala ba, começa com as famílias, coisas de Deus, coisas que deixam muito gratificante.

O jeito de eu falar com ela é o mesmo, ela estando com ou sem aparelho, mas a maioria do tempo ela está com aparelho, a não ser, é claro, quando a gente tira, mas a maior parte do tempo ela está com aparelho.

Quando entramos aqui na USP, eu esperava o que está acontecendo. Que com o tempo, ela fosse desenvolvendo a cada dia. Eu sei que não é um 
processo rápido, é uma coisa de tempo, mas é isso mesmo que eu esperava. É claro que como pai, a gente está sempre esperando alguma coisa, eu mesmo como eu te falei, acredito muito em Deus e eu creio que ela já é um milagre de Deus, pelas dificuldades que teve após o nascimento e a internação. Eu vi Deus agir na vida dela, junto com nossa mãe, que eu acredito muito na Virgem Maria e daí o nome dela, eu creio que eles estão por perto ajudando a cada momento e eu creio na superação cada vez mais, mas o que eu esperava era isso mesmo, que ela se desenvolvesse. Ela fala papai, ela fala muitas coisas gesticulando, mas são muitas as palavras que ela fala que são claras, a gente entende perfeitamente, e tem como a gente dialogar com ela.

A língua minha que eu falo com ela é normal. Algumas coisas com o jeito que ela tem, ela fala, mas também tem o jeito da gente falar, mas lá ela fala com gesto e comunicação normal, assim, ela entende algumas coisas. Agora numa historinha que a gente vai contar, tem que contar e fazer daquele jeito, com um jeito especial, gesto, falando o tamanho, tal, essas coisas.

A estratégia que existe é vendo o que ela entende melhor, o gesto, as coisas. Como eu te falei, os gestos, o jeito, mas eu considero que ela entende muito a nossa linguagem. Ela é uma criança muito esperta, graças a Deus, muito inteligente. E cada dia que passa ela desenvolve mais uma coisa, vai desenvolvendo e eu creio na superação total rapidamente. 
As outras pessoas se comunicam com ela normalmente como eu com ela. Eu tento deixar os dois na mesma coisa, até quando eu vou falar alguma coisa, repreender alguma coisa, do mesmo jeito que eu falo com um, eu falo com o outro. Não faço essa separação. Agora, ela fala mais próximo dela e eu vejo que ela repete as palavras algumas vezes, ela tem esse jeito de falar com ela, um jeito assim um pouco diferenciado, mas ela procura sempre falar com um, falar com o outro sem mudar muito a forma.

Quanto à Língua de Sinais, eu vou falar sinceramente. No começo eu queria que ela desenvolvesse, a gente nota nela, estava desenvolvendo, estava não, está desenvolvendo, e ela numa superação. E eu falei não para que Língua de Sinais? Mas aí com o passar do tempo, a mãe foi falando e eu também nunca vou falar que não vou aceitar alguma coisa. Sempre o que for melhor para ela eu estou junto, e para ela foi melhor porque aí ela faz a Língua de Sinais e fala e foi isso o que aconteceu, graças a Deus. Ela gesticula, faz as letras e vai escrevendo os nomes e vai falando. Melhorou nos dois sentidos porque ela faz os gestos e também a comunicação melhorou.

As reuniões do grupo de pais, eu avalio de uma maneira importante. É muito bom estarmos conversando como hoje aqui. Expor, conversar e assim, um vai ajudando o outro, vai dando idéia, vai comunicando, vai se entendendo. É muito importante a amizade aqui. A vida está muito corrida e quando a gente se encontra para discutir, para tentar encontrar uma solução para alguma coisa ou ajudar de alguma forma, eu acho importante. Eu mesmo gosto bastante de 
participar quando eu posso. Como eu te falei, um encontro, um passeio, eu gosto de estar junto sentindo o clima ali, as crianças todas juntas.

Em casa a Graça fala sim das coisas do grupo, ela conversa comigo sempre, todas as coisas que acontecem. Da dinâmica em casa mudou apenas que agora ela vem aqui e já vai com aquilo para gente discutir em casa e o que o que ela aprende a linguagem, ela conversa com a gente. Até a Gabriela me ensina, mas nosso modo de viver é sempre em Deus, sempre naquela família tentando o máximo evitar discussões, essas coisas para que a criança não se envolva naquilo e graças a Deus, minha família foi sempre feita por Jesus Cristo. A gente procura viver assim, e nossa convivência não mudou. Mudou o desenvolvimento dela. Ela tenta nos ajudar, me ensinado alguma coisa, ensinando a mãe, a mãe também, nas reuniões aprendendo algo a mais para acrescentar no dia a dia lá em casa.

Hoje ela está com oito anos e eu vejo, eu sou sempre otimista, eu creio que ela daqui a pouco estará lendo. Ela está começando a falar as palavras e minha expectativa é a melhor possível. Vou te falar porque, até como pai, a gente não pode nunca desanimar, eu não desanimo nunca. Minha expectativa é vê-la estudando em uma escola normal, lutando, fazendo uma faculdade, que meu pai queria me dar e não pode. Mas eu vou tentar fazer o máximo por ela e pelos dois. Dar aquilo que meus pais sempre quiseram me ajudar, mas que pelas dificuldades, por ter vindo da roça, do interior, não conseguiram e eu quero dar para eles o melhor. Quero vê-la uma pessoa 
normal, fazendo o que ela gosta, procurando sempre incentivar, sempre impondo os limites, porque também a gente tem que dar e saber cobrar responsabilidade da criança. Eu quero sempre o melhor para eles e como eu te falei, o outro é normal e eu trato os dois igualmente, tenho certeza que ela vai se desenvolver e vai falar como nós.

Eu agradeço a Deus por vocês, pela professora dela na escola e por Ele ter ajudado a gente. Ele nos dá força, nos dá coragem para trabalhar. $\mathrm{O}$ desenvolvimento dela a cada dia melhora mais e eu agradeço muito a Deus por isso. Em vez de ficar lamentando o acontecido, é uma luta, é arregaçar as mangas e partir para luta e eu tenho certeza que a gente vai alcançar nossos objetivos, menos lamentações, agradecer mais a Deus o dia e a saúde que ela tem e esperar sempre o melhor, esperar sempre em Deus e esperar sempre o melhor pra nós.

\section{Família 8 (F8)}

A) Horácio - pai da Helena

Meu nome é Horácio, e nasci em vinte e três de Junho de mil novecentos e cinqüenta e nove. $\mathrm{O}$ nome da minha filha é Helena, nasceu em sete de maio de mil novecentos e noventa e um e estuda em uma classe especial só de crianças surdas, de uma escola comum.

A minha vizinha foi a primeira a perceber que a Helena não escutava quando ela era novinha, seis, sete, oito meses... A nossa vizinha, uma 
mocinha, que sempre vivia com ela, brincando com ela. Ela percebeu e falou pra Helga que a menina não ouve não! Foi quando observamos melhor. Mas pelo menos foi a vizinha, a mocinha que ficava com ela sempre lá em casa brincando.

A surdez dela foi diagnosticada a partir dos primeiros exames, e ela já tinha um ano e algumas coisas, mas recebeu o primeiro aparelho, por doação, quando ela já tinha uns três anos, porque até fazer os exames, foi aquela demora e esperar fazer o pedido de aparelho e esperar chegar foram uns três anos.

Em casa a Helena tira o aparelho só para dormir e tomar banho, ela nunca desgruda dele. Ela gosta do aparelho, gosta bastante. Quando ela levanta da cama, depois que escova os dentes, banha o rosto, já vai direto buscar o aparelho, não precisa ninguém mandar. $E$ ela mesma cuida do aparelho, ela mesma troca as pilhas. Ela percebe quando ele está fraquinho, ela já pede, e ela mesmo troca.

Quando ela está de aparelho a nossa comunicação muda um pouquinho pois com o aparelho ela, ela ouve e sem o aparelho, ela não percebe que a gente está conversando com ela, muda um pouquinho, com o aparelho é melhor. 
Para que a Helena começasse um tratamento fonoaudiológico, eu acho que demorou um pouquinho. Ela foi para escola com uns três anos e pouco, lá nesse mesmo lugar que ela estuda, mas aí eu acho que ela não freqüentava muito esse tipo de coisa que você está falando, depois quando ela tinha uns cinco anos, a gente mudou para Carapicuíba e na escola tinha e então foi quando ela começou a freqüentar, na COHAB, na escola.

A gente quis vir aqui para USP, porque aqui era uma coisa mais certa. Nas outras em que ela passava, a gente achava que era uma coisa que não tinha muito prosseguimento, era muito menos agradável e aqui a gente tinha mais esperança de que as coisas fossem melhores, o atendimento mesmo das fonos, Porque lá, a gente achava que não tinha muito futuro, as fonos não atendiam muito legal. Aqui é com certeza, bem melhor.

Nós conversamos como se fosse entre duas pessoas normais. Eu não procuro conversar com ela assim, em língua de sinais, só algumas coisas que ela não entende eu procuro (fazer o sinal) e então a gente consegue se entender. Mas normalmente é só falando, aí quando é em língua de sinais e eu não consigo entender, ela já fala logo que está errado e ela já corrige que está errado. Às vezes a gente conversa em casa e ela não ouve, não entende direito, aí eu procuro fazer com que ela me entenda, eu apresento a coisa, por exemplo, que eu estou procurando informar para ela, e eu falo:_Tá vendo como é que é? E então ela lembra, e é assim. 
Quanto à Língua de Sinais no início a gente acha um pouquinho estranho, mas que é importante é. É muito bom! Porque é mesmo, até para o meu tipo de trabalho. A gente recebe muitos passageiros, muitas pessoas que têm esse tipo de problema e a língua de sinais ajuda até no serviço. E eu consigo conversar com algumas pessoas. Mas só com alguns, pois é um serviço que a gente não pode descuidar muito, mas isso é bom.

As reuniões do grupo de pais são legais porque um esclarece uma coisa, outro esclarece outra e esse é um tipo de coisa que se não conversar, ou não estudar, não vai aprender nunca. Os informes são bons! Eu tenho aprendido muito, mas contribuído, talvez não o bastante, mas alguma coisa ajuda, é importante.

Desde que começamos aqui, nossa comunicação melhorou, até junto, em casa, com os irmãos, eles entendem melhor também. O jeito dela falar e de comunicar tudo, os irmão entendem melhor. E ela só conversa falando mesmo em casa. O negócio de Língua de Sinais em casa não usa não. Ela só usa isso em casa quando ela recebe uma coleguinha, aí ela só se comunica na Língua de Sinais, mas só o pessoal de casa, com o vizinho é só falando, ela fala tudo, a prima, a tia, a avó.

Às vezes eu fico pensando, será que ela vai crescer, vai poder trabalhar amanhã ou depois... A gente fica na dúvida, mas a esperança é isso. Ela fala que vai trabalhar quando crescer. Que vai trabalhar, ganhar dinheiro e 
comprar um carro (fez sinal de comprar carro). É ela fala bastante isso, vamos esperar.

Às vezes eu fico pensando assim, que ela já deveria estar aprendendo a ir para escola sozinha, mas a minha mulher tem medo. A Helga tem medo de deixar, mas se nunca deixar, ela nunca vai se desenvolver, não se todo mundo ficar levando e trazendo. Porque atravessar a rua, ela sabe tudo direitinho. Às vezes eu vou com ela, ela vai na frente, eu me atraso um pouquinho e ela atravessa a rua, espera legal. E ela sabe o ônibus também, conhece todo mundo. Ela é meio tímida para conversar com os motoristas que são todos colegas meu e às vezes ela gosta de um, às vezes não gosta e diz: - ah, esse não, vamos no outro. Porque ela percebe que o outro é mais legal, mas é preciso deixá-la senão não costuma e não perde o medo. Não é perigoso lá no setor da escola, atrás do Pão de Açúcar, é uma rua que só mora gente um pouquinho de alto nível e tem segurança na rua, aqueles rapazes lá, não são perigosos, não é escola com aqueles caras fumando em praça que não tem o que fazer, não tem isso lá, é legal.

B) Helga - mãe da Helena

Meu nome é Helga e nasci em trinta e um de julho de sessenta e um. Minha filha é a Helena sua a data de nascimento dela é sete de maio de noventa e um e ela estuda em uma classe especial só de crianças surdas, de uma escola comum. 
A primeira pessoa a perceber que a Helena não escutava foi a minha vizinha, ela disse que chamava e ela não escutava e então ela falou para mim, depois fez os exames e acusou. Nessa época ela ia fazer dois anos, e começou a usar aparelho com três anos e meio, e não demorou para ela receber o aparelho, foi rapidinho... Acho que em antes de um ano entre o exame e a doação do aparelho.

A Helena usa o aparelho em casa e a relação dela com o aparelho é normal, ela não reclama e gosta dele. Ela coloca sozinha, ela troca a pilha sozinha também. Eu a ensinei a trocar porque ela não vai me ter a vida toda e então ensinei ela trocar. E ela usa o aparelho o dia todo. Ela só tira quando vai tomar banho, depois se seca e coloca de novo, vai para escola e tira de noite quando vai dormir.

Quando a Helena está de aparelho, ela escuta, agora quando ela não está ela não escuta não e aí muda o jeito d'eu falar com ela porque ela não escuta. Eu falo e ela não escuta. Aí eu vou lá, eu toco nela. Aí ela escuta e com o aparelho, eu chamo assim e ela escuta normal. Eu falo normal com ela. Não falo por gestos e eu falo e às vezes ela entende. Agora tem coisas que ela não entende, aí ela faz gestos, às vezes eu entendo também, às vezes não entendo, aí quando não entendo, fica por isso mesmo.

Eu não tenho muito tempo para ficar com ela, o meu tempo é muito pouco, mas só que às vezes eu fico. Só que é muito pouco. 
Quanto ao atendimento fonoaudiológico eu não lembro quando ela começou não, mas ela passou um tempo na Lapa, só que não era que nem aqui. Era normal, a fono normal. Não era que nem aqui, era diferente. Acho que ela passou lá uns três anos, não, foram quatro anos lá. Depois foi no tempo que mudei para Carapicuíba, depois vim para cá há uns três anos. Me disseram que a pessoa tinha de marcar pra fazer a triagem, então eu marquei e aí continuei. Eu queria que ela fosse atendida aqui e que ela ficasse aqui fazendo fono porque aqui era muito bom.

A Língua de Sinais, a gente tem que aceitar. Por mim eu não aceitava, mas fazer o que? Tem que aceitar. Eu acho que ela se beneficia com isso. Quando ela conversa com os outros ela conversa falando e quando a pessoa não entende, ela faz sinais, mas as pessoas também não entendem o sinal que ela faz. Só os conhecidos mesmo ela entende. A menina, a irmãzinha dela às vezes vai falar com ela e faz sinais. A pequenininha faz sinais para ela entender e às vezes faz sinal para irmãzinha dela e ela entende também. Só que é mais normal. Com os outros irmãos, ela conversa normal. Agora com o pai dela, às vezes ele conversa por gestos com ela, mas aí é normal também. E ela gosta dele pra caramba. Ela não gosta que eu venha com ela. Acho que ela prefere ele do que eu. Porque para vir para cá, se eu venho com ela, a gente vem de ônibus, e se é o pai, ele vêm de carro e ela não gosta de andar muito a pé. 
Eu não venho muito, assim direto, nas reuniões do grupo de pais, mas eu acho que é bom. Eu não venho muito porque acaba muito o meu tempo. Porque eu chego em casa e é a maior correria para fazer tudo, comida, ir para escola e dar conta da casa também, então eu boto mais o meu marido para vir. Mas eu gosto. Quando eu venho eu acho bom, só que quando chego em casa a correria é grande.

Em casa não mudou nada desde que a Helena começou tratamento aqui, tudo continua a mesma coisa. Mas eu espero que coisas boas aconteçam, que ela se desenvolva mais, aprenda a falar.

\section{Família 9 (F9)}

A) Inês - mãe da lara

Meu nome é Inês e nasci no dia onze do quatro de setenta e sete. $\mathrm{O}$ nome da minha filha é lara, nasceu em treze de agosto de dois mil e um. Tem três anos e ela estuda no Rotary que é escola especial para surdos.

Quem primeiro percebeu que a lara não escutava, juntando estávamos eu e meu irmão. Primeiro ele começou a desconfiar, depois a gente, juntos. Ele brincando falou para mim que a lara não ouve, porque ele começou a chamar ela. Aí começamos ver, observar, e sempre que chamava por trás, ela não ouvia. A gente chegou até a pensar que ela não se importava porque era pequenininha, mas depois a gente foi fundo, se informou com outras pessoas e com a ajuda de profissionais a gente conseguiu otorrino e deu no exame que 
ela era surda. Nessa época ela tinha meses, de sete para oito meses, ela estava começando a engatinhar. A gente chamava enquanto ela estava engatinhando e ela ia embora. A descoberta para mim foi assim, eu fiquei tranqüila, vi como uma coisa normal que Deus mandou para mim, que eu tenho que cuidar e só isso.

No dia que eu vim fazer o exame aqui na USP, eu não lembro bem a data, sei que foi mais ou menos no mês de Abril, Fevereiro, no começo do ano, e ela estava com dois anos por aí. Foi em 2003 quando eu recebi o exame que a moça falou para mim e explicou para mim tudo direitinho. Fiquei meio assim, sem entender direito, mas depois eu só sabia que ela nasceu surda, que não ouvia e que eu tinha que fazer aula de sinais, que ia ser uma andada para que ela se desenvolva bem, para que no dia que eu não estiver mais perto dela, ela estar preparada para o mundo.

No começo do ano também, eu fui encaminhada daqui da USP para o hospital São Paulo. Eu fiz a entrevista com eles e coisa de dois, três meses ela já ganhou os aparelhos por doação do hospital, porque eles dão prioridade para as crianças pequenas.

A partir do exame, assim que a gente fez o exame, ela começou a fazer a fono também, aqui na USP. 
A lara usa o aparelho em casa. Ela gosta dele, só que às vezes quando ela quer falar, ela pega o celular e tira o aparelho para falar no celular e quando está calor e ela começa a coçar, acho que esquenta, ela tira, mas fora isso, ela deixa tranqüilo. Eu gosto do aparelho, apesar de que ela ainda não solta muito o som, não mostra muito, coisa mínima, mas já é alguma coisa. $\mathrm{O}$ pouquinho que ela já mostra, um barulho. Ela já está bem desenvolvida, de uns dias desses para cá eu estou vendo mais, então está começando mesmo de agora.

Eu falo com sinais e falo também com a boca. Eu ainda não consigo falar em uma língua só, faço as duas juntas, então a comunicação é a mesma quando ela está com e sem aparelho.

Quando viemos para cá queria só ter certeza, porque a gente tinha aquela suspeita, mas a gente fica meio assim, não acredita muito. Aí quando a gente fez o exame, eu tive a certeza e ficou detectado de vez. Ela é surda, está assinado. Do tratamento, o que eu esperava era primeiro os sinais porque já veio para mim que os sinais é a língua natural deles. Não existe outra, se eles buscam outro é uma coisa natural. Graças que tudo o que eu esperava é o que está acontecendo, é o que vem acontecendo porque ela faz sinais, faz fono. Como ela brinca com as coisas, eu aprendi muito também com as fonos. Elas sempre estão orientando e a comunicação dela é uma coisa também que é linda. 
Eu sempre procuro chamar a atenção dela olhando para mim porque a gente está falando e ela olha para cá. Eu a chamo, mando ela olhar para mim e falo. Eu estou falando sinal e falando também. E eu vou seguindo conforme a gente vai aprendendo com a Língua de Sinais e vai agindo assim naturalmente.

O pai por ele não ter muito contato que nem eu que saio sempre com ela, ele está aprendendo no dia a dia comigo em casa, com ela mesma, porque ela já pega na mão dele e ensina a fazer os sinais. O Ivan faz sinais, não muito bem, mas ele inventa, com a mãozinha dele dura, mas ele já está bem.

A Língua de Sinais, eu aceitei desde o momento em que o exame constatou que ela era surda, que vieram explicar para mim que ia ter que fazer aula de sinais. Aí conheci a professora surda, eu nunca tinha tido contato com surdos. A minha visão lá fora era bem diferente, difícil e eu achava bonito, sempre admirei. Eu já peguei de cheio e eu admiro, cada dia mais quero aprender, busco sempre e o que eu quero é aprender mais e mais.

As reuniões do grupo de pais são muito boas, porque às vezes a gente acorda, por exemplo, a gente sai vai para o atendimento dela e tem uma dificuldade no atendimento, você não é atendido do jeito que você esperava, aí você vem cheia e você escuta uma mãe ou um pai falando do que passou, foi a um tal lugar e passou tal dificuldade, e você vai ouvindo, vai fortalecendo porque não é só a gente, só eu, que tem outra mãe que passa também e ela mostra ali uma tranqüilidade que você passou. E você pega aquilo para na 
próxima reagir melhor do que reagiu no começo, mesmo sofrendo, porque é dolorido quando a gente vai é a maior dificuldade quando a gente busca alguma coisa, você vê uma dificuldade enorme.

Às vezes eu converso em casa sobre as coisas que aconteceram no grupo. Eu passo um pouco para o meu marido, mas ele é muito desligado, está de frente para a televisão, e eu estou falando. Ele não está olhando e eu já fico nervosa: -Tô falando com ninguém, deixo prá falar depois quando quiser me ouvir! Fico nervosa mesmo, aí fico quieta, me encho de raiva e eu não falo.

O que mudou desde que começamos aqui foi o jeito da gente se comunicar. Eles vêem mais pelo conhecimento que eles têm, eles não vêem assim como uma coisa normal. Ela só é surda, mas é uma pessoa que pode viver naturalmente. Eles vêem mais com pena, coitadinho. Antes eu ficava muito triste porque eu não vejo assim. Eu queria que eles vissem como eu via também, do meu jeito, mas agora eu entendo que eles não têm conhecimento. Se eles viessem, se um deles viesse duas vezes ou três vezes no grupo de pais, ou fosse na aula de sinais com o professor surdo da escola, eles iam ver totalmente diferente. Eu vejo que por eles não terem esse conhecimento, eles vêem como pena, com dó, coitadinho, é surdo, não fala e não é nada disso.

Hoje eu espero que continue como sempre. Que graças a Deus sempre fui bem atendida aqui. Quando ela começou a aprender a língua dela, a brincar, como brincar, o que eu peço e agradeço sempre é que foi desde aqui 
que a gente começou, e continua aprendendo. E eu quero que continue. Eu só tenho a agradecer, agradecer, agradecer sempre, sempre.

B) Igor - pai da lara

Meu nome é Igor e minha data de nascimento é vinte e nove do seis de sessenta e nove. Minha filha se chama lara e a data de nascimento dela é dezenove de julho de dois mil e ela freqüenta a escolinha do Rotary, escola especial.

Quem primeiro percebeu que a lara não escutava não dá nem para dizer porque uma hora eu conversava com ela e ela não percebia, depois a mãe. A gente mexia com ela, falava e ela nem percebia. Só percebia quando ela sentia alguma coisa mexendo nela e percebia que tinha alguém ali, mas no chegar, a gente chegava e do jeito que ela estava ali brincando, não ligava.

A gente começou a desconfiar quando ela tinha de seis meses a sete meses. E essa descoberta foi fácil. Foi fácil e não foi porque você ganha uma criança ali deitada, você fala com ela, grita com ela, grita assim, modo de chamar alto e ela não percebe que você está falando com ela. Aí a gente começou a falar por trás dela, colocar ela assim no lugar e falar, falar e ela não percebia. Foi quando a gente tomou essa atitude de procurar saber, os exames, porque antes a gente começou a desconfiar, mas levamos no médico umas quatro ou cinco vezes e o médico falava que aquilo ali era normal. Fazia exame e falava que era normal, que ela ia começar a ouvir, mas acho que o 
médico foi errado. $\mathrm{E}$ a gente só teve o diagnóstico mais ou menos um ano depois disso aí. Porque ela tinha problema no pezinho, tinha problema de sopro no coração e aí foi fazendo os exame todos juntos. Um primeiro para depois o outro e foi quando descobriu que ela tinha só audição profunda.

O primeiro aparelho dela, ela recebeu por doação, mas eu não lembro quando foi, não. Agora tratamento fonoaudiológico já tem uns dois anos que ela faz.

A lara usa o aparelho dela em casa. Sempre quando eu estou e a mãe está ela usa porque a gente trabalha, passa o dia mais fora do que mesmo em casa. A mãe trabalha um dia sim o outro não, então o dia que ela não está trabalhando ela está vindo para cá. Ela não reclama do aparelho não. A gente sempre coloca. Às vezes ela pede para colocar e ela tira só quando ela passa o dia inteiro com ele. Chega e quer pegar o telefone, quer ligar e aí ela já arranca.

Mesmo quando ela está sem o aparelho, a minha comunicação com ela não muda. Sempre eu tento me comunicar com ela do jeito que ela me entende. Eu a entendo e ela me entende e aí é uma conversa diferente. Agora, eu gosto quando ela está de aparelho porque se for para melhorar o comportamento dela ou a conversa com as pessoas, é até bom para ela, tanto para ela como para mim, pois eu vou poder conversar melhor com ela e 
entender melhor. Porque para gente entender esse pequenininho, para quem nunca viu, nunca conversou com uma criança dessa, é uma conversa nova.

Quando a gente veio procurar atendimento aqui a gente esperava que fosse tudo bom que nem está sendo, bom para ela, ela poder aprender o sinal dela, tanto para ela como para se comunicar com os outros, e passar para gente porque a gente aprende não é com os outros é com ela mesmo dentro de casa, são eles que vão ensinando para gente.

Eu falo daquele modo de falar, mas eu falo usando sinal. Ela também, ela fala mas usando sinal dela. Eu também procuro falar de frente para ela, para ela ver meus lábios batendo e fazendo sinal. Eu estou aprendendo com ela, pelo que ela está levando daqui. Sou eu que estou aprendendo com ela, quando ela faz um gesto novo, um sinal novo eu já vou entender o que é e ela explica para gente o que ela quer e o que ela não quer. Eu vou aprendendo com aquilo ali. Eu não tenho como usar uma estratégia nova para falar com ela, eu estou aprendendo com ela, tanto com ela, como aqui dentro. Você não sabe uma coisa e você está aprendendo com aquilo ali que você está vendo. Os outros em casa, conversam com ela falando também e usando sinal.

Em relação à Língua de Sinais, a gente nesse mundo tem que aceitar tudo. Independente do que seja, esse problema não é do outro mundo, é normal porque ela não é a primeira que nasceu desse jeito. Eu já vi muitos 
assim, mas só que eu nunca tive a oportunidade de falar em sinais com eles, então a gente tem que aceitar do jeito que vier.

As reuniões do grupo de pais são muito boas. Pelo menos a pessoa já fica sabendo de mais coisas e aprende mais convivendo com essas reuniões. Vendo o que vocês passam para gente é até bom, porque a gente em casa vai procurar conviver melhor com a criança.

E a lara passa pra mim as coisas do grupo. Tem a casa cheia de papel que ela enche lá e manda eu ir estudando para aprender a letra e o sinal. Ela sempre está me pondo na parede para isso, ela é brava. Eu chego meio cansado, tem hora que eu falo para dar licença, que não tenho tempo não, para deixar eu dormir. Mas ela diz que depois eu tenho que prestar atenção na letra e eu digo que o dia que eu chegar mais cedo, e tiver mais uma folgazinha. Porque tem esse trabalho mesmo, tem final de semana, tem mês, dois meses que às vezes eu não passo nem o final de semana em casa, só trabalhando é sábado, domingo, segunda e assim vai. Tem um mês que eu passei o mês inteiro fora, trabalhando sábado e domingo e cheguei esses dias. Aí chego sete, oito horas, nove horas, dez horas, onze da noite, chego e caio na cama, aí não tem como.

Depois que começamos o tratamento aqui USP, mudou algumas coisas na nossa família, porque antes eu mesmo era um que estava preocupado quando descobri que a minha filha não ouvia, nem falava. Eu 
mesmo me preocupava assim. Ficava pensando como é que ia ser. O convívio entre eu e ela e como é que ia ser a vida dela para frente. Porque uma pessoa que não fala e que não ouve, ela não pode andar sozinha por aí. Como é que as pessoas vão entender se ela quiser alguma coisa, ou comprar alguma coisa, como é que uma pessoa vai entendê-la? Não tem como, aí eu ficava meio desanimado. Foi quando a gente conseguiu aqui, e foi mudando, os primeiro sinaizinhos dela que eu vi, no caso, e a mãe explicando e ela também, me deixou feliz, porque eu sei que ela é mais inteligente que qualquer um de nós, quer dizer que qualquer um d'eu. Porque inteligente ela é mesmo. Eu fiquei feliz e eu estou feliz com isso.

Hoje eu espero que se veio até aqui, e ela está melhorando cem por cento, eu espero que continue assim. Sempre melhorando cada vez mais, tanto do lado dela quanto do nosso.Se a gente aprender a se comunicar com ela direitinho dentro de casa, vai ser bom de mais.

\section{Família $10($ F10)}

A) Julia - mãe do Jorge

Meu nome é Julia e sou mãe do Jorge. O Jorge estuda em uma escola especial pra surdos da Prefeitura, uma escola especial para surdos.

Fui eu quem primeiro percebeu que o Jorge não escutava e foi no aniversário dele de um ano. A gente começou a perceber um pouco antes, mas no aniversário, por causa das bexigas, do barulho, eu fui percebendo que ele 
não acordava com barulho, que ele não tinha reação nenhuma a barulho, então eu comecei a perceber que tinha alguma coisa errada, mas foi só depois de um ano que a surdez foi realmente diagnosticada, lá na Santa Casa. Quando ele tinha quase dois anos

Eu achei que ele era surdo, achei que ele tinha algum problema, mas eu achava que era devido à infecção que ele teve, porque ele teve uma otite que vazou. Teve febre alta, tomou remédio, então falei que tinha alguma coisa. Meu primo trabalha lá (na Santa Casa), e ele conseguiu uma consulta, foi nessa época.

Faz três anos que ele recebeu o primeiro aparelho, ele tinha três anos. E entre o diagnóstico e ele receber o aparelho levou um ano, porque eu ainda estava na Santa Casa. E nós é que compramos, com ajuda de pessoas compramos o aparelho.

Normalmente o Jorge usa aparelho em casa. Ele não está usando agora porque está com problema, mas ele usa, desde a hora que acorda, como óculos que a gente coloca assim. Só que agora está sem usar.

O Jorge gosta do aparelho. Ele só quer tirar quando está suando, quando ele sente que está incomodando, aí ele tira sozinho, mas é só assim, no geral ele usa. Ele usa $70 \%$ do dia, porque não é imediato, ele acorda e já coloca. Tem aquele tempo, mas eu faço ele entender que tem que usar. Ele vai 
para escola a tarde e quando chega em casa, ele tira. Ele tira porque está suando, às vezes já vem na caixinha na perua, é assim que ele faz.

A nossa comunicação é diferente quando ele está com ou sem aparelho. Ela muda porque ele localiza os barulhos e aí ele tem mais atenção. Ele percebe o som e ele fala, mas ele usa, gosta dos sinais e gosta de falar da maneira dele.

Ele começou tratamento fonoaudiológico na Santa Casa, não lembro a data, mas foi na Santa casa. Foi em 2000.

Quando a gente entrou aqui, eu queria que ele falasse! Era isso o que eu achava no começo, eu achava que aqui iam curar o ouvido dele. Inocentemente eu achava que ia chegar e descobrir o problema do ouvido, que ia ter cirurgia, que ele ia falar. Depois eu vi que não era isso, mas no princípio era isso. Eu achava que eu ia conseguir, que ele ia operar, que ia ser cera no ouvido, mas depois a gente viu que não era.

Quando ele quer comunicar e ele não sabe, ele mostra, mas ele usa muitos sinais e ele fala, da maneira dele, ele fala. A gente não entende, mas ele vai falando junto com os sinais. Ele conversa com a gente. Ele acha que a gente está entendendo o que ele está falando, mas é mais por sinais, a gente se entende muito por sinais. Ele é muito rápido. Se você tiver que usar as duas mãos para fazer sinais e usa uma porque a outra está ocupada, ele entende. 
Se você falar carne, se você fizer assim (o sinal de carne com uma mão só) e falar, ele entende que o que você está falando é carne, então ele é rápido nisso, com uma mão só ele entende então ele gosta mais dos sinais, mas ele fala da maneira dele.

A gente não tem nenhuma estratégia, acho que é do dia a dia, é de olhar para ele. Ele entende muito de olhar para ele. É como estou falando, se ele vê, ele pergunta o que eu estou fazendo, da maneira dele com sinais. Então se ele quer falar carne e ele não sabe, sai da maneira dele, sai o sinal certinho, mas ele entendeu, então a gente estabeleceu assim, de olhar um para o outro, tudo ele mostra, tudo ele escreve, tudo ele desenha.

Aceitar os sinais para mim foi normal, foi muito bom. No começo eu não entendia, mas foi a parte mais importante porque hoje eu vejo como são importantes os sinais, porque tudo em casa é por sinais, tudo. Ele fala, mas a gente não entende, então não adianta, a gente mantém uma comunicação falando porque a gente sabe o que ele quer falar, mas é por sinais. Foi importante por causa disso, porque tudo é sinal, tudo.

As reuniões do grupo aqui são importantíssimas. Para mim como mãe é super importante porque ali é onde a gente coloca as dificuldades e a gente vê as dificuldades dos outros, então a gente fala: -não é tudo isso que a gente pensa. É a troca de informações e a assistência porque a gente consegue sair daqui muito bem. $\mathrm{Na} 4^{\mathrm{a}}$ feira a gente sai assim. Tudo aquilo da semana que a 
gente guarda, você sai leve daqui porque você vê que não é tudo isso então é bem mais fácil.

Depois que entramos aqui mudou tudo. Mudou a visão que a gente tem em relação aos outros surdos. Em relação até preconceito mesmo, porque eu via o preconceito das pessoas em relação ao meu filho surdo achando que ele era um doente mental. Às vezes ele grita, a gente aprendeu a lidar com isso, vendo que as outras crianças também têm o mesmo tipo de problema, então para gente como família, mudou nisso. É importante a gente ter esse grupo, porque é uma terapia para mim. Essa postura que o grupo tem é legal, a gente sai daqui numa boa mesmo.

Hoje o que eu espero é que ele fale, mas não daquela maneira forçada, e que ele seja um menino normal. Que ele possa pegar um ônibus sozinho, que ele possa vir no grupo, assim adulto mesmo, sabendo das coisas. Hoje minha expectativa é essa, que ele progrida, que ele fale, que ele fique bem nos sinais mesmo, e que acabe esse preconceito, porque às vezes até ele mesmo tem vergonha dependendo da atitude que ele toma. Então eu falo que ele é surdo, aí ele acalma, então ele já está entendendo, tendo essa consciência. E um ajuda o outro, então a minha expectativa é essa, que ele progrida, não sei se ele vai falar bem ou não, mas que nos sinais ele já está bom, ele está. 
Em casa eu converso tudo com o José. Quando eu não venho, eu pergunto tudo e ele também é a mesma coisa e a gente também discute sobre tudo, a gente discute também sobre os problemas, porque às vezes ele está assim porque sou eu que estou errada. Às vezes eu também não estou com paciência, mas aí eu tenho que parar, e é a mesma coisa o Jorge. O Jorge é muito assim, se você não olha para ele, ele fica assim, (pedindo para olhar para ele). Não adianta você mentir para ele, ele quer falar alguma coisa, quer expor o que está acontecendo, você tem que ficar olhando para ele, porque ele fala: -olha para mim. Interagiu tudo mesmo, a gente discute muito sobre tudo aqui.

Eu espero que o grupo continue assim, não vejo que está faltando nada. Para mim está bom, acho que diminuiu o horário e isso daí acho que prejudicou um pouco porque a gente não consegue concluir tudo. Fala-se bastante, tudo, mas não consegue terminar. Às vezes você vem com uma idéia, você chega aqui, e você não consegue colocar tudo, quando você vai embora pensa que devia ter falado aquilo. É só isso, mas do resto, acho que está bom, porque a gente vai discutindo o problema. Eu acho que tem que continuar.

A única contribuição que eu posso falar, é que eu falo demais e eu gosto de falar das minhas coisas mesmo. Eu acho que tem gente que não fala muito, então a gente acaba não sabendo muito. É do pouquinho só que a gente leva, então talvez seja por causa do horário, mas acho que tem que ter mais 
participação de todo mundo ali, não precisa falar intimidade, mas eu acho que está faltando isso. A minha contribuição é essa, eu falar, ajudar, não sei de que maneira eu posso ajudar mais, mas é falar do meu filho e da minha casa. Eu contribuo assim, falando que eu leio muito, que a minha casa é uma bagunça, mas é uma bagunça assim, tem livro para tudo quanto é lado, é brinquedo para tudo quanto é lado, lá tem lápis de cor, tem massinha, é uma escola mesmo. Então quando ele chega e ele fica com vontade, tem mesinha, tem tudo lá. Eu procuro colocar na televisão, fita, o que eu posso. A minha contribuição para o grupo é essa, é mostrar que é importante o livro, historinhas, às vezes eu não sei, eu invento.

Todo mundo em casa se comunica por sinais e falando, é tudo. A Josi já sabe, o João já sabe, o José tem mais dificuldade porque ele não fica tanto. Fica, mas não fica tanto, mas ele se comunica também muito bem, e o que ele não sabe o Jorge ensina, porque o Jorge já sabe que ele está fazendo errado e ele entende o que o pai está querendo falar. Todo mundo se comunica muito bem, tudo muito normal. A gente senta à mesa junto, come junto, ele se serve, ele come muito bem e ele conversa com a gente na mesa, mas daquele jeito, ele está olhando, mas ele conversa normal, é muito legal. Então todo mundo conversa com ele normalmente, da nossa casa, irmãos. Agora as outras pessoas, vô, tios, aí a gente tem que ficar ajudando a comunicação, mas dentro de casa todo mundo sabe. 
Os tios, nenhum sabe. De parente é assim: -o que o Jorge está falando? O que ele quer? Então eu ensino os sinais, mas não é aquele tempo d'eu parar e ensinar. É sempre assim, a gente tem que ensinar. Quando ele fica na casa de alguém, eu deixo sempre a Josi. Se eu preciso fazer alguma coisa, é ela quem ensina as pessoas. É assim, no geral não tem como ensinar. Eu tenho o dicionário em casa, mas eu o uso. Então as pessoas estão aprendendo com a convivência com ele, ele ensina, ele mostra pras pessoas.

B) José - pai do Jorge

Meu nome é José, sou pai do Jorge, nós estamos aqui na USP há 4 anos e pelo tempo que nós estamos aqui estou vendo que meu filho está progredindo muito e desde o início nossas expectativas foram atendidas dentro daquilo que a gente esperava.

A primeira pessoa que percebeu que o Jorge não escutava fui eu. Quando ele nasceu eu o chamava e ele virava, e com o tempo ficamos na desconfiança. Ele estava no prezinho e teve otite, eu batia palma, fazia som, e ele não tinha reação nenhuma. Depois de 15 dias nós fomos ao hospital pra ver essa otite. Ele teve febres altíssimas, e depois a coisa se agravou, e confirmou mesmo que ele não estava ouvindo, que tinha uma perda. Aí fomos atrás e chegamos até aqui. Ele tinha um ano, um ano e pouco e nós estávamos fazendo tratamento na Santa Casa, lá no Centrinho. 
Para comprarmos o primeiro aparelho do Jorge, fizemos uma lista no prédio e fizeram essa doação, e é esse aparelho que ele usa até hoje, e agora nós estamos brigando para ver se conseguimos um outro.

O Jorge não usa muito o aparelho em casa, é raro. Ele usa mais para vir para cá, na USP e para escola. Tem horas que ele mesmo tira e às vezes ele pede para colocar, mas é muito raro, muito difícil.

Eu sinto que ele ouve quando está com o aparelho, mas não sei se incomoda, ou alguma coisa assim, então vê como obrigação e só quando vai para escola ou para vir para cá, mas a gente acha que há uma mudança, que ele busca mais coisas. Hoje o aparelho está quebrado, mas normalmente ele o usa quando vai para escola (das 13horas às 15horas).

Quando ele está com o aparelho ele fica com ele direto e quando vem às vezes emenda. É muito relativo, tem dias que ele não quer e tira, mas de $2^{\mathrm{a}}$ e $4^{a}$ quando ele vem de manhã, ele fica o dia inteiro até chegar da escola. A hora que chega da escola ele tira, mas mesmo assim, a nossa comunicação não muda porque a gente vai mais na parte de sinais e agora ele evoluiu muito. A gente está muito feliz com ele, porque ele está conseguindo muitas coisas e vem as especulações. Agora ele quer saber, quer que a gente fale para ele, está naquela ansiedade. 
Em relação a um tratamento fonoaudiológico, se for mesmo a fundo foi aqui mesmo. O início de tudo foi aqui. Antes, lá na Santa Casa ele participou mais na parte dos exames, BERA, audiometria aquele negócio todo. Lá na Santa Casa nós nem sabíamos que existia a USP, mas por conseqüência de estar no mesmo espaço que outras pessoas, alguém indicou dizendo que tinha essa parte de fono aqui na USP, e então fui atrás, porque eu não queria ver meu filho parar no tempo, no espaço. Quanto mais tarde, as coisas vão se agravando.

E eu esperava o que eu estou vendo agora, uma evolução enorme. Estou sentindo que meu filho pode falar como a professora surda. Eu o vejo como a professora mais para frente, no futuro, como vejo outras crianças. 0 potencial dele é muito grande e com vocês dando essa força, acho que as coisas vão caminhar e vamos chegar lá.

A gente trabalha com os dois lados, a gente fala e ele já está fazendo uma leitura, muitas coisas a gente nem precisa usar sinais, ele já sabe. Então a gente trabalha os dois lados, a Língua Oral e de Sinais, assim a interação entre a gente é aceitável, acho que a gente consegue tudo aquilo que a gente quer dentro do possível. A gente se entende muito bem, como vocês mesmo podem ver na nossa participação. Acho que tem que usar aquilo que estamos absorvendo aqui, botar em prática o que vocês passam para nós, senão a coisa não flui. Não adianta nada você pegar e ficar parado e não forçar aquilo, acho que você tem que insistir para você ver a coisa andar. 
Em casa, com todos é igual, lá não tem exceção. Desde a menina até o rapaz a comunicação é a mesma. Todo mundo se entende. Se temos dúvidas nós mesmo tiramos. Às vezes escapa, então um ajuda o outro. O que ele não consegue buscar nos lábios, ele vai com os sinais, a gente explica para ele, mostra.

A Língua de Sinais, para mim foi maravilhosa e para ele também, porque é a maneira da gente se comunicar e é como a professora surda ensinou, não adianta a gente criar o próprio método da gente se existe uma linguagem universal, então você tem que usar aquele que está certo.

Eu dou muito valor para as reuniões do grupo de pais. É como a gente fala, nós temos a nossa família, nossa esposa, filhos, mas aqui, de $4^{a}$ feira é uma família mesmo. Acho que um ajudando o outro, isso é MUITO importante, a troca de informações, a gente fica ouvindo, às vezes a gente se abre e eu acho que é bom para os nossos filhos e para nós, pais, essa troca de informações.

Depois de começarmos aqui, a comunicação mudou, ficou outra, é bem mais fácil. Antigamente eu falava de uma maneira, o outro falava de outra, o outro falava de outra, criava-se uma certa uma confusão. Agora, então, existe uma coisa padronizada então é bem mais fácil. 
A expectativa é o que estou falando. Eu já coloco a coisa bem lá para frente. É como eu vejo, às vezes saio e vejo uma criança, menino, menina, nos seus 12, 13 anos, e eu tenho muito prazer em ver que meu filho está nesse estágio e eu sei que ele vai chegar lá, falta tão pouco, então para isso a gente persiste e vem mesmo. Se for preciso vir a noite, não sei, eu quero ver meu filho da maneira como eu vejo fora, os outros, quero ver ele igual. E eu sei que vai ser sim, condições a gente tem dado. Meu único medo é uma incerteza de não saber se eu vou ou não vou ver meu filho. A cabeça fica meio, então isso dá uma garra, uma vontade de lutar, que eu brigo, brigo mesmo. Jorge é tudo para mim, eu jogo, exponho, jogo ele assim mesmo, é meu filho, e sinto um orgulho.

Eu queria fazer alguma coisa voltada para ele, procurar alguma coisa, tipo de investimento para as pessoas verem que existe essa camada tão pequena. As pessoas passam por cima, atropelam, não dão valor. As pessoas investem em coisas tão banais e há coisas muito mais úteis em que podiam investir. E eu gostaria de ajudar. Eu sinto que eu preciso fazer alguma coisa.

Mas em relação a vocês, agradeço de coração mesmo, se não fossem vocês, não acho que estaria nesse patamar hoje. Sei que tem que galgar mais alguns degraus, mas a gente vai chegar lá. 
5. Resultados 


\subsection{Resultados referentes às análises quantitativas e qualitativas}

\subsubsection{Análise intrafamiliar}

A partir de cada questão, foi observado que as respostas dadas pelos membros de mesma família, ora coincidem, ora não. Devido a essas diferenças, foram elaboradas as seguintes tabelas.

Tabela 5.1 Concordância intrafamiliar da questão 9

Seu filho usa os AASI em casa? Quanto tempo por dia ele usa o AASI? Qual a relação que ele tem com o aparelho? E você?

\begin{tabular}{|c|c|c|}
\hline Familia & Concorda & \\
\hline F1 & Não concorda \\
\hline F2 & $X$ & \\
\hline F3 & $X$ & \\
\hline F4 & $X$ & \\
\hline F5 & $X$ & \\
\hline F6 & $X$ & \\
\hline F8 & $X$ & \\
\hline F9 & $X$ & \\
\hline F10 & X & \\
\hline & & $X$ \\
\hline
\end{tabular}

Tabela 5.2 Concordância intrafamiliar da questão 10

A comunicação / interação entre vocês se altera quando ele está com os aparelhos?

\begin{tabular}{|c|c|c|}
\hline Família & Concorda & Não concorda \\
\hline F1 & $\mathrm{X}$ & \\
\hline F2 & $\mathrm{X}$ & \\
\hline F3 & $\mathrm{X}$ & \\
\hline F4 & & $\mathrm{X}$ \\
\hline F5 & & $\mathrm{X}$ \\
\hline F6 & $\mathrm{X}$ & \\
\hline F7 & $\mathrm{X}$ & \\
\hline F8 & $\mathrm{X}$ & \\
\hline F9 & $\mathrm{X}$ & \\
\hline F10 & \multicolumn{1}{|}{} \\
\hline
\end{tabular}


Tabela 5.3 Concordância intrafamiliar da questão 11

Como se estabelece a comunicação entre você e seu filho? Como se dá a interação entre vocês? Em que língua?

\begin{tabular}{|c|c|c|}
\hline Família & Concorda & Não concorda \\
\hline F1 & & $\mathrm{X}$ \\
\hline F2 & & $\mathrm{X}$ \\
\hline F3 & & $\mathrm{X}$ \\
\hline F4 & & $\mathrm{X}$ \\
\hline F5 & $\mathrm{X}$ & \\
\hline F6 & & $\mathrm{X}$ \\
\hline F7 & & $\mathrm{X}$ \\
\hline F8 & $\mathrm{X}$ & \\
\hline F9 & $\mathrm{X}$ & \\
\hline F10 & $\mathrm{X}$ & \\
\hline
\end{tabular}

Tabela 5.4 Concordância intrafamiliar da questão 12

Existe alguma forma (estratégia) para que essa comunicação se efetive (estabeleça)?

\begin{tabular}{|c|c|c|}
\hline Familia & Concorda & Não concorda \\
\hline F1 & & $\mathrm{X}$ \\
\hline F2 & & $\mathrm{X}$ \\
\hline F3 & & $\mathrm{X}$ \\
\hline F4 & & $\mathrm{X}$ \\
\hline F5 & $\mathrm{X}$ & \\
\hline F6 & $\mathrm{X}$ & $\mathrm{X}$ \\
\hline F7 & & $\mathrm{X}$ \\
\hline F8 & & \\
\hline F9 & $\mathrm{X}$ & $\mathrm{X}$ \\
\hline F10 & & \\
\hline
\end{tabular}

Tabela 5.5 Concordância intrafamiliar da questão 13

Como as outras pessoas da casa se comunicam com seu filho?

\begin{tabular}{|c|c|c|}
\hline Família & Concorda & Não concorda \\
\hline F1 & $X$ & \\
\hline F2 & $X$ & $X$ \\
\hline F3 & & $X$ \\
\hline F4 & & $X$ \\
\hline F5 & & \\
\hline F6 & $X$ & \\
\hline F7 & $X$ & \\
\hline F9 & $X$ & \\
\hline F10 & $X$ & \\
\hline
\end{tabular}


Tabela 5.6 Concordância intrafamiliar da questão 14

Como foi a aceitação ou não da Língua de Sinais? Como é a Língua de Sinais para você?

\begin{tabular}{|c|c|c|}
\hline Família & Concorda & Não concorda \\
\hline F1 & $\mathrm{X}$ & \\
\hline F2 & $\mathrm{X}$ & \\
\hline F3 & $\mathrm{X}$ & $\mathrm{X}$ \\
\hline F4 & & \\
\hline F5 & $\mathrm{X}$ & \\
\hline F6 & $\mathrm{X}$ & $\mathrm{X}$ \\
\hline F7 & $\mathrm{X}$ & $\mathrm{X}$ \\
\hline F8 & & \\
\hline F9 & & \\
\hline F10 & $\mathrm{X}$ & \\
\hline
\end{tabular}

Tabela 5.7 Concordância intrafamiliar da questão 15

Como você avalia as reuniões do grupo de pais?

\begin{tabular}{|l|l|l|}
\hline Família & Concorda & Não concorda \\
\hline F1 & $X$ & \\
\hline F2 & $X$ & \\
\hline F3 & $X$ & \\
\hline F4 & $X$ & \\
\hline F5 & $X$ & \\
\hline F7 & $X$ & \\
\hline F8 & $X$ & \\
\hline F9 & $X$ & \\
\hline F10 & X & \\
\hline
\end{tabular}

Tabela 5.8 Concordância intrafamiliar da questão 16

Você conversa com as outras pessoas da casa sobre o que foi discutido no grupo?

\begin{tabular}{|c|c|c|}
\hline Família & Concorda & Não concorda \\
\hline F1 & & X \\
\hline F2 & $\mathrm{X}$ & \\
\hline F3 & $\mathrm{X}$ & $\mathrm{X}$ \\
\hline F4 & & \\
\hline F5 & $\mathrm{X}$ & \\
\hline F6 & $\mathrm{X}$ & \\
\hline F7 & $\mathrm{X}$ & \\
\hline F8 & $\mathrm{X}$ & \\
\hline F9 & $\mathrm{X}$ & \\
\hline F10 & $\mathrm{X}$ & \\
\hline
\end{tabular}


Mudou alguma coisa na sua família depois que iniciou tratamento no laboratório?

\begin{tabular}{|c|c|c|}
\hline Família & Concorda & Não concorda \\
\hline F1 & & $\mathrm{X}$ \\
\hline F2 & & $\mathrm{X}$ \\
\hline F3 & & $\mathrm{X}$ \\
\hline F4 & $\mathrm{X}$ & \\
\hline F5 & $\mathrm{X}$ & $\mathrm{X}$ \\
\hline F6 & & $\mathrm{X}$ \\
\hline F7 & & $\mathrm{X}$ \\
\hline F8 & & \\
\hline F9 & $\mathrm{X}$ & $\mathrm{X}$ \\
\hline F10 & & \\
\hline
\end{tabular}

Tabela 5.10 Concordância intrafamiliar da questão 18

Hoje, quais são as suas expectativas?

\begin{tabular}{|c|c|c|}
\hline Família & Concorda & Não concorda \\
\hline F1 & $\mathrm{X}$ & $\mathrm{X}$ \\
\hline F2 & & \\
\hline F3 & $\mathrm{X}$ & $\mathrm{X}$ \\
\hline F4 & & $\mathrm{X}$ \\
\hline F5 & & $\mathrm{X}$ \\
\hline F6 & & $\mathrm{X}$ \\
\hline F7 & & $\mathrm{X}$ \\
\hline F8 & & \\
\hline F9 & $\mathrm{X}$ & $\mathrm{X}$ \\
\hline F10 & & \\
\hline
\end{tabular}

Gráfico 5.1 Concordância intrafamiliar das respostas dadas

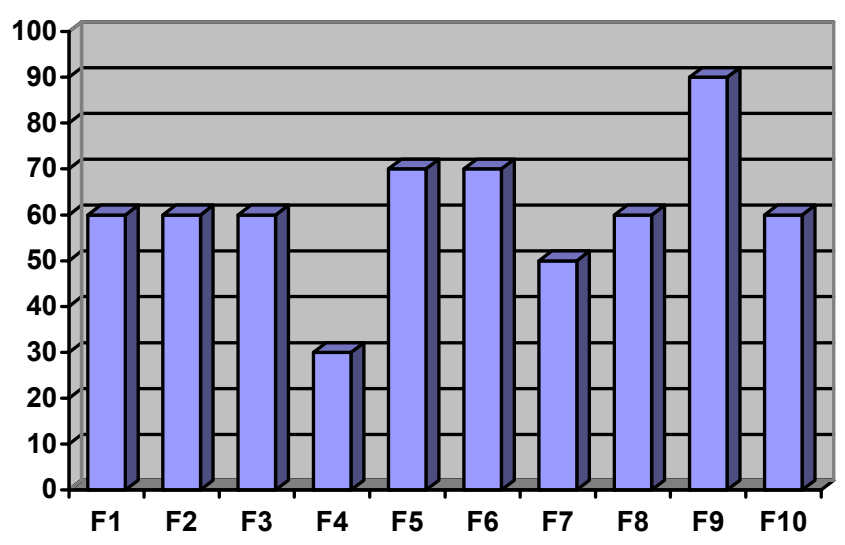

$\%$ DE

CONCORDÂNCIA 
Dentre as dez famílias entrevistadas, uma apresenta concordância em $90 \%$ das respostas dadas, em duas famílias $70 \%$, em cinco famílias $60 \%$, uma em $50 \%$ e também uma família concorda em apenas $30 \%$ das informações dadas.

Com base nesses dados, é possível verificar que a porcentagem de concordância entre os membros da mesma família, apesar de ser na maior parte dos casos maior que $50 \%$, ainda é uma porcentagem baixa.

É importante ressaltar que grande parte dos entrevistados colocou que conversa com os outros membros da família apenas às vezes e quando se tem tempo. Esse fato pode ser melhor evidenciado se tomarmos como exemplo a F4 que nos depoimentos de seus membros mostrou a falta de diálogo em casa entre os mesmos e apresentou concordância em apenas 30\% das respostas.

\subsubsection{Análise entre as famílias do Grupo Direto e Grupo Indireto}

\section{Questão 9 do Grupo Direto}

Seu filho usa os AASI em casa? Quanto tempo por dia ele usa o AASI? Qual a relação que ele tem com o aparelho? E você? 
Gráfico 5.2 - \% das respostas dadas a questão 9 pelo Grupo Direto

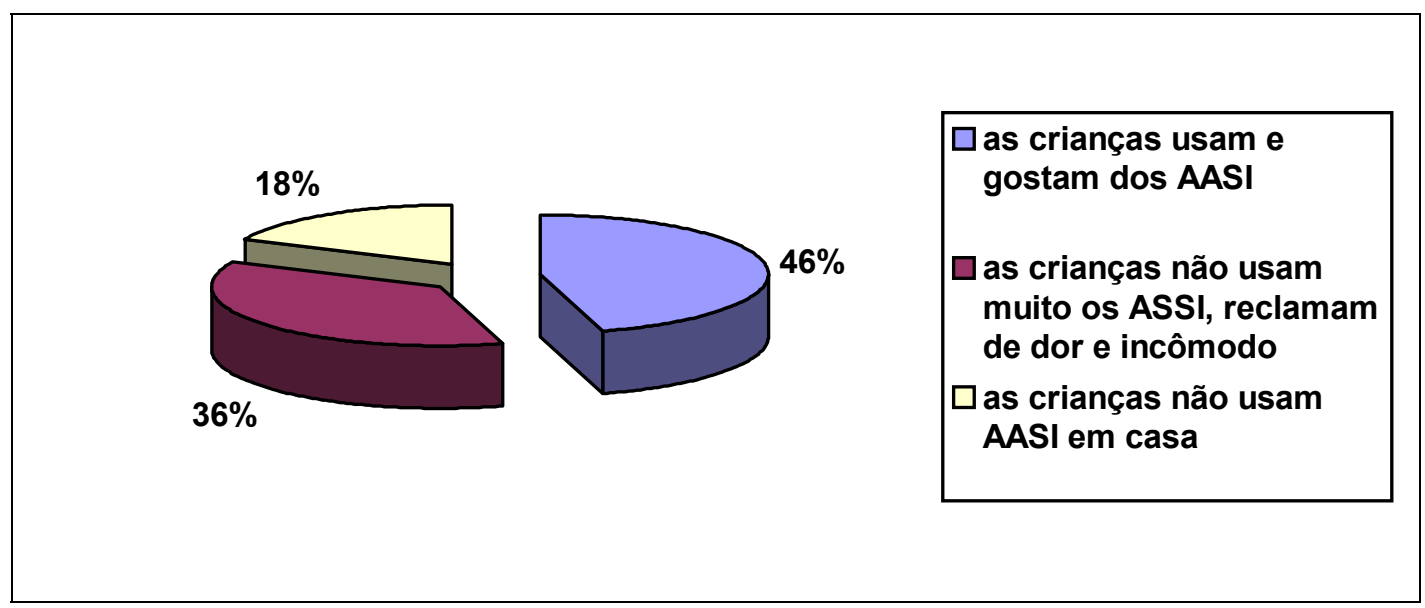

Discurso Coletivo 1

Em casa ele tira o aparelho só para dormir e tomar banho. Ele usa direto, nunca desgruda dele. Ele gosta do aparelho, gosta bastante. Quando levanta da cama já vai direto buscar o aparelho, não precisa ninguém mandar. Ele se sente bem com o aparelho. Gosta muito de ver televisão, de ouvir os outros falarem. Ele diz que com o aparelho ele ouve e sem, ele diz que não tem nada. Quando a gente esquece de colocar, ele pergunta: -Cadê o papapa? Então a gente percebe que ele sente falta.

\section{Discurso Coletivo 2}

Em casa, dificilmente ele usa o aparelho, é bem pouco, é raro, mesmo sabendo cuidar dele sozinho. Ele vê como obrigação e usa mais para vir para cá, na USP e para ir à escola. Quando ele não vem para a fono, às vezes fica sem o aparelho, e eu mesmo acabo esquecendo de fazer com que ele o coloque. Ele não tem uma boa aceitação do aparelho. Ele não gosta de usá-lo, diz que incomoda, tem dores de cabeça e desconforto. Só usa quando quer. 
Acho que por causa do barulho. Eu até gosto que ele use o aparelho porque é uma coisa científica e a gente tem que aceitar. Por mim ele só tirava o aparelho para dormir e tomar banho, mesmo não tendo visto grande melhora nele com o aparelho.

\section{Discurso Coletivo 3}

Ele não quer usar aparelho em casa. A gente reclama com ele e ele diz que não gosta. Não quer. Ele tira porque está suando, às vezes já vem na caixinha, é assim que ele faz. Eu gosto do aparelho, mando ele colocar, digo que é bom, mas ele não aceita, não quer aceitar.

\section{Questão 9 do Grupo Indireto}

Seu filho usa os AASI em casa? Quanto tempo por dia ele usa o AASI? Qual a relação que ele tem com o aparelho? E você?

Gráfico 5.3 - \% das respostas dadas a questão 9 pelo Grupo Indireto

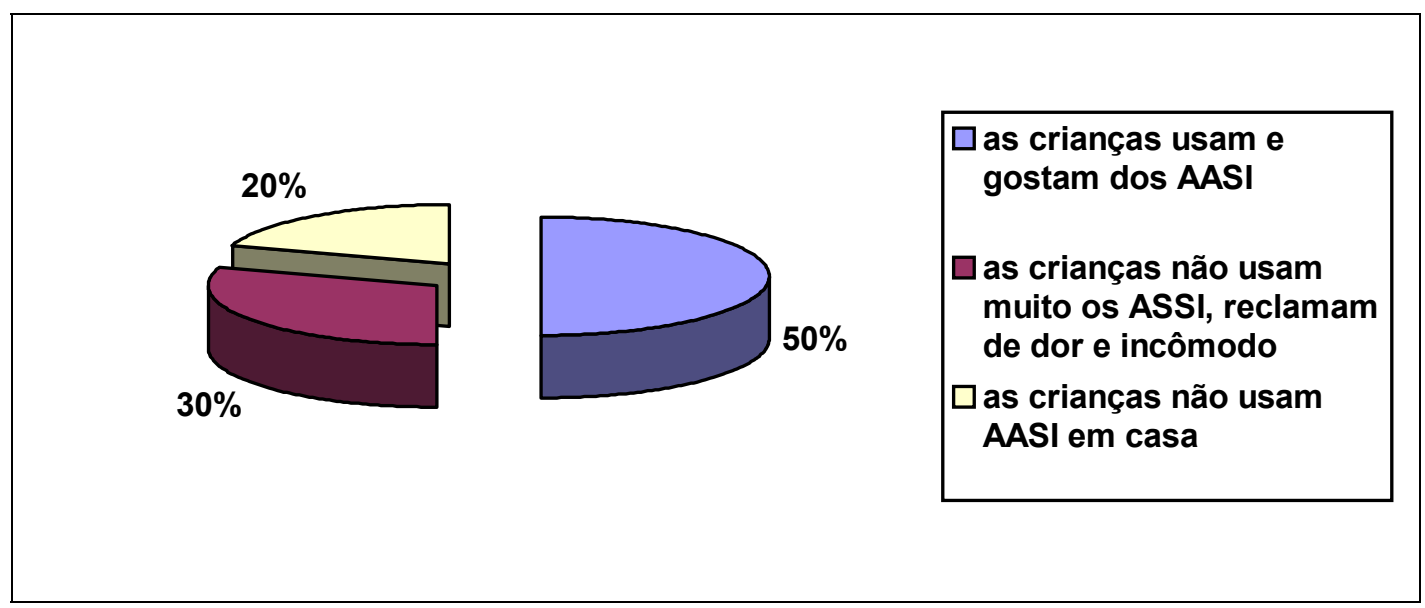




\section{Discurso Coletivo 1}

Em casa, ele usa o aparelho e até pede para que seja colocado principalmente quando ele está ouvindo desenho ou alguma coisa assim. Ele tem tomado iniciativa e ele mesmo já sabe colocar. E ele gosta do aparelho. Ele não reclama do aparelho não. Quando ele está com aparelho é como se ele estivesse normal, assim, sem nada. E ele usa o aparelho o dia todo, só tira quando vai tomar banho. Às vezes eu vou ligar o som e ele está sem o aparelho, ele vai lá e pega o aparelho.

\section{Discurso Coletivo 2}

De vez em quando, ele usa o aparelho em casa. Ele não usa muito. Ele usa mais quando vai para escola. Ele não gosta e não é sempre que ele usa não. A gente tenta colocar, ele fala que não, que ele só coloca na escola. Ele fala que incomoda, que dói.

\section{Discurso Coletivo 3}

Ele não quer usar o aparelho, nem em casa, nem na escola, nem pra vir pra cá e nem em nenhum lugar. Ele não consegue ficar com ele. Você coloca e ele tira. Ele se incomoda com o aparelho, ele falou que não gosta de usar. Ele não usa, mas por mim ele usaria normalmente, não tem porque não usar. 


\section{Questão 10 do Grupo Direto}

A comunicação / interação entre vocês se altera quando ele está com os aparelhos?

Gráfico 5.4 - \% das respostas dadas a questão 10 pelo Grupo Direto

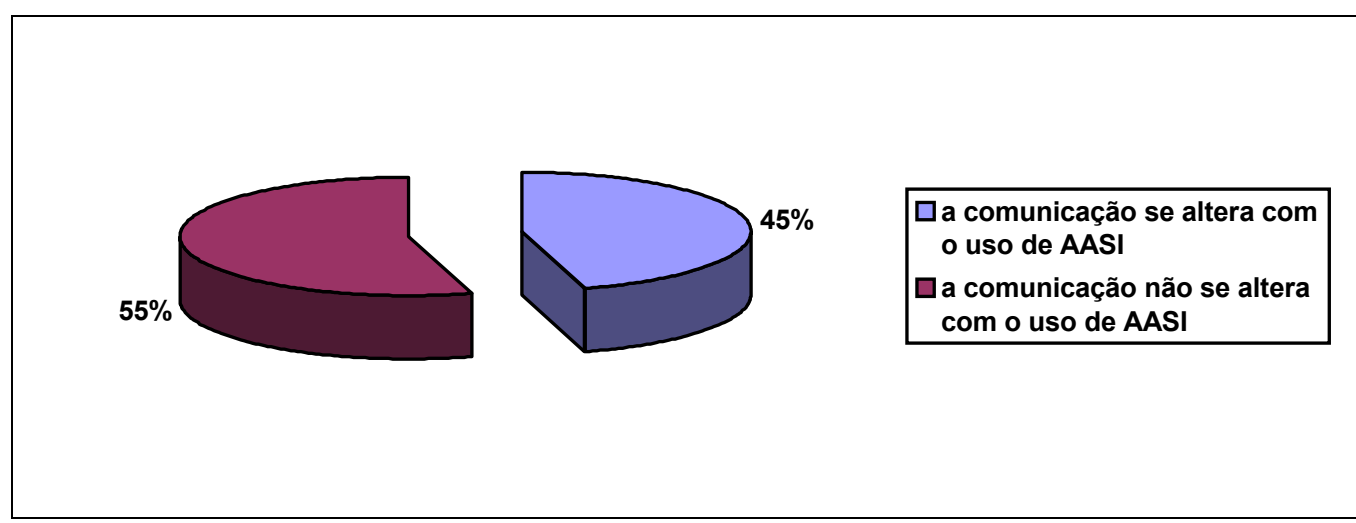

Discurso Coletivo 1

A comunicação é a mesma, a gente não sente diferença alguma quando ele está com ou sem aparelho, pois eu faço as duas juntas, a Língua de Sinais e a Oral, às vezes eu até esqueço de falar.

\section{Discurso Coletivo 2}

O aparelho muda muito. A nossa comunicação é diferente quando ele está com ou sem aparelho. Ela muda porque quando ele está de aparelho, ele localiza os barulhos e presta mais atenção no som que está saindo da boca. Sem o aparelho ele só olha para as mãos e às vezes não percebe que a gente está conversando com ele. Com o aparelho ele percebe o som e ele fala, quando ele está com o aparelho ajuda muito, com o aparelho é melhor. 


\section{Questão 10 do Grupo Indireto}

A comunicação / interação entre vocês se altera quando ele está com os aparelhos?

Gráfico 5.5 - \% das respostas dadas a questão 10 pelo Grupo Indireto

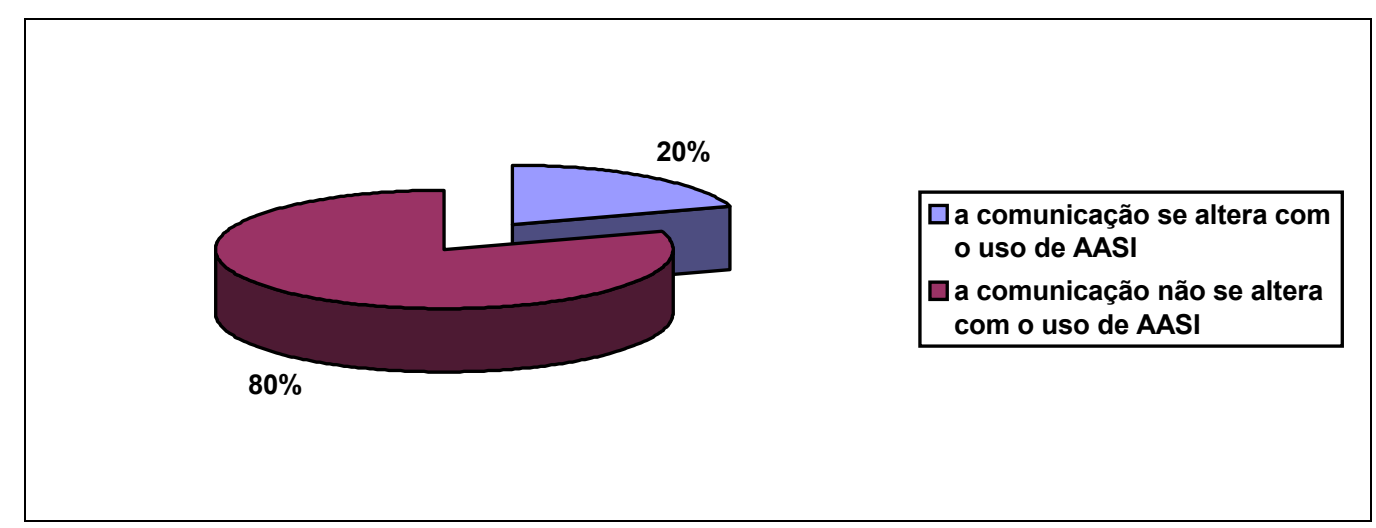

Discurso Coletivo 1

A comunicação não muda e a gente conversa da mesma forma quando ele está com ou sem o aparelho. Eu falo do mesmo jeito com ele, por sinais ou olhando para ele e falando. Eu sempre tento me comunicar com ele de um jeito que ele me entende.

\section{Discurso Coletivo 2}

Quando ele está de aparelho, ele escuta e eu procuro falar mais com ele, evito os sinais. Agora quando ele não está, ele não escuta não e aí muda o jeito d'eu falar com ele porque ela não escuta. Eu vou lá, eu toco nele e com o aparelho, eu chamo e ele escuta. 
Comentário

"O aparelho pouco ajuda e eu acho que sem o aparelho, ela se comunica mais."

\section{Questão 11 do Grupo Direto}

Como se estabelece a comunicação entre você e seu filho? Como se dá a interação entre vocês? Em que língua?

Gráfico 5.6 - \% das respostas dadas a questão 11 pelo Grupo Direto

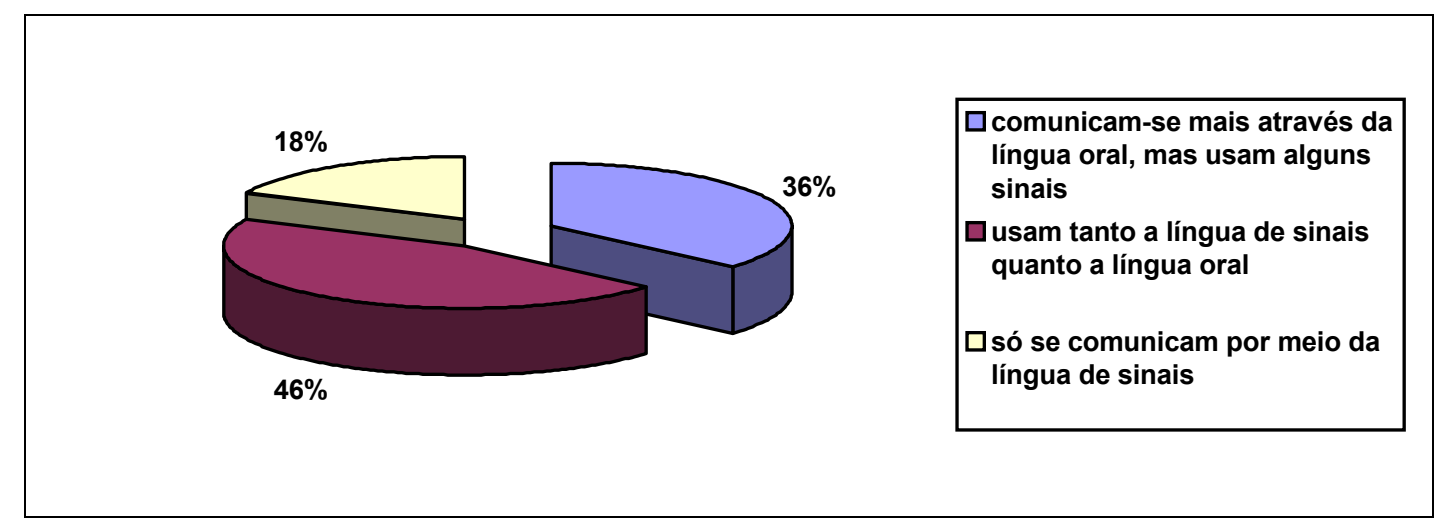

Discurso Coletivo 1

Em casa geralmente a gente conversa só falando, como a gente está conversando, como se fosse entre duas pessoas normais. Quando ele não entende, ele pede para fazer algum sinal e a gente consegue se entender.

\section{Discurso Coletivo 2}

A nossa interação se dá mais por sinais, apesar de que eu não consigo só fazer os sinais, mas eu entendo bem e ele também entende as respostas que eu dou. Ele usa muitos sinais e ele fala, da maneira dele, ele vai falando 
junto com os sinais. A gente, então, trabalha com os dois lados, a Língua Oral e de Sinais. Ao mesmo tempo em que vou fazendo sinais, eu vou falando, assim a interação entre a gente é aceitável, acho que a gente consegue tudo aquilo que a gente quer dentro do possível.

\section{Discurso Coletivo 3}

Hoje a nossa comunicação é perfeita. Só em sinais, mas é perfeita. 0 que eu não sei em sinais, eu procuro um jeito para fazer ele entender. É lógico que eu não sei tudo, porque tem pouco tempo que eu estou firme e forte nos sinais, mas eu entendo tudo o que ele quer.

\section{Questão 11 do Grupo Indireto}

Como se estabelece a comunicação entre você e seu filho? Como se dá a interação entre vocês? Em que língua?

Gráfico 5.7 - \% das respostas dadas a questão 11 pelo Grupo Indireto

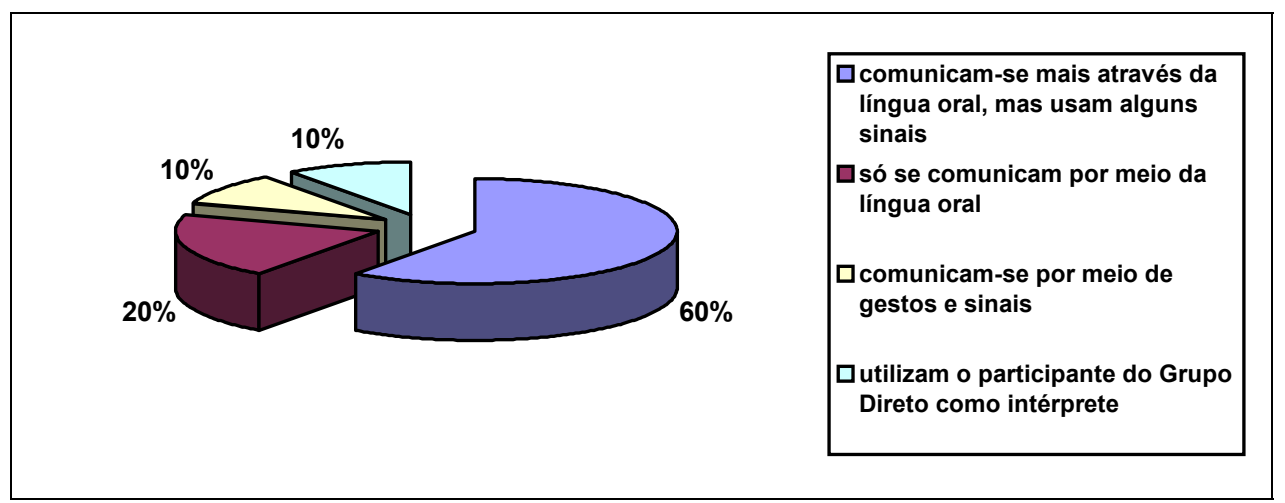




\section{Discurso Coletivo 1}

Eu falo normal com ele. Não falo por gestos. 'As vezes ele entende. É muito difícil d'eu falar em Língua de Sinais com ele, muito difícil mesmo.

\section{Discurso Coletivo 2}

A gente se comunica bem. Mesmo falando, ele me entende, mas é mais de observação mesmo. Ele lê os lábios da gente. Eu procuro sempre falar com ele. Quando eu não consigo, eu tento fazer LIBRAS e às vezes eu faço errado e ele me corrige. O que eu sei é o que ele me ensina. Por isso a nossa comunicação às vezes é um pouco complicada porque eu não sei tudo de Língua de Sinais, mas aí eu falo para ele que eu não sei. Às vezes ele fica irritado, bravo, quando ele percebe que eu não sei. Aí eu peço para ele explicar para mim o que ele quer, daí ele vai e faz eu entender.

\section{Comentário 1}

"A gente se comunica por gestos, Eu não sei muitos sinais, mas o que eu sei já dá para nos entendermos muito."

\section{Comentário 2}

"Eu não sei fazer sinais, mas quando é alguma coisa que eu quero falar para ela eu pergunto para a mãe." 


\section{Questão 12 do Grupo Direto}

Existe alguma forma (estratégia) para que essa comunicação se efetive (estabeleça)?

Gráfico 5.8 - \% das respostas dadas a questão 12 pelo Grupo Direto

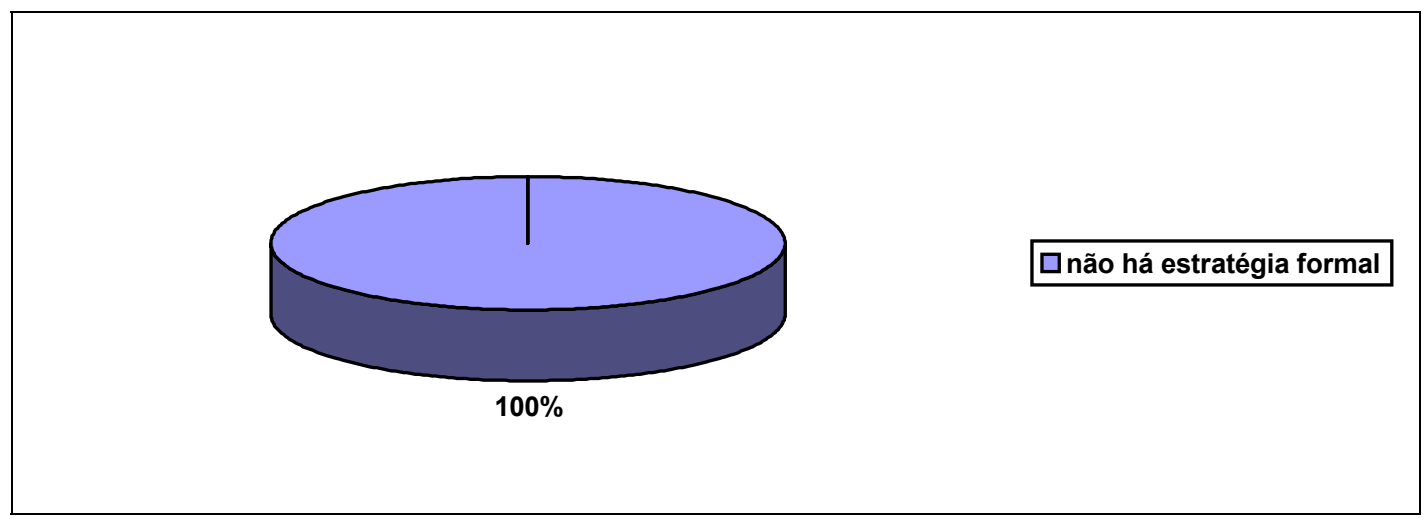

Discurso Coletivo

A nossa comunicação é natural, não tem nenhuma estratégia, a gente deixou acontecer, naturalmente. Acho que é do dia a dia, é de olhar para ele. 0 que eu percebo muito é que ele gosta que você fique olhando, então, a gente estabeleceu assim, de olhar um para o outro. Se você não olhar, ele não fala. Acho que é um jeito dele achar que você está prestando atenção realmente e não só escutando por escutar.

Toda hora ele chama, tudo ele mostra, tudo ele pergunta, tudo ele escreve, tudo ele desenha.

Acho que tem que usar aquilo que estamos absorvendo aqui, então eu vou seguindo conforme a gente vai aprendendo, com a Língua de Sinais. Se ele não consegue falar alguma coisa, ele faz sinais para mim, se eu acho que é mais fácil fazer os sinais para ele, eu faço o sinal, se não é, eu falo. 
Quando eu não entendo, peço para ele me mostrar o que ele está querendo falar, peço que ele me mostre, para eu poder entender bem o que ele quer, ou ele fala devagar e tenta explicar melhor e aí a gente acaba se entendendo. Às vezes faço umas mímicas, pego um negócio para ele conseguir me entender ou eu pergunto para os professores de Língua de Sinais, então a minha comunicação com ele é muito boa. Eu nunca tive problemas.

\section{Questão 12 do Grupo Indireto}

Existe alguma forma (estratégia) para que essa comunicação se efetive (estabeleça)?

Gráfico 5.9 - \% das respostas dadas a questão 12 pelo Grupo Indireto

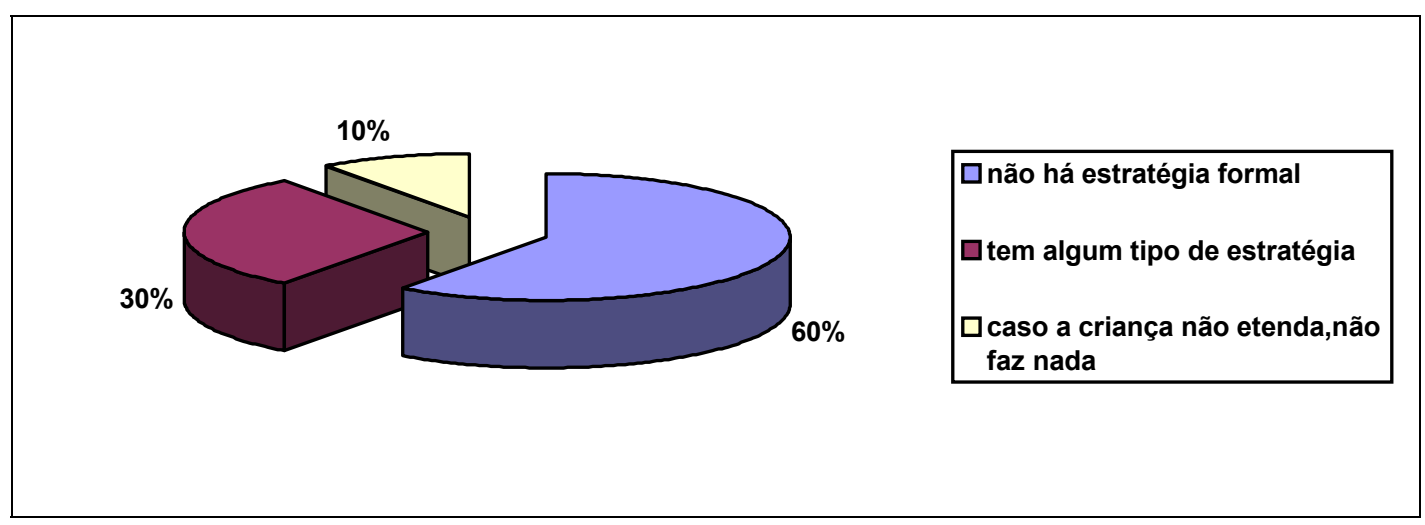

Discurso Coletivo 1

A gente não estabeleceu, não existe uma regra ou estratégia especial, a comunicação se dá pelo dia a dia. Eu acho que o que for mais fácil para ele e para mim e a gente se entender, está bom. Eu não freqüento aula de Língua de Sinais então foi natural, a forma da gente se comunicar. Eu não tenho como 
usar uma estratégia nova para falar com ele, eu estou aprendendo com ele, tanto com ele, como aqui dentro.

Eu falo mais com ele, eu não falo tanto por sinais, eu falo quando eu estou bravo, e ele sabe que estou bravo. Eu falo que não, ele já entende. Assim, por sinais também, o que eu não sei de sinais, eu falo para ele. Quando eu quero falar e ele não está prestando atenção, eu vou até ele e toco nele

\section{Discurso Coletivo 2}

A estratégia que existe é vendo o que ele entende melhor, o gesto, as coisas. Eu procuro falar de frente para ele, para ele ver meus lábios batendo e fazendo sinal. Muitas vezes eu faço sinais errados e ele me ensina, fala que está errado. Quando ele faz um gesto ou um sinal novo e eu não sei o que é, ele explica o que ele quer e o que ele não quer. E então eu acho que eu me comunico muito bem com ele. Muitas vezes eu falo e ele entende, mas mais de observação mesmo. Ele observa muito a gente. Ele lê os lábios da gente.

Eu não sei fazer sinais, mas quando é alguma coisa que eu quero falar para ele, eu pergunto para a mãe e no convívio também você vai aprendendo, é assim que nos comunicamos.

\section{Comentário}

“Agora tem coisas que ela não entende, aí ela faz gestos, às vezes eu entendo também, às vezes não entendo, aí quando não entendo, fica por isso mesmo." 


\section{Questão 13 do Grupo Direto}

Como as outras pessoas da casa se comunicam com seu filho?

Gráfico 5.10 - \% das respostas dadas a questão 13 pelo Grupo Direto

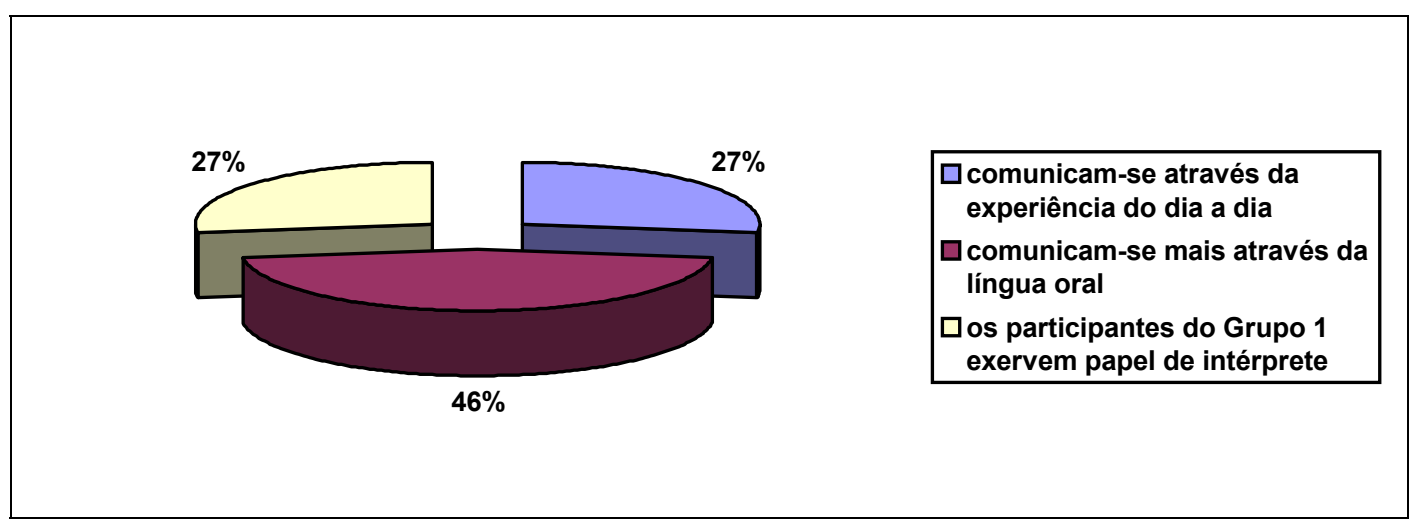

Discurso Coletivo 1

Todo mundo em casa se comunica por sinais e falando, é tudo junto, o que as pessoas não sabem ou eu ou ele ensina. Então as pessoas estão aprendendo com a convivência com ele. Ele ensina, ele mostra pras pessoas. O pai, por ele não ter muito contato que nem eu que saio sempre com ele, está aprendendo no dia a dia, comigo em casa e com ele mesmo, porque ele pega na mão dele e ensina a fazer os sinais

\section{Discurso Coletivo 2}

Em casa as pessoas se comunicam com ele da mesma forma. Eles falam, conversam normal e ele o entende $\dot{E}$ mais oral porque as outras pessoas não vêm aqui para aprender os sinais, então elas tentam falar porque não sabem muitos sinais. E ele só conversa falando mesmo, em casa. 


\section{Discurso Coletivo 3}

De parente é assim, eu ensino os sinais. É sempre assim, a gente tem que ensinar. Quando eles têm alguma dúvida, eles vêm perguntar pra mim. Eles perguntam como é que faz isso, como é que tem que falar aquilo e aí eu vou ajudando. O que eles não entendem, ele tenta falar para mim, para eu passar pros outros. Então é meio assim, ele passa por mim para chegar nos outros se não, dos outros passa por mim, para chegar a ele, é meio difícil por causa disso. Ninguém se interessa muito em saber sinais, essa é a realidade.

\section{Questão 13 do Grupo Indireto}

Como as outras pessoas da casa se comunicam com seu filho?

Gráfico 5.11 - \% das respostas dadas a questão 13 pelo Grupo Indireto

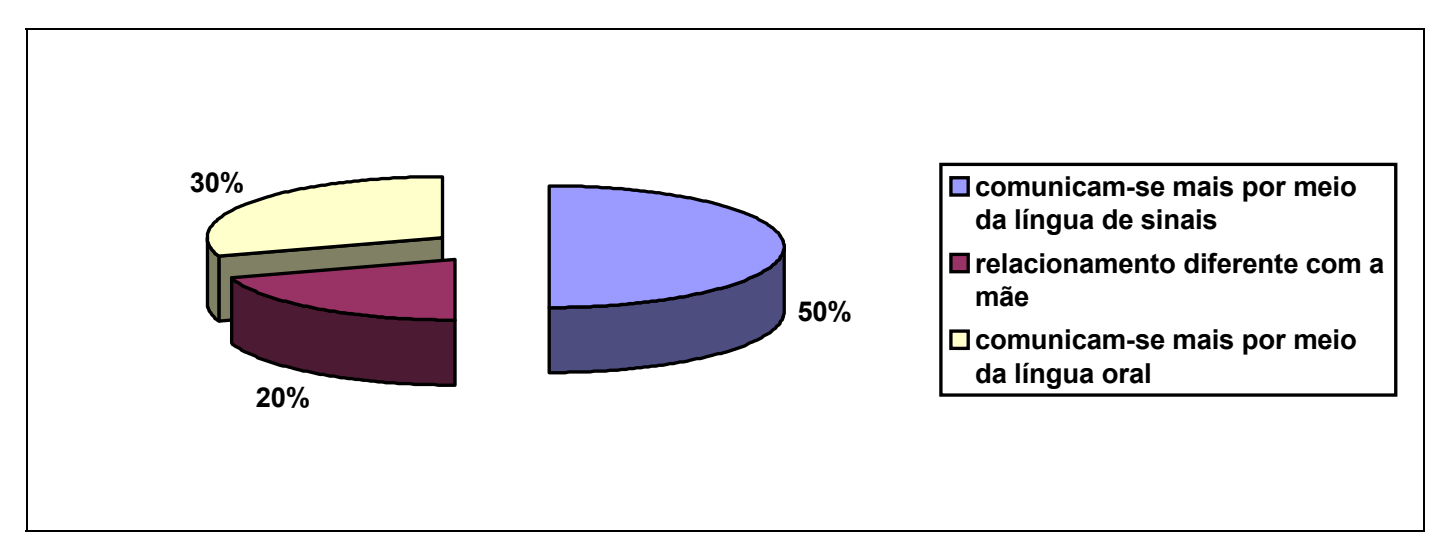

Discurso Coletivo1

As outras pessoas da casa se comunicam da mesma forma. Conversam com ele falando e usando sinal. Olham para ele e ele entende e ele lê os lábios. Eles usam vários sinais porque eles sabem mais, então é mais por 
sinais, mesmo. Falar, é pouca coisa. Acho que o pior é comigo mesmo. Os irmãos às vezes fazem sinais.

\section{Discurso Coletivo2}

A pessoa que mais se comunica com ele é a mãe porque convive mais com ele. Ela tem mais o jeito especial e como mãe, ela entende mais, conversa mais com o filho. Então é diferente. Algumas coisas que ele fala, eu não entendo, mas a mãe entende tudo. Ela fala mais próximo dele e eu vejo que ele repete as palavras algumas vezes. A mãe tem esse jeito de falar com ele, um jeito assim um pouco diferenciado.

Discurso Coletivo 3

O resto é tudo assim, passam algumas coisas para ele em Língua de Sinais, às vezes conversam por gestos, mas é mais falando, porque eles sabem muito pouco de LIBRAS.

\section{Questão 14 do Grupo Direto}

Como foi a aceitação ou não da Língua de Sinais? Como é a Língua de Sinais para você? 
Gráfico 5.12 - \% das respostas dadas a questão 14 pelo Grupo Direto

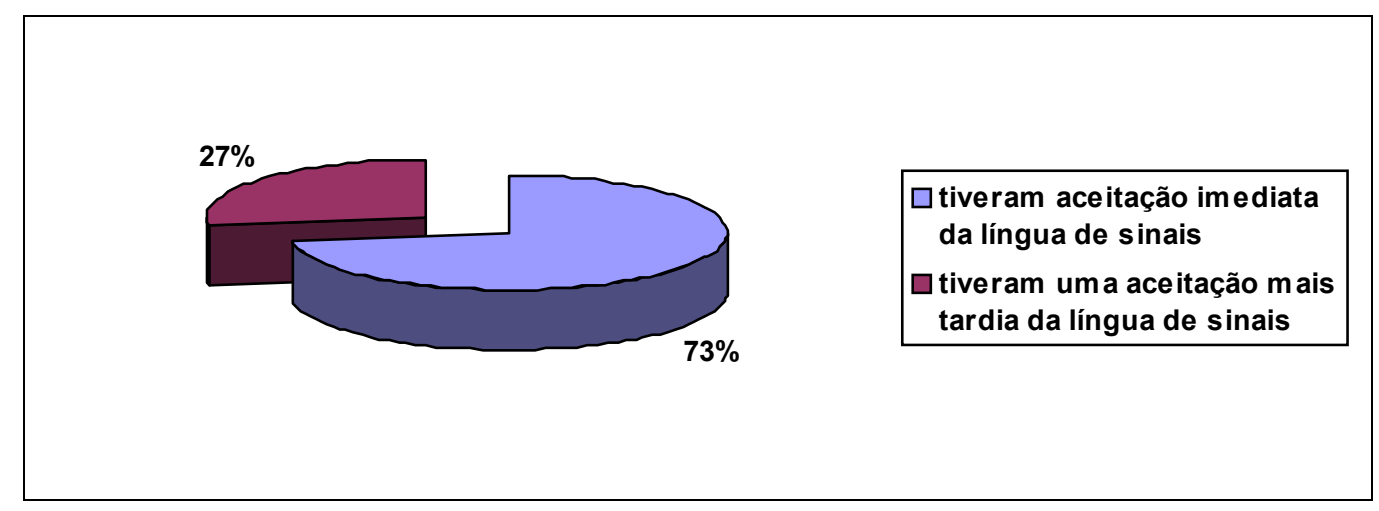

Discurso Coletivo 1

Aceitar a Língua de Sinais foi meio difícil no início. A gente acha um pouquinho estranho, mas eu tinha que arrumar um jeito de falar com ele e essa foi a minha motivação para aceitar. No começo eu não entendia e foi depois que eu caí na real de que tinha que aprender. Tem que aprender não, é bom aprender. E hoje eu vejo como são importantes os sinais, porque tudo em casa é por sinais, tudo. E é muito bom porque você consegue conversar com as crianças e com algumas pessoas. No começo foi porque era preciso, agora não. Com o tempo eu fui gostando, fui conversando com outras pessoas surdas e agora eu adoro.

\section{Discurso Coletivo 2}

Eu aceitei a Língua de Sinais rápido, numa boa. Comecei a pesquisar e a ver que era a língua deles mesmo. Acho que é uma nova língua para mim, mas para ele não, é a primeira língua, então a gente tem que aceitar. Ainda não sei tudo, mas o que eu não sei eu tento aprender. Conheci a professora 
surda e eu nunca tinha tido contato com surdos. A minha visão lá fora era bem diferente, difícil, mas e eu achava bonito, sempre admirei. A cada dia quero aprender mais, busco sempre e o que eu quero é aprender mais e mais. É um pouco difícil, mas a Língua de Sinais, para mim foi maravilhosa e para ele também, porque é a maneira da gente se comunicar e é como a professora ensinou, não adianta a gente criar um método próprio da gente se existe uma linguagem universal.

\section{Questão 14 do Grupo Indireto}

Como foi a aceitação ou não da Língua de Sinais? Como é a Língua de Sinais para você?

Gráfico 5.13 - \% das respostas dadas a questão 14 pelo Grupo Indireto

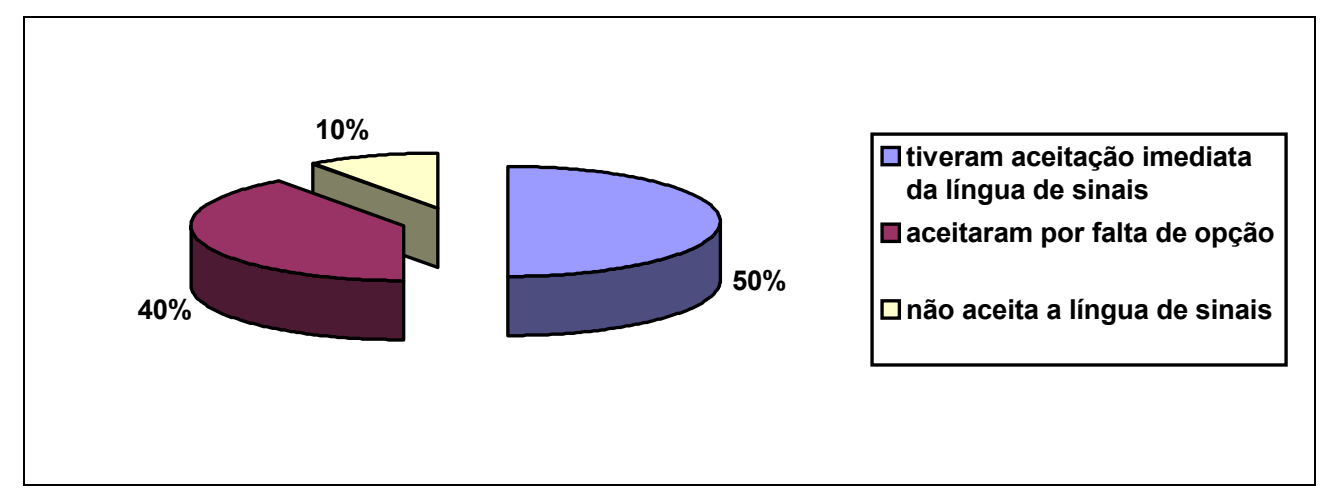

Discurso Coletivo 1

Em relação à Língua de Sinais, eu aceitei bem. Eu só não conheço muito bem e ainda tenho dificuldade em lembrar alguns sinais, tanto é que o meu filho fala que eu não aprendo, que eu preciso aprender o certo. 
Eu sei que vou ter que fazer um curso, ou conviver mais com os surdos, não só com o meu filho, mas com os colegas dele e outras pessoas deficientes auditivas. É um pouco complicado, porque eu o vejo falando com os coleguinhas de forma diferente de como fala com a gente, mas a aceitação foi boa.

Se eu pudesse, eu vinha toda segunda feira, pois aprendi um monte de coisas, é outro mundo, eu gosto! Acho que a Língua de Sinais é importante, principalmente para se comunicar. Nossa, é muito bom isso!

\section{Discurso Coletivo 2}

No começo eu queria que ele desenvolvesse a fala. Por mim eu não aceitava, para que Língua de Sinais? Mas a gente, nesse mundo, tem que aceitar tudo porque não tem opção e com o passar do tempo vi que era o melhor pra ele, que é a língua que ele tem mesmo para se comunicar e o que for melhor pra ele, eu estou junto. Ele não é o primeiro que nasceu desse jeito. Eu já vi muitos assim, mas só que eu nunca tive a oportunidade de falar em sinais com eles, então a gente tem que aceitar do jeito que vier e é o único jeito que ele tem de se expressar.

\section{Comentário}

"Voltando um pouco... Não é bem a Língua de Sinais que eu não aceito, é mais por ela ser surda. Eu não consigo aceitar, eu não consigo. Eu vejo que pode até ser egoísmo da minha parte, eu sei, mas é tão difícil aceitar 
que sua filha é surda, é muito difícil. Eu não consigo, não consigo, ainda não aceito."

\section{Questão 15 do Grupo Direto}

Como você avalia as reuniões do grupo de pais?

Gráfico 5.14 - \% das respostas dadas a questão 15 pelo Grupo Direto

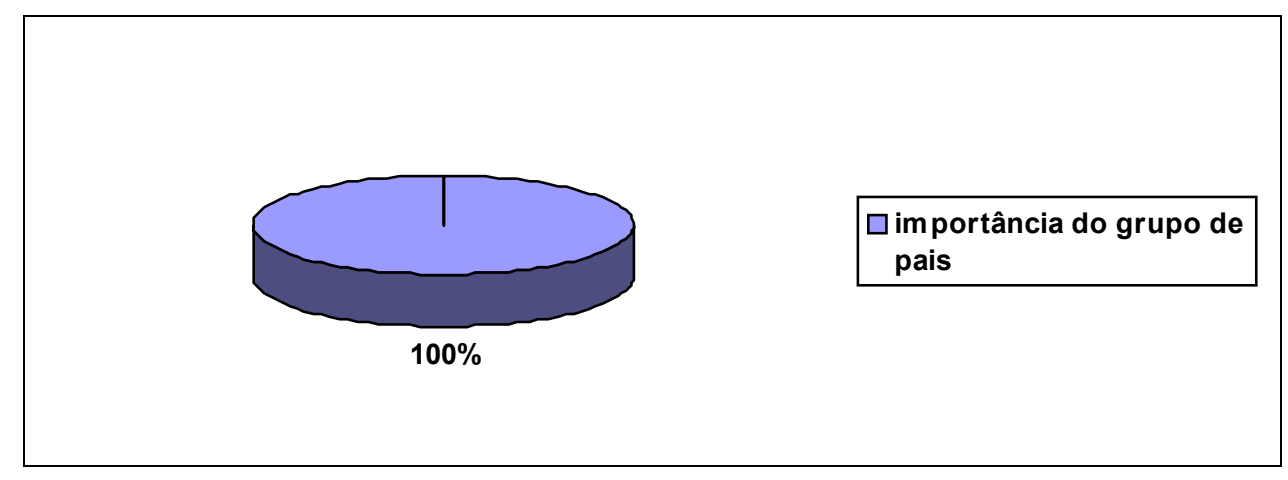

Discurso Coletivo

Quando eu vim para cá, eu não sabia que tinham essas reuniões, eu até comentava com o pessoal do serviço que sempre tem atendimento para os surdos, para os filhos, mas não tem para os pais.

Eu dou muito valor para as reuniões do grupo de pais. Nós temos a nossa família, nossa esposa, filhos, mas aqui, de $4^{a}$ feira é uma família mesmo.

As reuniões são importantíssimas porque é onde a gente coloca as dificuldades e a gente vê as dificuldades dos outros, então a gente fala: -não é tudo isso que a gente pensa. Acho que um ajudando o outro, isso é muito importante. A troca de informações, a gente fica ouvindo e querendo ou não acaba assimilando alguma coisa que uma outra pessoa fala. Te serve de ajuda, 
de apoio. Você sabe que não está sozinho, tem outras pessoas que passam pela mesma coisa. Tem uns que tem filhos com mais idade e você já pega alguma coisa e fala que lá na frente vai precisar disso, ou daqui a pouco eu vou usar. A gente acaba tirando muitas dúvidas, até mesmo entre os pais pois um esclarece uma coisa, outro esclarece outra e isso vai te fortalecendo porque você vê que não é tudo isso, é bem mais fácil.

Para quem está começando, é aquele incentivo, é tudo o que a gente precisa na hora. Eu aprendi muito e eu acho que cada pessoa, com sua história, traz um pouco de força para gente. Eu acho que cheguei meio baleada e consegui estar do jeito que eu estou hoje devido ao grupo. Se não fossem essas reuniões, eu estaria um monstro até hoje com ele.

Acho que seria legal se a família inteira participasse, se todas as pessoas da minha família viessem aqui na reunião e vissem como que é a vida do surdo, que vissem como é a comunidade, como uma pessoa surda é, acho que não iria ter tanto preconceito da família, pois todo mundo iria aceitar, iria aprender a Língua de Sinais e iria começar a gostar dessa comunidade, da Língua de Sinais, de tudo. Se não fossem as reuniões, eu não iria ser quem eu sou.

Comentário

Quando a gente está há muito tempo, a gente começa achar que já é besteira, vai passando o tempo e a gente está vendo que já viu isso mais de mil vezes. 


\section{Questão 15 do Grupo Indireto}

Como você avalia as reuniões do grupo de pais?

Gráfico 5.15 - \% das respostas dadas a questão 15 pelo Grupo Indireto

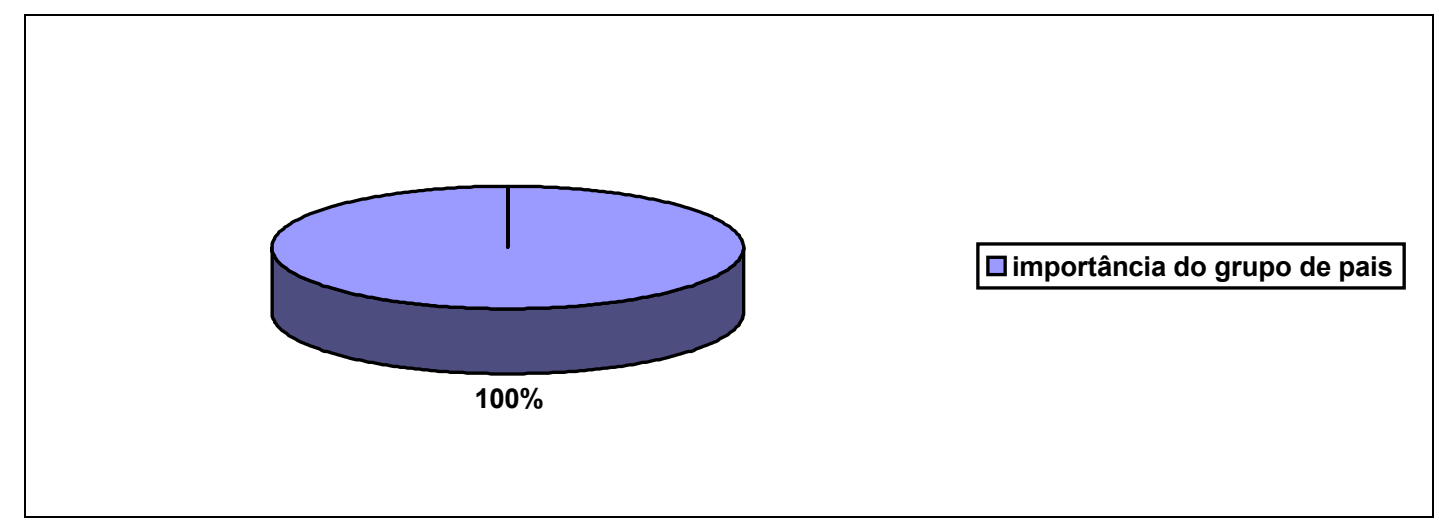

Discurso Coletivo

As reuniões do grupo de pais são muito boas porque são experiências que a gente realmente passou, quase todas parecidas. Às vezes a gente não acredita no começo, depois a gente aprende. A gente vê um monte de gente, cada um fala do seu problema e a gente aceita e vai se integrando no dia a dia da criança.

É muito bom expor, conversar, trocar informações e assim, um vai ajudando o outro, vai dando idéia, vai comunicando, vai se entendendo. É muito importante a amizade aqui e a gente em casa vai procurar conviver melhor com a criança. A vida está muito corrida e quando a gente se encontra para discutir, para tentar encontrar uma solução para alguma coisa ou ajudar de alguma forma, eu acho importante. E tudo isso vai enriquecendo, vai fazendo com que a pessoa consiga saber lidar com os momentos novos que surgem, as dúvidas vão se esclarecendo devagar. 
É bom, também, para o psicológico dos pais, pois um se abre para o outro, não fica aquela idéia de que porque meu filho é surdo, ele não consegue fazer isso, não consegue fazer aquilo. Aqui eles vêem que não é só o próprio filho que tem esse problema, outras crianças também tem e muitos pais convivem com isso muito bem.

O pessoal é muito comunicativo, sempre procurando ajudar o outro, apoiando. Eu ficava meio assim, porque a gente, no começo, não aceita e acho que tivemos muito apoio dos pais. $E$ eu acho que essas reuniões são, justamente, muito boas porque aqui nós podemos discutir algumas coisas e levar para vocês:- olha, eu acho que não está legal, vamos tentar mudar? O que vocês acham de mudanças?

\section{Questão 16 do Grupo Direto}

Você conversa com as outras pessoas da casa sobre o que foi discutido no grupo?

Gráfico 5.16 - \% das respostas dadas a questão 16 pelo Grupo Direto

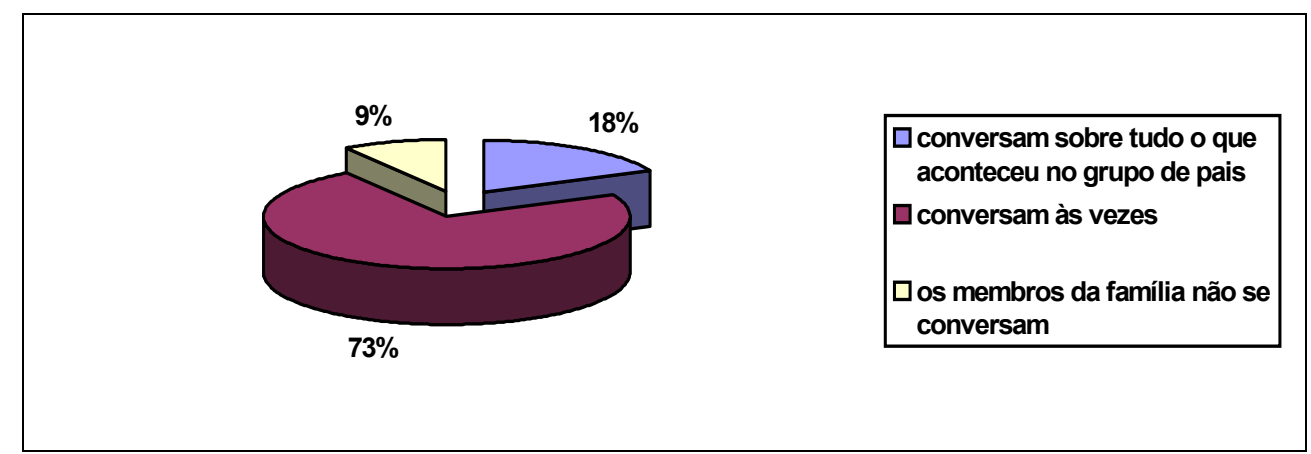




\section{Discurso Coletivo 1}

Em casa eu converso tudo com ele. Eu converso, foi passado isso, assim. Quando eu não venho, eu pergunto tudo e ele também é a mesma coisa e a gente também discute sobre tudo.

\section{Discurso Coletivo 2}

Na maioria das vezes eu converso com ele sobre as coisas que aconteceram no grupo. Geralmente a gente conversa, o que se passou, o que não passou, como é que estava o grupo, mas ele é muito desligado, está de frente para a televisão, e eu estou falando, às vezes ele está quase dormindo. Eu não passo tudo porque às vezes é muito corrido, mas se tem alguma coisa interessante, eu já chego falando para ele. Se ele pudesse vir um dia ou uma vez no mês, eu acho que seria mais aproveitado.

Às vezes eu quero falar com os outros em casa, mas eles me cortam, então acabo não conversando. Só, às vezes, com a minha mãe, que é quem mais pergunta e a minha sogra, ou quando é um assunto que chama atenção deles, aí eles ficam entretidos.

Comentário individual

"Com ela não, é muito difícil, a gente não tem um bom diálogo, a gente não tem diálogo. Não adianta a gente chegar aqui pra mentir. Tem que dizer a realidade. E não é com mentira que eu vou te convencer. Acho que ela que tem que se convencer que precisa estudar." 


\section{Questão 16 do Grupo Indireto}

Você conversa com as outras pessoas da casa sobre o que foi discutido no grupo?

Indireto

Gráfico 5.17 - \% das respostas dadas a questão 16 pelo Grupo

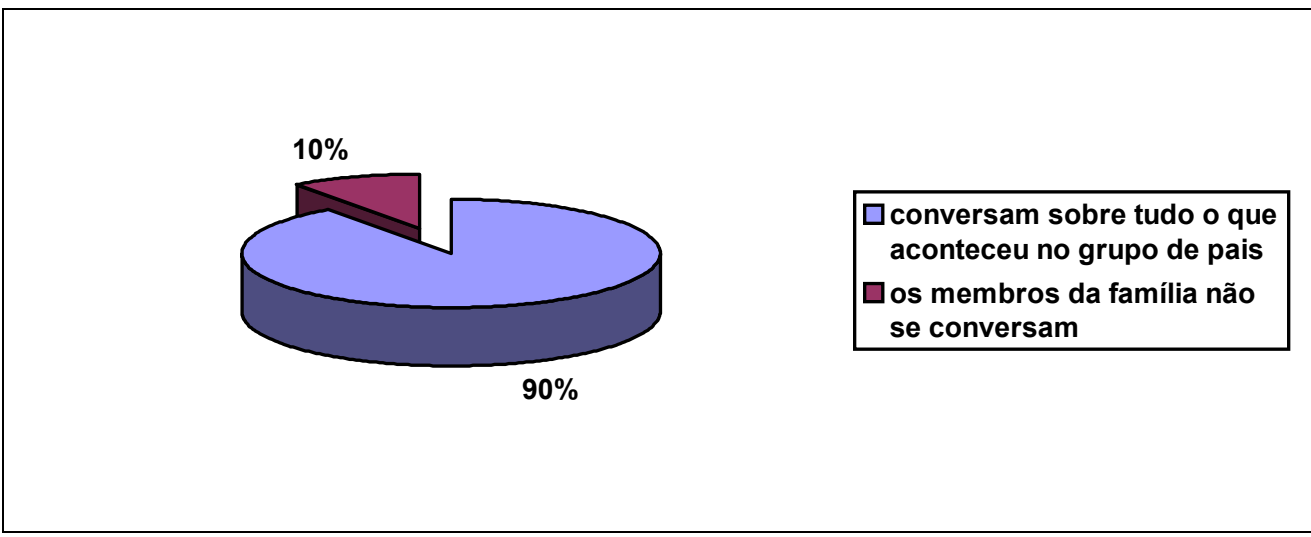

Discurso Coletivo

Eu peço que ele me fale tudo e quando ele chega, ele já me fala. Ele conversa comigo sempre. Conversa sobre todas as coisas que acontecem ou pelo menos as principais e eu fico a par do que está acontecendo. Ele fala das palestras, dos encontros que tem e ele passa também um pouco dos sinais para gente. A casa é cheia de papel que ele enche lá e ele me manda estudar para aprender a letra e o sinal.

\section{Comentário}

"Eu não converso com o meu pai, eu não falo com ele, mas assim quando é alguma coisa para passar, ele passa. Quando vai acontecer uma 
coisa, ele fala, tudo ele passa. A gente não tem uma convivência de conversar, como a gente está conversando, mas tudo o que tem, que acontece, tudo o que tem que ser passado, ele passa."

\section{Questão 17 do Grupo Direto}

Mudou alguma coisa na sua família depois que iniciou tratamento no laboratório?

Gráfico 5.18 - \% das respostas dadas a questão 17 pelo Grupo Direto

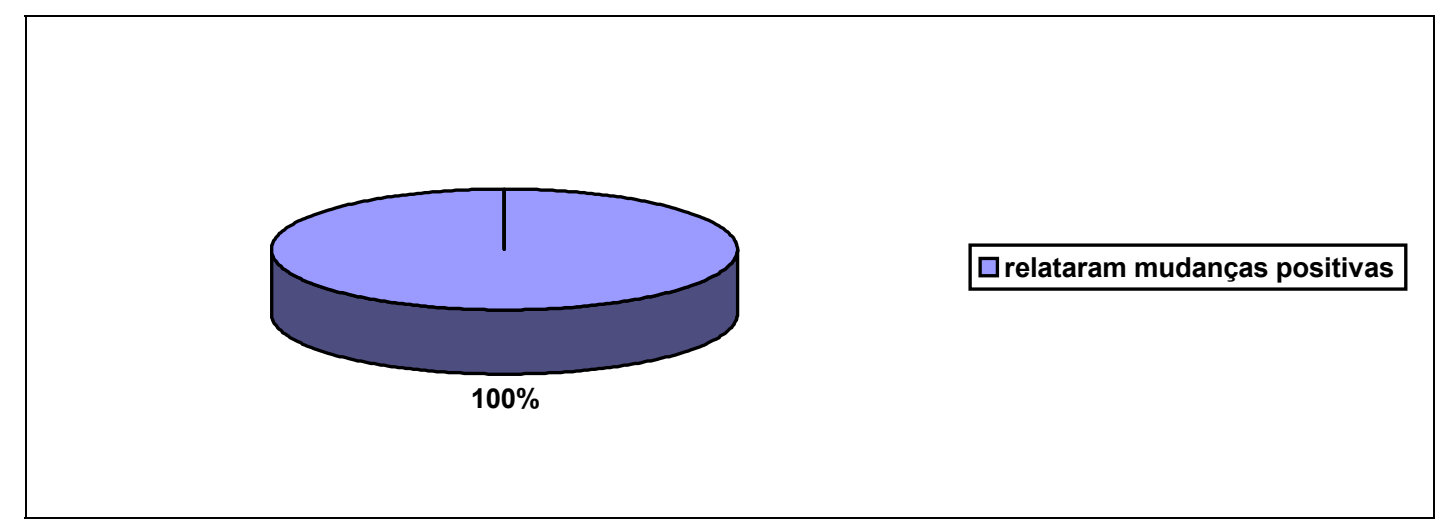

Discurso Coletivo

Depois que entramos aqui mudou tudo. Mudou a visão que se tem em relação aos outros surdos. De que eles são só surdos, mas que podem viver naturalmente e que precisam realmente de sinais. Mudou em relação até preconceito mesmo, porque eu via o preconceito das pessoas em relação ao meu filho surdo achando que ele era um doente mental ou que a surdez era uma doença. O nosso relacionamento ficou mais calmo, estava muito perturbado, muito agitado porque tanto ele como nós éramos nervosos. 
Mudou, também, o jeito da gente se comunicar. A nossa comunicação melhorou, ficou outra, hoje ficou bem mais fácil e a gente se entende melhor. Hoje ele fala muito mais coisas do que ele falava. É lógico que é um processo longo, não é de agora, já está vindo há muito tempo. Hoje ele é uma pessoa meiga e educada.

\section{Questão 17 do Grupo Indireto}

Mudou alguma coisa na sua família depois que iniciou tratamento no laboratório?

Gráfico 5.19 - \% das respostas dadas a questão 17 pelo Grupo Indireto

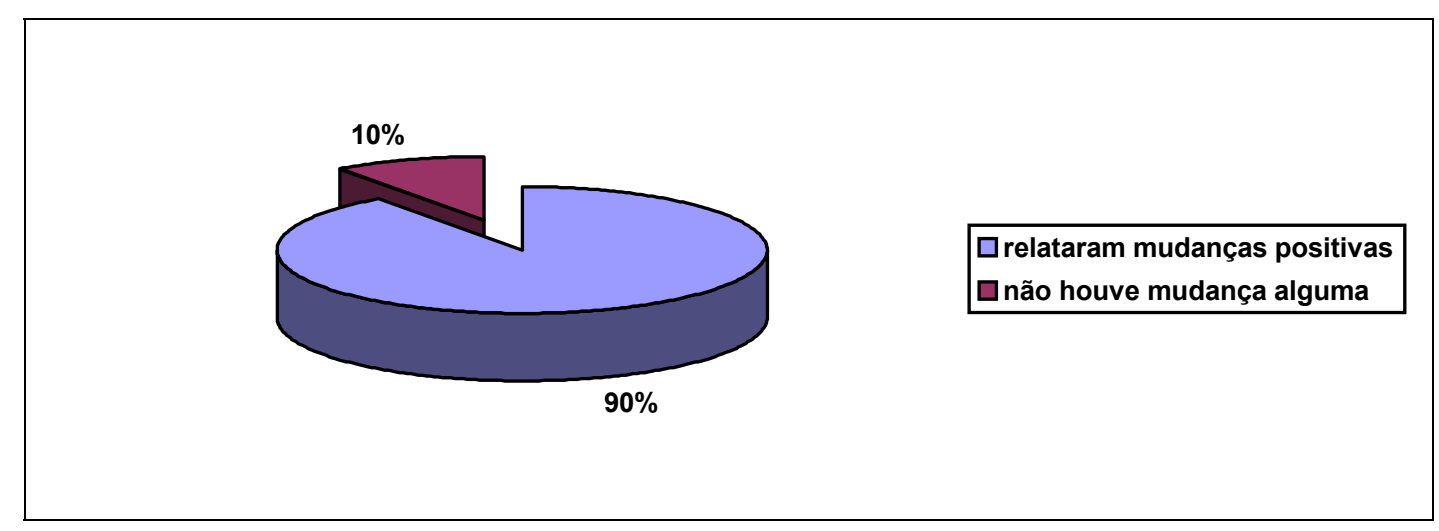

Discurso Coletivo

Em casa o que mudou, desde o início do tratamento, foi a dinâmica, o relacionamento entre a gente, a aceitação da surdez e o entendimento de como vai ser o futuro dele, porque foi aqui que ele começou. Ele vem aqui e já vai com aquilo para gente discutir em casa. Através dos sinais a gente está se comunicando com ele. 


\section{Comentário}

"Em casa não mudou nada desde que a Helena começou tratamento aqui, tudo continua a mesma coisa."

\section{Questão 18 do Grupo Direto}

Hoje, quais são as suas expectativas?

Essa questão envolve as expectativas que a família tem para a vida de suas crianças surdas. São expectativas muito particulares de cada uma dessas famílias e por isso, resolveu-se deixá-las como estão, sem transformá-las em um Discurso do Sujeito Coletivo. O que elas têm como idéias centrais são as preocupações em relação à independência das crianças surdas no futuro, em relação a vontade de que seus filhos venham a falar e em relação à escolaridade.

"Hoje eu só quero que a Ana fale, não por mim, porque por mim está ótimo, mas pela sociedade. A sociedade é preconceituosa, e se a Ana não falar, pelo menos não conseguir perguntar onde é tal coisa, entender o que os outros falam, como a professora surda de Língua de Sinais que é uma pessoa que fala, que lê lábios e consegue se comunicar com qualquer um, tanto surdo como ouvinte. E é o que eu queria que a Ana fosse, uma pessoa como a professora surda, para ela conseguir viver, arrumar emprego, trabalhar e ser uma pessoa normal, só com um probleminha, é isso que eu queria." 
"Hoje o que eu espero é que ele fale, mas não daquela maneira forçada, e que ele seja um menino normal. Que ele possa pegar um ônibus sozinho, que ele possa vir no grupo, assim adulto mesmo, sabendo das coisas. Hoje minha expectativa é essa, que ele progrida, que ele fale, que ele fique bem nos sinais mesmo, e que acabe esse preconceito, porque às vezes até ele mesmo tem vergonha dependendo da atitude que ele toma. Então eu falo que ele é surdo, aí ele acalma, então ele já está entendendo, tendo essa consciência. E um ajuda o outro, então a minha expectativa é essa, que ele progrida, não sei se ele vai falar bem ou não, mas que nos sinais ele já está bom, ele está.“

"Hoje o que eu espero é que ele melhore cada vez mais, eu acho que ele tem um potencial grande, ele gosta de ouvir, pelo menos ele gosta de usar o aparelho, porque a gente percebe. Eu acho que a minha expectativa é só aumentar cada vez mais a fala dele.“

"Hoje eu espero que continue como sempre. Que graças a Deus sempre fui bem atendida aqui. Quando ela começou a aprender a língua dela, a brincar, como brincar, o que eu peço e agradeço sempre é que foi desde aqui que a gente começou, e continua aprendendo. E eu quero que continue. Eu só tenho a agradecer, agradecer, agradecer sempre, sempre.“

"Hoje as minhas expectativas é que eu acho que o Eduardo ainda tem chances de evoluir bastante, a começar até a falar, porque ele já faz bastantes 
sonzinhos. O meu ponto de vista é que ele evolua bastante para facilitar a vida."

"Hoje, eu não estou fazendo muitas expectativas. Ontem ela veio com uma história com o cobrador do ônibus, falando para ele que ela sabe mexer naquele negócio de dinheiro e que ela ia trabalhar naquilo lá. Eu achei interessante, não sei se é isso que eu quero para ela, mas vai ser uma coisa que ela vai se decidir. (...) Agora minha expectativa maior é dela aprender logo a ler e escrever, eu estou esperando um pouco ansiosa, estou com um pouco de medo de demorar muito, mas acho que é devagar mesmo."

"Hoje eu nem sei te dizer quais são as minhas expectativas. Eu espero que ele seja um bom menino. Ele fala que vai estudar, vai trabalhar com computador, fazer curso de computador e vai trabalhar para ter muito dinheiro. Ele fala isso, que vai casar com uma menina. Uma menina, para ele casar quando estiver homem e tiver muito dinheiro. $\mathrm{E}$ ainda fala que quer ter dois filhos. Eu acho interessante e quando perguntei o porque, ele disse que todo homem tem filho. Acho interessante isso que ele fala.“

"Hoje eu espero, agora que eu já sei como vai ser a vida dela, estou fazendo de tudo, para ela crescer, depender dela, ter um trabalho legal, estudar, ter a vida dela sem depender de mim mais tarde, como qualquer um de nós, eu espero isso dela.“ 
"Às vezes eu fico pensando, será que ela vai crescer, vai poder trabalhar amanhã ou depois... A gente fica na dúvida, mas a esperança é isso. Ela fala que vai trabalhar quando crescer. Que vai trabalhar, ganhar dinheiro e comprar um carro (fez sinal de comprar carro). É ela fala bastante isso, vamos esperar."

"A expectativa é o que estou falando. Eu já coloco a coisa bem lá para frente. É como eu vejo, às vezes saio e vejo uma criança, menino, menina, nos seus 12,13 anos, e eu tenho muito prazer em ver que meu filho está nesse estágio e eu sei que ele vai chegar lá, falta tão pouco, então para isso a gente persiste e vem mesmo. Se for preciso vir a noite, não sei, eu quero ver meu filho da maneira como eu vejo fora, os outros, quero ver ele igual. E eu sei que vai ser sim, condições a gente tem dado. Meu único medo é uma incerteza de não saber se eu vou ou não vou ver meu filho. A cabeça fica meio, então isso dá uma garra, uma vontade de lutar, que eu brigo, brigo mesmo. Jorge é tudo para mim, eu jogo, exponho, jogo ele assim mesmo, é meu filho, e sinto um orgulho."

"Hoje a minha expectativa é de que amanhã ou depois, a Daniela vai se desenvolver cada dia mais, como ela já vem se desenvolvendo. Está bem mais calma, e que ela siga um caminho. A gente tem um compromisso com ela de no próximo ano ajudar muito na questão escolar, porque ela tem que desenvolver, principalmente na escrita e na leitura, para que possa dar uma seqüência na série da escola, para que não fique muito amarrada na escola. 
Existem crianças que ficam dois, três anos no prezinho, no primeiro e a gente não tem vontade que isso aconteça com ela. A gente quer que ela se desenvolva. A gente vai fazer o máximo, ajudar para que ela se desenvolva."

\section{Questão 18 do Grupo Indireto}

Hoje, quais são as suas expectativas?

Assim como no Grupo Direto, as respostas dessa questão não foram transformadas em Discurso do Sujeito Coletivo, por se tratar de expectativas particulares de cada família.

"O que eu espero (...)? Que o Bento leia mais os lábios. Ele é muito agitado, às vezes desatencioso e então que leia os lábios, que solte mais sons porque ele se limita a falar e quando ele fala, ele fala bem, então é isso que eu não entendo. Ele fala vó muito bem, ele fala água, ele fala não perfeitamente e é isso eu fico esperando as outras palavras. O Bento é muito inteligente, não falta nada, assim."

"Hoje eu quero que ela se desenvolva mais, que cresça mais e que não tenha discriminação quando ela estiver maior. Que ela arrume serviço também, porque hoje em dia, um de cadeira de rodas, outro surdo, outro não sei... é muita discriminação para esse pessoal e não pode ser assim. Ela anda, é uma menina com saúde! Ela sabe escrever bem, faz tudo certinho, na escola 
vai muito bem, então, eu quero o melhor pra ela e eu já falei para Célia que pai é aquele que cria, não aquele que põe no mundo."

"Hoje ela está com oito anos e eu vejo, eu sou sempre otimista, eu creio que ela daqui a pouco estará lendo. Ela está começando a falar as palavras e minha expectativa é a melhor possível. Vou te falar porque, até como pai, a gente não pode nunca desanimar, eu não desanimo nunca. Minha expectativa é vê-la estudando em uma escola normal, lutando, fazendo uma faculdade, que meu pai queria me dar e não pode. Mas eu vou tentar fazer o máximo por ela e pelos dois. Dar aquilo que meus pais sempre quiseram me ajudar, mas que pelas dificuldades, por ter vindo da roça, do interior, não conseguiram e eu quero dar para eles o melhor. Quero vê-la uma pessoa normal, fazendo o que ela gosta, procurando sempre incentivar, sempre impondo os limites, porque também a gente tem que dar e saber cobrar responsabilidade da criança. (...), tenho certeza que ela vai se desenvolver e vai falar como nós."

"Hoje eu espero que se veio até aqui, e ela está melhorando cem por cento, eu espero que continue assim. Sempre melhorando cada vez mais, tanto do lado dela quanto do nosso. Se a gente aprender a se comunicar com ela direitinho dentro de casa, vai ser bom de mais."

"Hoje eu espero que, do que depender de mim, é dar todo apoio, toda força, todo apoio que ela precisa para ela continuar desenvolvendo. Eu já vi, 
conheci criança surda que com muita vontade que tem de falar, acaba falando as palavras e a minha intenção é ajudar. Como eu gosto, aprendi a gostar muito dela e ela gosta muito de mim também, tanto é que ela é muito carinhosa, então a minha expectativa é crescer com ela, ela crescendo no tamanho e na inteligência e eu também crescendo, aprendendo com ela."

"Hoje, o que eu quero mais é que ele cresça, que ele consiga estudar, porque eu vejo que hoje em dia, não tem limitações no campo de trabalho. Tudo é questão de estudar. Tem que ter também o esforço dele. Depois ele vai crescendo e o que a gente puder fazer, a gente vai apoiando devagar, para ele não ter problema nenhum. Tem que dar força, não tem outra saída, não adianta você querer abandonar a criança numa hora dessa. Tem que simplesmente dar força."

“Hoje as expectativas são da gente estar aprendendo mais para poder ajudá-la e quebrar esse muro que ainda não está totalmente quebrado. Ainda tem alguma coisinha para gente descobrir do outro lado, para gente poder ajudá-la, eu acho que é isso aí."

"Mas eu espero que coisas boas aconteçam, que ela se desenvolva mais, aprenda a falar." 
"Hoje, o que eu espero, é egoísmo, mas eu espero que a minha filha fale. Que ela aprenda a falar rápido, ou então que domine bastante a Língua de Sinais, espero isso."

"Hoje, minhas expectativas, são de que como ele está com cinco anos e o ano que vem, mais um ano de terapia, desse acompanhamento que está sendo feito e com sete anos eu espero que ele já consiga ir para uma escola para fazer a primeira série, essa é a minha expectativa. Porque a coisa está andando um pouco mais com uma certa velocidade, por ele já estar numa escola da Prefeitura lá em Osasco. (...) Mas enfim, a expectativa é que ele consiga com sete anos começar a primeira série, porque ele já sabe escrever, ele já sabe o abecedário, o nome das letras, ele já sabe fazer algumas contas, então mais um ano ainda ele já vai aprender mais algumas coisas.(...), é essa oportunidade que eu queria para ele. Dele não perder tempo nessa parte."

\subsection{Análise comparativa entre os discursos do Grupo Direto e}

\section{Grupo Indireto}

Os discursos apresentados na questão 9, tanto no Grupo Direto quanto no Grupo Indireto, mostraram que em relação ao uso do AASI, as crianças surdas atendidas no LIFAE têm três tipos de comportamento diferentes: as que usam e gostam do AASI, as que só usam o AASI apenas para ir à escola e às terapias de fonoaudiologia e as que não gostam e não querem usar os 
aparelhos. A análise das textualizações indicou que as crianças que se comunicam através da Língua Oral são as que estão melhor adaptadas ao aparelho. Assim como, a maior parte das crianças que não gosta de usar AASI é porque ainda não se adaptou a ele e não viu sua importância pois consegue se comunicar bem através da Língua de Sinais.

Quando lemos os discursos da questão 10, podemos notar que eles complementaram o que foi dito na questão anterior. Os pais que fazem uso da Língua Oral de maneira mais consistente, sentem diferença na comunicação quando seus filhos estão com ou sem aparelho, pois com o AASI as crianças escutam alguns sons, localizam melhor a fonte sonora e percebem que tem alguém conversando com eles. As famílias que fazem uso das duas línguas concomitantemente dizem que a comunicação não se altera, estejam as crianças surdas com ou sem aparelho. Um entrevistado colocou, ainda, que o AASI pouco ajuda e que a criança se comunica mais quando está sem o aparelho.

Na questão 11 que aborda o como se estabelece a comunicação entre o entrevistado e a criança surda, pode-se verificar a diferença entre os dois grupos entrevistados. No Grupo Direto, os discursos mostraram que alguns se comunicam somente por sinais e outros dizem utilizar a Língua Oral e alguns sinais caso a criança não os entenda, a fim de garantir a comunicação. No Grupo Indireto, os discursos evidenciaram que alguns também fazem uso dos sinais para garantir a comunicação com a criança surda, porém existem 
aqueles que só se comunicam pela Língua Oral e também os que fazem uso dos integrantes do Grupo Direto como intérpretes.

Complementando essa questão, temos a pergunta 13 em que foi questionado como se estabelece a comunicação entre as crianças surdas e os outros membros da família. Quando questionado ao Grupo Direto, os discursos mostraram uma comunicação oral predominante, ou o uso das duas línguas ao mesmo tempo. Nessa questão pode-se observar também o papel de interprete exercido pelos membros desse grupo.

Para que a comunicação se estabeleça existe alguma estratégia? Segundo os participantes do Grupo Direto não existe uma estratégia pré estabelecida, porém eles deram exemplos do que fazem em casa para que seus filhos os entendam: olhar para a criança, fazer desenhos, pedir para mostrar o que quer, fazer mímicas, etc. Nos discursos do Grupo Indireto vemos que alguns pais criaram meios para garantir a comunicação, mas não achavam que isso fosse realmente uma estratégia. Outros disseram que existe sim, uma estratégia e que aprenderam com as situações do dia a dia. Ainda, no relato de um entrevistado, temos que, caso a criança não o entenda, fica por isso mesmo e ele deixa a criança sem saber o que ele queria.

Os discursos apresentados na questão 14, sobre a aceitação da Língua de Sinais mostraram que a maioria dos entrevistados aceita a Língua de Sinais e acredita que ela é muito importante para a comunicação com seus 
filhos surdos. A diferença entre os discursos está no modo como essa aceitação ocorreu. No Grupo Direto, uma parte aceitou a Língua de Sinais de imediato, a outra colocou apenas a dificuldade existente no aprendizado de uma nova língua. No Grupo Indireto, parte mostrou ter tido uma boa aceitação e a outra, apesar de ter aceitado a Língua de Sinais, a aceitou por falta de opção. Ainda nesse Grupo temos um relato no qual o entrevistado ainda não aceita a Língua de Sinais. Mais do que isso, ele ainda não aceita o fato da sua filha ser surda.

Em relação ao Grupo de Suporte aos Pais, todos relataram o quão importante são as reuniões, pois esse é o espaço e o momento em que eles tiram suas dúvidas e colocam seus problemas, angústias, desafios e conquistas. O fato de poderem trocar informações com quem já vivenciou situações semelhantes os fortalece e também os incentiva a superar as dificuldades.

No Grupo Direto houve, ainda, um comentário de um familiar dizendo que apesar de saber o quão benéfico foi para ele e para sua família, a participação no Grupo de Suporte aos Pais, ele sente que depois de um certo tempo as reuniões não são assim tão relevantes: "Quanto às reuniões do Grupo de Pais, no meu ponto de vista é bom porque quando a gente está há muito tempo, a gente começa a achar que já é besteira, mas no começo, para quem está começando, é aquele incentivo, é tudo o que a gente precisa na hora." 
Em relação à pergunta 16 que diz respeito à troca de informações em casa, os participantes e seus familiares disseram que na maioria das vezes conversam sobre o que aconteceu durante as reuniões do Grupo de Suporte aos Pais. Essas conversas não são sistemáticas, porém eles relataram que passam pelo menos o que é essencial, aos outros membros da família.

A principal diferença entre os discursos dos dois grupos se encontra na vontade que os participantes do Grupo Direto têm de que os outros membros da família participem sistematicamente das reuniões do Grupo de Suporte aos Pais.

Em um caso, os membros da mesma família relataram que não conversam entre si. Essa não comunicação pode gerar a falta de troca de informações e de conhecimentos que beneficiariam a vida da criança surda. Esse fato pode ser complementado pelo resultado da análise de concordância intrafamiliar, pois nesse caso, essa família apresentou apenas $30 \%$ de concordância nas respostas dadas.

A questão 17 mostra as mudanças que ocorreram nas famílias após iniciarem o tratamento fonoaudiológico no LIFAE. As mudanças, na sua maioria, encontraram-se no tipo de relacionamento entre os membros da família graças à aceitação e ao entendimento da surdez e à possibilidade de comunicação com seus filhos surdos. Através da troca de informações e de conhecimento e das oficinas de LIBRAS, a maior parte das famílias aceita a 
surdez e conseqüentemente seu filho surdo. Além disso, as famílias se esforçam para se comunicar com a criança surda e que esta faça parte do dia a dia da família. Apenas um dos entrevistados relatou não ter ocorrido mudança alguma.

Na questão 18 que trata sobre as expectativas futuras, apesar de não ter sido feito um discurso coletivo pois se trata de particularidades de cada família, ainda assim existem idéias em comum. Todos os entrevistados querem que seus filhos se desenvolvam mais para que se tornem independentes e assim, possam ter uma vida normal.

Apesar dos pais aceitarem a Língua de Sinais, como a língua de seus filhos surdos, a maioria ainda quer que eles falem, pois acreditam que assim eles poderão viver inseridos em uma sociedade predominantemente ouvinte.

Outra preocupação é o aprendizado da leitura e escrita, pois isso também é garantia de que as crianças possam se comunicar fora da comunidade surda e que propiciará a elas a oportunidade de inserção no mercado de trabalho, tornando-as pessoas independentes e responsáveis por si mesmas. 
6. Discussão 
É do conhecimento geral que a deficiência auditiva acarreta na criança não apenas alterações no desenvolvimento da linguagem, como também nos aspectos cognitivo, social, emocional e educacional. Portanto quanto mais cedo o diagnóstico for realizado e o processo de intervenção iniciado, melhores serão as possibilidades desta criança desenvolver suas potencialidades (Holzheim, et al., 1997). E a participação da família nesse processo de intervenção é essencial para que algum tipo de sucesso possa ser alcançado, pois é nesse contexto familiar que a criança passa a maior parte do seu tempo e é a família a responsável pelo seu desenvolvimento e pelas escolhas que terá de fazer.

Uma das maiores e principais queixas dos pais e familiares durante as entrevistas recai na demora do diagnóstico, mesmo quando eles próprios já desconfiavam da surdez. Segundo Mahshie (1995) muitos dos que já conversaram com pais de crianças surdas ouviram histórias de como o diagnóstico de surdez foi atrasado pois os profissionais não levaram a sério a preocupação desses pais

Com freqüência, a primeira dúvida dos pais após o diagnóstico da surdez é sobre a aquisição da Língua Oral (Nakamura, et al, 2000). Quando os pais procuram a clínica fonoaudiológica, geralmente buscam um trabalho de desenvolvimento de fala e indicação de AASI, tidos como instrumentos que possibilitam o desenvolvimento oral de seus filhos (Lodi, 2000), assim como atestam os dados obtidos neste estudo. O que se observou é que mesmo com 
a participação em um Programa Bilíngüe como o que é desenvolvido no LIFAE, os pais e familiares ainda continuam com essa expectativa. Eles estão satisfeitos com os progressos, tanto na Língua Oral quanto na Língua de Sinais que cada criança obteve, porém a preocupação com o futuro acaba trazendo a tona a vontade que eles têm de que seus filhos venham a desenvolver a Língua Oral para se tornarem independentes, conseguirem um emprego ou simplesmente para poderem conviver dentro da sociedade ouvinte, majoritária.

A participação do surdo adulto no Programa e seu contato com os pais mostraram ser essencial, como relatou Lichtig et al.(2004c). Vários pais relataram que gostariam que seus filhos fossem como o professor de Língua de Sinais do LIFAE, pois além deste adulto surdo servir como modelo para o futuro dessas crianças, a sua participação ativa no ensino da Língua de Sinais proporcionou, deste modo, o acesso à linguagem e a transmissão natural da identidade e cultura surda (Kozlowski, 2000).

Segundo as informações coletadas, muitas das crianças atendidas no LIFAE usam pouco os AASI em casa ou simplesmente não os usam. Em muitos casos os pais relataram que a criança não gosta e que eles mesmos não sentem muita diferença de quando eles estão ou não usando os aparelhos de amplificação. Às vezes, devido ao alto custo do AASI, os próprios pais tiram os aparelhos das crianças por medo de que estes se quebrem, ou eles mesmos esquecem de colocá-los em seus filhos, deixando de criar, dessa forma, um vínculo positivo e adequado com os aparelhos. A literatura e os 
dados coletados nessa pesquisa indicam que as crianças que se beneficiam com o AASI, normalmente aceitam usá-los. Nos casos em que os pais não acham que os AASI são importantes e portanto não lembram de colocá-los e conseqüentemente não apóiam o seu uso, as crianças poderão ficar acostumadas a não usá-los e terão atitudes negativas em relação a eles (Mahshie, 1995).

Em relação à Língua de Sinais, quando esta passa a ser aceita e usada naturalmente pela família, parece ser um indício significativamente positivo, também, para a aceitação da surdez (Rossi, 2000). Em uma das entrevistas temos um relato que elucida essa afirmação:

"não é bem a língua de sinais que eu não aceito, é mais por ela ser surda. Eu não consigo aceitar, eu não consigo. Eu vejo que pode até ser egoísmo da minha parte, eu sei, mas é tão difícil aceitar que sua filha é surda, é muito difícil. Eu não consigo, não consigo, ainda não aceito."

Ao compararmos as respostas dadas pelos dois Grupos estudados o que podemos observar é um envolvimento maior e uma melhor percepção da vida da criança surda pelos integrantes do Grupo Direto.

A comunicação e interação dos participantes do Grupo Direto com as crianças surdas são mais efetivas, seja por meio da Língua Oral, de Sinais ou das duas línguas ao mesmo tempo. Para eles o importante é que se façam entender. Os participantes do Grupo Indireto como não comparecem à clínica 
ficam menos envolvidos com o aprendizado da Língua de Sinais, delegando a posição de interlocutor aquele que comparece semanalmente, como se fossem intérpretes dessa nova modalidade de língua. Isso mostra o quão benéfico e importantes são as oficinas de LIBRAS disponibilizadas aos pais e familiares ouvintes das crianças surdas atendidas no LIFAE.

A falta de tempo ou de interesse para a troca de informações em casa entre os membros da família, ou a dificuldade em exercer um papel de agente multiplicador, acaba gerando diferenças nos discursos apresentados pelos dois Grupos, como pode ser visto nas temáticas sobre a aceitação da Língua de Sinais, a diferença do relacionamento das crianças surdas com a mãe, o papel de intérprete de alguns participantes e a vontade que os participantes do Grupo Direto têm de que os outros membros da família tenham uma participação mais assídua no processo terapêutico de seus filhos surdos.

Em relação às reuniões do Grupo de Suporte aos Pais do LIFAE, todos os entrevistados, sejam eles do Grupo Direto ou Indireto, acreditam na sua importância, devido às trocas de informações, do Grupo ser um espaço onde eles podem se colocar, de ser um local onde eles podem propor soluções e normatizar os comportamentos de seus filhos, além de fortalecê-los para que tomem decisões e enfrentem dificuldades futuras.

É importante lembrar que o Grupo de Pais do LIFAE procura vivenciar uma abordagem centrada na família, onde é preciso prestar atenção a todos os 
membros e ajudá-los para que expressem suas dúvidas e sentimentos, criando uma parceria de suporte para o aprendizado, crescimento e adaptação na qual a família inteira seja encorajada a participar (Holzheim, et al., 1997). Ao propiciar um ambiente seguro e apoiador e uma orientação que os ajude, os pais e familiares ouvintes poderão ver a sua criança surda de forma positiva, para que possam tomar decisões que levem em conta todo o seu desenvolvimento (Mahshie, 1995).

De acordo com os achados, uma vez que os Discursos apresentados pelos dois Grupos diferem, não no tema, mas na profundidade das informações, seria desejável a participação de todos os familiares no Programa de Intervenção do LIFAE, a fim de que todos tivessem a oportunidade de vivenciar o Grupo de Pais, as oficinas de LIBRAS e de ter contato com outras famílias que passam ou que passaram por situações semelhantes.

Hoje a estrutura que se tem no LIFAE e a realidade das nossas famílias não permite que isso aconteça. É necessário que se faça uma reestruturação na organização do LIFAE, criando novas formas para incluir os outros membros da família no processo terapêutico das crianças surdas, pois o contato com o ambiente é também muito importante. Além disso, é preciso um trabalho no sentido de conscientizar, os participantes diretos do Programa, da importância de se assumir um papel de agente multiplicador, fornecendo ferramentas para que o diálogo e a troca de informações e de conhecimentos adquiridos se torne um hábito. 
Os dados apresentados mostraram que o Programa como está sendo desenvolvido consegue alcançar todos membros da família, porém não com a mesma profundidade, portanto a intervenção fonoaudiológica seria melhor aproveitada se todos os familiares que moram com a criança surda participassem dessa intervenção.

De acordo com as mudanças relatadas, o fato de que a comunicação e a interação familiar se modificou, gerando melhora no relacionamento entre todos os membros da família e na aceitação da surdez, mostra que o caminho traçado pelo LIFAE do Curso de Fonoaudiologia da Faculdade de Medicina da USP está na direção correta e que este modelo de intervenção fonoaudiológica pode ser implementado em outros serviços fonoaudiológicos. 
A participação no Programa de intervenção fonoaudiológica do LIFAE produziu mudanças nos participantes diretos e indiretos do Programa.

A aceitação, com um novo olhar sobre a surdez, e de uma nova modalidade de língua que possibilita a comunicação, ocasionaram mudanças não apenas no comportamento comunicativo de todos os membros, mas também na interação e na dinâmica familiar, melhorando a qualidade de vida dessas famílias.

Quando as famílias mudam seu entendimento sobre a surdez, elas redimensionam de um modo mais abrangente as potencialidades de seus filhos surdos, assim os pais readquirem seu papel de pais e seus poderes de decisão, o que os fortalece, empoderando-os para as escolhas e caminhos futuros a serem trilhados.

O trabalho desenvolvido atesta que este estudo é uma contribuição para área de pesquisa fonoaudiológica e comprova que o Programa desenvolvido pelo LIFAE pode ser proposto como Política Pública no que diz respeito ao atendimento às crianças surdas e seus familiares ouvintes. 
8 Anexo 


\section{HOSPITAL DAS CLINICAS \\ DA FACULOADE DE MEDICINA DA UNIVERSIDADE DE SAO PAULO \\ CAIXA POSTAL, 8091 - SAO PAULO - BRASIL \\ DIRETORIA CLÍNICA}

Comissão de Ética para Análise de Projetos de Pesquisa

\section{APROVAÇÃO}

A Comissão de Ética para Análise de Projetos de Pesquisa - CAPPesq da Diretoria Clínica do Hospital das Clínicas e da Faculdade de Medicina da Universidade de São Paulo, em sessão de 09.04.03, APROVOU - Protocolo de Pesquisa $n^{\circ}$ 114/03, intitulado: "Análise comparativa da intervenção fonoaudiológica na surdez: com a família ou com os pais?" apresentado pela ÁREA DE FISIOPATOLOGIA EXPERIMENTAL, bem como o Termo de Consentimento Livre e Esclarecido.

Pesquisador(a) Responsável: PROFA, DRA. IDA LICHTIG Pesquisador(a) Executante: SRA. RENATA AKIYAMA

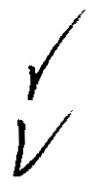

CAPPesq. 09 de Abril de 2003.

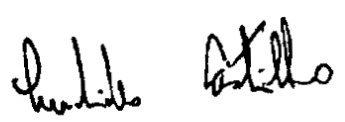

PROF. DR. EUCLIDES AYRES DE CASTILHO

Presidente da Comissão Ética para Análise

Encaninga CPGFMUSP de Projetos de Pesquisa

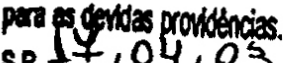

OBSERVAÇÄO: Cabe ao pesquisador elaborar e apresentar à CAPPesq, os relatórios parcials e final sobre a pesquisa (Resoluçäo do Conselho Nacional de saúde $n^{\circ} 196$, de cein fretow

10.10.1996, inciso IX.2, letra "c")

Proi.: Dra. Mana Mitzi Brentant

Coordenadora do Curso de

Pos-Graduacáo do programa

de Fisiopalologra Expermental

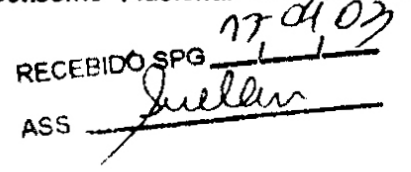


9. Referências Bibliográficas 
AIMARD, P.; (1998) O surgimento da linguagem na criança; Artmed, Porto Alegre; 192p.

BALASUNDARAM, P. (1995) Fostering parental involvement. In: O'TOOLE, B. \& McCONKEY, R. (eds.) Innovations in developing countries for people with disabilities; Lineux Hall Publications, cap3; p. 29

BALIEIRO, C.R. \& FICKER, L.B.; (1997) Reabilitação aural: a clínica fonoaudiológica e o deficiente auditivo. In: LOPES FILHO, O. Tratado de fonoaudiologia; Editora Roca, cap. 15; p. 311.

BERGMAN, L. (2001) Repercussões da surdez na criança, nos pais e suas implicações no tratamento (6 telas). Disponível em http://www.ines.org.br/paginas/revista/TEXTO1.htm.

BUSCAGLIA, L. (1993) Os deficientes e seus pais. Um desafio ao acolhedor. Record; Rio de Janeiro.

CÁRNIO, M.S.; (1998) O papel da família e da escola no processo de leitura e escrita do Surdo. In BAUMEL, R.C.R.C.; SEMEGHINI, I. (org.) Integrar incluir desafio para escola atual; FEUSP, cap. 9; p.117-128.

CÁRNIO, M.S.; GOMES, M.S.; MECCA, F.F.D.N.; COUTO, M.I.V.; LICHTIG, I.; CARVALLO, R.M.M. (2000) Disponibilidade para atividades de leitura e escrita de crianças surdas e ouvintes de 3 a 5 anos de idade. Pró-Fono revista de atualização científica; vol 12 (2): 67 - 72

CÁRNIO, M.S. \& COUTO, M.I.V. (2004) Fundamentos para a intervenção fonoaudiológica em pais de crianças surdas. In: LICHTIG, I. (org) Programa de intervenção fonoaudiológica em famílias de crianças surdas, Barueri, São Paulo; Pró-Fono Editora; p. 1 - 22. 
CARVALLO, R.M.M.; LICHTIG, I.; CÁRNIO, M.S.; COUTO, M.I.V., GOMES, M.S.R.; MECCA, F.F.D.N.; AKIYAMA, R. (2004) Análise qualitativa do programa de intervenção fonoaudiológica em famílias de crianças surdas (PIFFCS). In: LICHTIG, I. (org) Programa de intervenção fonoaudiológica em famílias de crianças surdas, Barueri, São Paulo; Pró-Fono Editora; p165-178.

DAVIS, H. \& RUSHTON, R. (1991) Counseling and supporting parents of children with developmental delay: a research evaluation. Journal of mental deficiency research; vol. 35: 89-112.

DUNST, C.J.; BOYD, K.; TRIVETTE, C.M.; HAMBY, D.W. (2002) Familyoriented program models and professional helpgiving practices. Family relations; vol 51(3): 221-229.

FERNANDES, E.; (2000) Língua de Sinais e desenvolvimento cognitivo de crianças surdas. Espaço; $\mathrm{n}^{\circ}$. 13: $48-51$

FORMIGONI, M.C.L.G. de; (2003) Surdez: uma questão de família (3 telas). Disponível em http://saci.org.br/index.php?modulo=akemi\&parametro=5255.

FUNCK, M.A.O. \& MACHADO, D.M.Z. (1995) Participação da psicologia no atendimento ao portador de deficiência auditiva. Temas sobre desenvolvimento; vol 5(27): 27-32.

GOMES, H.S.R. (1988) Um estudo sobre significado de família. Tese de Doutorado, PUC, SP.

GOMES, J.V. (1992) Família e socialização. Psicologia - USP; vol 3(1/2): 93105.

GOMES, J.V.; (1994) Socialização primária: tarefa familiar? Cadernos de pesquisa. São Paulo, № 91: 54-61. 
GUIMARÃES, R.F.; (1995) Famílias: uma Experiência em grupo. . In: CARVALHO, M.C.B. (org.) A família contemporânea em debate. EDUC, São Paulo; p. 165-179.

HOLZHEIM, D.C.P.M.; LEVY, C.C.A.C.; PATITUCCI, S.P.R.; GIORGI, S.B. (1997) Família e fonoaudiologia: o aprendizado da escuta. In: LOPES FILHO, O. Tratado de fonoaudiologia; Editora Roca, cap. 19; p.415-436.

KELLAM T.L.T. (2001) Filial therapy: a family system intervention. Family therapy; Califórnia; vol. 28(2): 63-71.

KOZLOWSKI, L.; (1998) A proposta bilíngue de educação do surdo. Espaço; $n^{\circ} .10: 47-53$.

KOZLOWSKI, L.; (2000) A educação bilíngüe-bicultural do surdo. In: LACERDA, C.B.F de; NAKAMURA, H.; LIMA, M.C. (orgs) Fonoaudiologia: surdez e abordagem bilíngüe; Plexus Editora Ltda; São Paulo; p.80-98.

LANE, H.; HOFFMEISTER, R.; BAHAN, B. (1996) Families with deaf children. In: A journey into the deaf world; Dawn Sign Press, Califórnia; p.24-41.

LEFEVRE, Fernando \& LEFEVRE, Ana Maria Cavalcanti (2005) O Discurso do sujeito coletivo - Um novo enfoque em pesquisa qualitativa (Desdobramentos) $2^{\mathrm{a}}$ Edição; EDUCS; Caxias do Sul; $256 \mathrm{p}$

LICHTIG, I.; AKIYAMA, R.; COUTO, M.I.V; TARDIVO, L. ; ALTHAUSEN, S.; (2003) Dando voz aos pais ouvintes das crianças surdas. In: Anais do $18^{\circ}$ Encontro internacional de audiologia, sem página.

LICHTIG, I.; CÁRNIO, M.S.; GOMES, M.S.R.; AKIYAMA, R. (2004a) A relevância da participação se surdos adultos no programa de intervenção fonoaudiológica em famílias de crianças surdas (PIFFCS). In: LICHTIG, I. (org) 
Programa de intervenção fonoaudiológica em famílias de crianças surdas, Barueri, São Paulo; Pró-Fono Editora; p. 23 - 38.

LICHTIG, I.; COUTO, M.I.V.; AKIYAMA R.; SLOMSKI, V.; TRETTEL, M. (2004b) Programa transdisciplinar de atendimento a famílias ouvintes e a seus filhos surdos. In: FERREIRA, L.P.; BEFI_LOPES, D.M.; LIMONGI, S.C.O. (orgs) Tratado de fonoaudiologia, Editora Roca; São Paulo; p. 740-750.

LICHTIG, I.; WOLL, B.; CÁRNIO, M.S.; AKIYAMA, R.; GOMES, M. (2004c) Deaf staff members' participation in a Brazilian intervention programme for deaf children and their families: impacts and consequences. Deaf worlds International journal of deaf studies. Vol 20(3):282-298

LIMA, M.C. (2005) O método de pesquisa-ação nas organizações: do horizonte político à dimensão formal. Revista eletrônica de gestão organizacional. Vol 3(2): 141-154. (www.gestaoorg.dca.ufpe.br)

LIMA, R.P.; MAIA, R.; DISTLER S.D.C. (1999) Reflexão sobre um trabalho com famílias. Espaço INES, p.37-39.

LODI, A.C.B. (2000) Educação bilíngüe para surdos. In: LACERDA, C.B.F de; NAKAMURA, H.; LIMA, M.C. (orgs) Fonoaudiologia: surdez e abordagem bilíngüe; Plexus Editora Ltda; São Paulo; p.60-79.

LUTERMAN, D. (1999) Counseling families with a hearing impaired child. Otolaryngologic clinics of North America. Vol. 32 (6): 1037 - 1050.

MAHSHIE, S.N.; (1995) Educating deaf children bilingually. Gallaudet University Pre-College Programs; 262 p. 
MASON, C. (1991) School experience. In: TAYLOR, G. \& BISHOP, J. (eds.) The experience of deafness; Open University, chapter 9, p. 84-87.

MECCA, F.D.N.; GOMES, M.S.R.; AKIYAMA R. (2004) Atuando com a família de crianças surdas. In: LICHTIG, I. (org) Programa de intervenção fonoaudiológica em famílias de crianças surdas, Barueri, São Paulo; Pró-Fono Editora; p. 81 - 110.

MELLO, S.L. de; (2002) Família, uma incógnita familiar. In: AGOSTINHO, M.L. \& SANCHEZ, T.M. (orgs.) Família: conflitos, reflexões e intervenções; Casa do Psicólogo, p. 15.

MEIHY, J.S.B. (1998) Manual de história oral; Editora Loiola, p 29 - 33

MOURA, M.C.; LODI, A.C.B. \& HARRISON, K.M. P.; (1997) História e educação: o surdo, a oralidade e o uso de sinais. In: LOPES FILHO, O. Tratado de fonoaudiologia; Editora Roca, cap. 16; p. 327-357.

NAKAMURA, H.Y.; LIMA, M.C.M.P.; GONÇALVES, V.M.G. (2000) Ambulatórios de neuropsicodiagnóstico da surdez: papel da equipe interdisciplinar. In: LACERDA, C.B.F.; NAKAMURA, H.Y.; LIMA, M.C.M.P. (orgs.) Fonoaudiologia: surdez e abordagem bilíngüe; Plexus Editora Ltda; São Paulo; p.103-113.

O'BRIEN, P.J. (2002) Reflections for a parent support group in an adolescent in patient psychiatric program. Family therapy; vol 29(3): 141-152.

PEREIRA, M.C.da C. (2000) A Língua de Sinais na educação de surdos. In: LACERDA, C.B.F de; NAKAMURA, H.; LIMA, M.C. (orgs) Fonoaudiologia: surdez e abordagem bilíngüe; Plexus Editora Ltda; São Paulo; p. 13-20. 
QUADROS, R.M.; (1997) Educação de surdos - A aquisição da linguagem; Artes Médicas, Porto Alegre; 126p.

RAVAZZOLA, M.C.; BARILARI, S.; MAZIERES, G.: (1997) A família como grupo e o grupo como família. In: ZIMERMAN, D.E. \& OSÓRIO, L.C. Como trabalhamos com grupos. Artmed, cap26, p. 293-304.

RIBEIRO, O.M.(2000) Por que investir em pesquisa qualitativa? Revista brasileira de estudos pedagógicos. Vol 81(197): 109-115.

RITCHIE, J.; SPENCER, L.; (1994) Qualitative data analysis for applied policy research. In: BRYMAN, A; BURGESS, R Analyzing qualitative data; Routhedge, chapter 9; page 173-194.

ROSLYNG-JENSEN, A.M.A.; (1997) Importância do diagnóstico precoce na deficiência auditiva. In: LOPES FILHO, O. Tratado de fonoaudiologia; Editora Roca, cap. 14; p. 297-309.

ROSSI, T.R.de F. (2000) Um processo em direção ao bilingüismo. In: LACERDA, C.B.F de; NAKAMURA, H.; LIMA, M.C. (orgs) Fonoaudiologia: surdez e abordagem bilíngüe; Plexus Editora Ltda; São Paulo; p. 99-101

SÁNCHEZ, C.; (1993) Vida para os surdos [Entrevista]. Nova escola; ano III; $n^{\circ}$. 69: $32-37$.

SKOGMO, P.; (1995) Fostering the formation of parent's association. In: O'TOOLE, B. \& McCONKEY, R. (eds.) Innovations in developing countries for people with disabilities; Lineux Hall Publications, cap9; p. 121.

SOUZA, M.C.F.; WIESELBERG, M.B.; (1997) Aconselhamento em audiologia. In: LOPES FILHO, O. Tratado de fonoaudiologia; Editora Roca, São Pauli; $p$. 587-604. 
SOUZA, M.L. \& GOMES, W.B. (2003) Evidência e interpretação em pesquisa: as relações entre qualidades e quantidades. Psicologia em estudo. Maringá. Vol 8 (2): 83-92.

SZYMANSKI, H.; (1995) Teoria e "teorias" de famílias. In: CARVALHO, M.C.B. (org.) A família contemporânea em debate. EDUC, São Paulo; p. 23-27.

SZYMANSKI, H.; (2000) A família como um lócus educacional: perspectivas para um trabalho psicoeducacional. Revista brasileira de estudos pedagógicos. Brasília, V.81 (197): 14-25.

SZYMANSKI, H.; (2001) A relação família / escola desafios e perspectivas. Plano Editora Ltda, Brasília; 96p.

SZYMANSKI, H.; (2002) Entrevista reflexiva: um olhar psicológico sobre a entrevista em pesquisa. In: SZYMANSKI, H. (org.) A entrevista na pesquisa em educação: a prática reflexiva. PLANO, Brasília; p. 9-61.

TARDIVO, L.S. de L.P.C.; MEDINA, S.K.A.; CARNIO, M.S.; LICHTIG, I.; COUTO, M.I.V.(1999). A utilização de procedimento de desenhos - estórias no estudo dos psicodinamismos de portadores de deficiência auditiva. Anais do VIII Congresso de avaliação psicológica: desafios para um novo milênio. Porto Alegre; p. 104-114.

VITALE, M.A.F.; (1995) Socialização e família: uma Análise intergeracional; In: CARVALHO, M.C.B. (org.) A família contemporânea em debate. EDUC, São Paulo; p.89-96. 
WOLL, B.; WIRZ, S.; LICHTIG, I.; (1995) Programa de atendimento a pais de crianças portadoras de deficiência auditiva com e sem linguagem oral; Projeto de pesquisa apresentado e subvencionado pela FAPESP, CNPq e Conselho Britânico.

ZIMERMAN, D.E.; (1997) Fundamentos teóricos. In: ZIMERMAN, D.E., OSORIO, L.C. (et.al) Como trabalhamos com grupos; Artmed, Porto Alegre, p. 23-31. 